\title{
AMBIGUITY AND IRRECONCILABILITY: \\ A CRITICAL LOOK AT RECONCILIATION DISCOURSE IN FEDERAL LAND CLAIMS AND SELF-GOVERNMENT POLITICAL COMMUNICATIONS
}

\author{
by \\ Rebecca Katherine Hume, Bachelor of Arts in Human Rights and Global Studies, \\ University of Winnipeg, June 2016
}

A thesis presented to Ryerson University and York University

in partial fulfillment of the requirements for the degree of

Master of Arts in the program of Communication and Culture

Toronto, Ontario, Canada, 2020

(C) Rebecca Hume, 2020 


\section{AUTHOR'S DECLARATION FOR ELECTRONIC SUBMISSION OF A THESIS}

I hereby declare that I am the sole author of this thesis. This is a true copy of the thesis, including any required final revisions, as accepted by my examiners.

I authorize Ryerson University to lend this thesis to other institutions or individuals for the purpose of scholarly research.

I further authorize Ryerson University to reproduce this thesis by photocopying or by other means, in total or in part, at the request of other institutions or individuals for the purpose of scholarly research.

I understand that my thesis may be made electronically available to the public. 


\section{Ambiguity and Irreconcilability: A Critical Look at Reconciliation Discourse in Federal Land Claims and Self-Government Political Communications}

Rebecca Hume, Master of Arts in Communication \& Culture

Ryerson University and York University, 2020

Can reconciliation be meaningful when it is at once a journey, a path, a milestone, a framework, a tool of economic development, a spirit, and a process? In this thesis, I use a multimethod approach to problematize how reconciliation discourse is employed ambiguously in both policy and practice in order to maintain settler colonial occupation of stolen Indigenous lands. I first conduct a policy review of federal land claims and self-government frameworks before turning to a Critical Discourse Analysis of public communications to illustrate the limitations of these state-led processes of reconciliation. My analysis elucidates the ways in which these processes are instantiations of settler governmentality that continue to exist as common sense (Rifkin, 2013) within a discursive framework of state-led reconciliation politics. As such, my work demonstrates that in order to work towards the bigger project of decolonization and resurgence, reconciliation must move from purely aspirational terms to substantive, treaty-based responsibilities with the repatriation of Indigenous land as its overarching, incommensurable purpose.

Keywords: reconciliation politics; settler colonialism; Crown-Indigenous relations; critical policy studies; critical discourse analysis. 


\section{Acknowledgements}

I would like to start by acknowledging that my existence on these lands is a consequence of centuries of colonial occupation. As a settler, I benefit from and am complicit in these ongoing violences; thus, the knowledge reflected in this work is a direct result of this privilege.

It is hard to put into words my gratitude. I could not have achieved this project alone.

I will first thank my family: my mom, my dad, my gramma, my grandpa, and my uncle. Your unwavering support has helped me when I most needed it. Mom, thank you for always being my sounding board, my first reader, and my number one fan. You inspire me every single day.

Thank you to my friends back home. You remind me that I am loved even when I am far away.

To my ComCult cohort: we got through this together. Your intellect and humour motivated me to persevere even on the most challenging days. 


\section{Table of Contents}

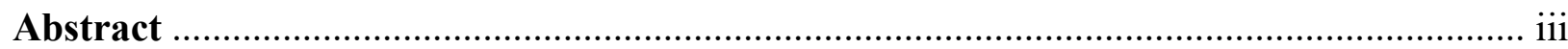

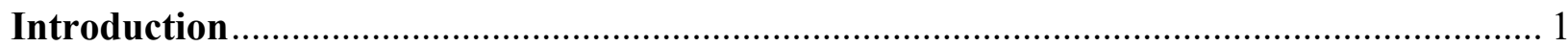

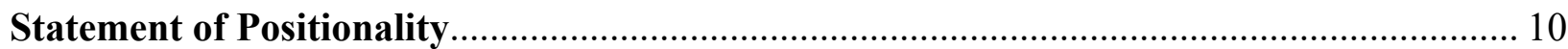

\section{Chapter 1}

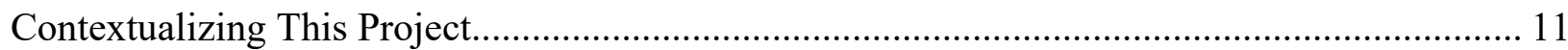

Settler Colonialism as a Central and Pervasive Logic in Canada ....................................... 11

Decolonization as Imperative to This Work ................................................................... 16

INAC as an Instantiation of Settler Colonial Governmentality in Canada ............................. 19

\section{Chapter 2}

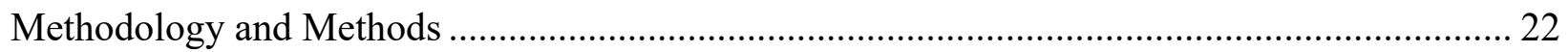

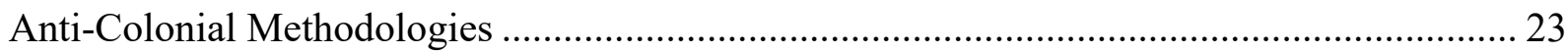

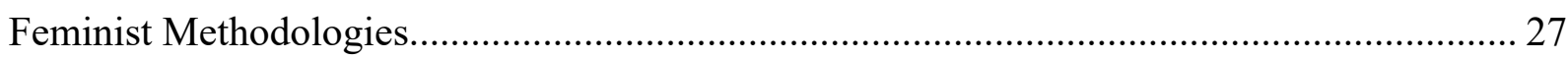

Critical Communications and Policy Review ................................................................. 30

Methods for Critical Discourse Analysis ...................................................................... 35

\section{Chapter 3}

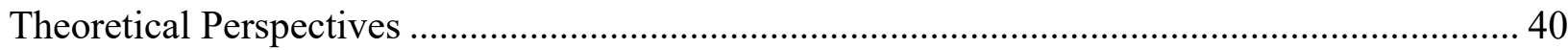

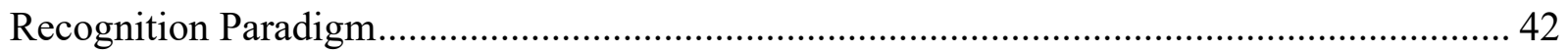

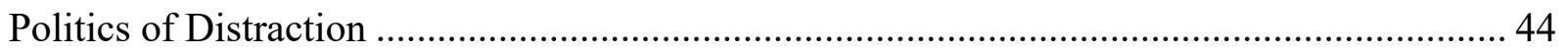

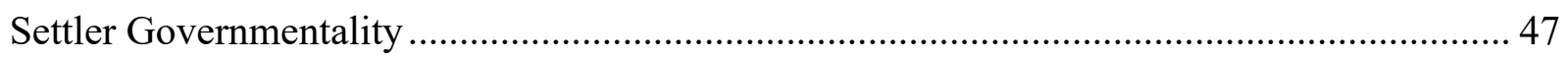

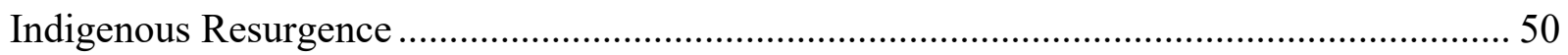

\section{Chapter 4}

Reconciliation as a Shape-Shifting Concept of Colonialism ................................................... 54

A Brief Overview of the Concept of Reconciliation in Canada ........................................... 55

A Review of Critical Literatures in Reconciliation Discourse .......................................... 61

\section{Chapter 5}

Land Claims Settlements and Self-government Agreements as Frameworks of Occupation ...... 68

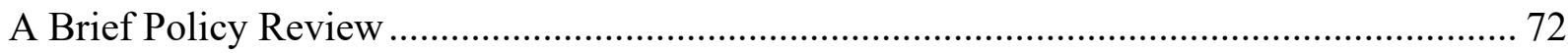

Theme 1: Certainty and Extinguishment as Central Tenets of Agreements ........................... 80

Theme 2: Agreements as Manifestations of Absolute Crown Authority............................... 85

Theme 3: Historicizing Colonialism in Agreements ........................................................ 91

\section{Conclusion}

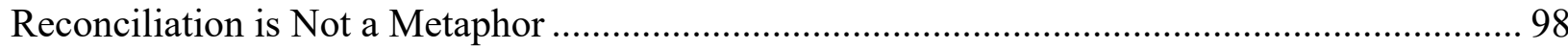

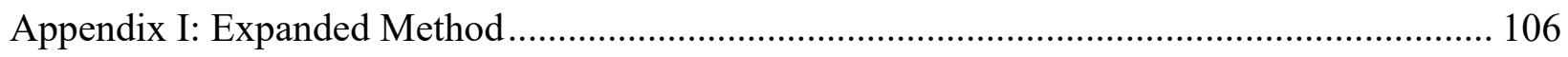




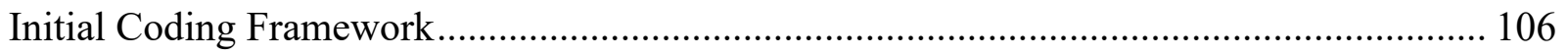

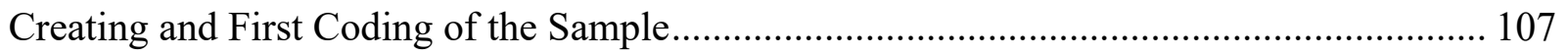

Appendix II: Sample of News Releases from Indigenous and Northern Affairs Canada .......... 112

On Land Claims Settlements …………………………............................................... 112

On Self-government Agreements ................................................................................. 114

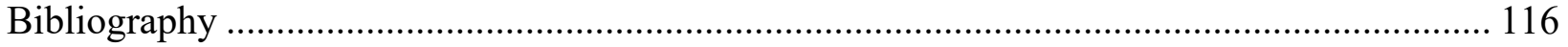


Ambiguity and Irreconcilability: A Critical Look at Reconciliation Discourse in Federal Land Claims and Self-Government Political Communications

\section{Introduction}

In July 2019, Canadian Prime Minister Justin Trudeau urged Canadians to be "patient and unconditional in their support of Indigenous communities on the road to reconciliation and allow them to make mistakes" (Smart, 2019). This kind of political messaging is consistent with the progressive image that Trudeau and his Liberal government has worked tirelessly to construct and maintain since first being elected in 2015. Despite claiming that "no relationship is more important to [him] and to Canada than the one with Indigenous Peoples" (Minister of CrownIndigenous Relations and Northern Affairs Mandate Letter, 2017), many have accused Trudeau of consistently demonstrating not only smug condescension, as exemplified in the quote above, but outright callousness and disdain toward Indigenous peoples through countless insidious legal challenges and destructive policy decisions. One particularly telling example of the Trudeau government's priorities occurred in September 2019 when the Liberals announced that they would be challenging a landmark Canadian Human Rights Tribunal decision that had recently ordered the state compensate over 50,000 First Nations survivors of the federal on-reserve child welfare system (Stefanovich, 2019). It is no surprise, then, that patience for Trudeau and his lofty rhetoric is running out. Months earlier, in a response to the Liberal government's purchase of the highly controversial Trans Mountain pipeline project on unceded Indigenous territory in British Columbia, Eeyou New Democrat Member of Parliament Romeo Saganash stood up in the House of Commons and stated that Justin Trudeau "doesn't give a fuck about the rights [of Indigenous peoples]" (Cecco, 2018). This starkly contrasts Trudeau's era of reconciliation and vision for 'renewed nation-to-nation relationships' between the Crown and Indigenous peoples in Canada, and highlights the extent to which this aspirational rhetoric is woefully inadequate in addressing 
historical and ongoing colonial violence. In this thesis, I pause and reflect: what exactly does this state-led vision for reconciliation entail, and who truly stands to benefit from it?

As non-Indigenous scholar Jaskiran Dhillon (2017) highlights, the recent political push for reconciliation can be read as merely an attempt to reconstruct the face of settler colonialism in Canada into a less-overtly assimilatory state agenda. Importantly, reconciliation as a political undertaking fails to substantively address the structures of violence and dispossession inherent to Canadian constitutionalism and in doing so, upholds and further entrenches settler governmentality through recognition and participation within the Canadian political system. I understand reconciliation as a product of hegemonic settler colonialism, which unequivocally validates the continued theft of Indigenous land and is therefore intricately tied to capitalism. Settler states like Canada cannot exist if they do not have access to land and thus settler futurity ${ }^{1}$ depends on ongoing occupation. Yet, this continued occupation is fundamentally based on the international legal principle terra nullius, which was used by early settlers to facilitate the theft of land by claiming they were empty. The lands were not empty, and thus the continued settler occupation in Canada is problematic and illegal ${ }^{2}$. To this end, a recent corruption scandal ${ }^{3}$ has

\footnotetext{
${ }^{1}$ As Andrew Baldwin (2012) discusses, the term futurity refers to the ways in which "the future is rendered knowable through specific practices (i.e. calculation, imagination, and performance) and, in turn, intervenes upon the present through three anticipatory logics (i.e. pre-caution, preemption and preparedness)" (p. 173).

${ }^{2}$ This discussion is expanded on pages 12-14.

${ }^{3}$ This ongoing scandal first became public in February 2019 when The Globe and Mail exposed allegations of political interference and possible obstruction of justice by the Prime Minister's Office (PMO). Former Liberal Member of Parliament and Attorney General of Canada, Jody Wilson-Raybould asserts that the PMO pressured her to intervene in an ongoing criminal court proceeding involving the prominent Canadian construction company, SNC-Lavalin, which has been involved in a plethora of significant legal issues, both past and present. Since the scandal became public, there have been many high-profile resignations in the Liberal government and ultimately has resulted in the expulsion of Wilson-Raybould not only from the Liberal cabinet, but more recently, the Liberal caucus. (See more at https://en.wikipedia.org/wiki/SNCLavalin_affair)
} 
revealed the deeply unethical nature of the Canadian political system in a new and profound way. It is poetic justice that it was the Honourable Jody Wilson-Raybould, a Kwakwaka'wakw woman, who publicly highlighted the entrenched systems of corruption inherent to the founding of this nation in her statement to the Justice Committee on February 27, 2019:

The history of Crown-Indigenous relations in this country includes a history of the rule of law not being respected. Indeed one of the main reasons for the urgent need for justice and reconciliation today is that in the history of our country we have not always upheld foundational values such as the rule of law in relations to Indigenous peoples. And I have seen the negative impacts for freedom, equality and a just society this can have firsthand. (“Jody Wilson-Raybould's Opening Statement," 2019)

Alluding to the structures of settler colonialism in Canada, Wilson-Raybould underlines the problematic-- and deeply unethical-- relationship between the federal government and Indigenous peoples. What is more, her testimony draws attention to the truly fragile nature of the Canadian state. She powerfully concludes by citing her responsibilities as a Kwakwaka'wakw woman: "I come from a long line of matriarchs and I am a truth teller in accordance with the laws and traditions of our Big House. This is who I am and this is who I always will be" ("Jody Wilson-Raybould's Opening Statement," 2019). Invoking her traditional epistemologies in this context is a powerful illustration of how these truth-telling and deeply reciprocal systems are so ideologically incompatible and irreconcilable with the inherently coercive nature of Canadian settler governmentality.

My thesis operates within this current context wherein the legitimacy of the Canadian state is increasingly being tested and questioned. As a case study, this project broadly explores the use of reconciliation discourse in political strategy and seeks to draw connections between policy and practice. My analysis is a multi-method endeavour, which first reviews current federal land claims and self-government frameworks and situates these processes within their relevant historical contexts. Through techniques of Critical Discourse Analysis (CDA), I then analyze 
government-issued public news releases from the now-defunct federal Department of Indigenous and Northern Affairs Canada (INAC) to illustrate the translation of these processes into public, press release discourse. The full list of news releases constituting my sample for analysis is found in Appendix II. As a site of political communication, these documents are deliberately public-facing and generally function as the public's window into governmental decision-making. In this project, I seek to answer: how is reconciliation discourse operationalized as a tool of assimilation that works to reproduce logics of settler colonialism and maintain occupation of the lands now known as Canada? I focus on federal policies related to land claims settlements and self-government agreements because, as key federal policy areas related to Indigenous peoples, they are both deeply connected to not only the state's vision for reconciliation, but also to the continued settler occupation of land. This is a logical site of focus also because my understanding of settler colonialism is intricately related to land (Coulthard, 2014; Manuel, 2017; Simpson, 2011). Consequently, this project centres decolonization-- that is, the repatriation of stolen Indigenous land-- as an overarching and guiding imperative (Tuck \& Yang, 2012). To this end, this analysis seeks to disentangle how capitalist, colonial frameworks like land claims settlements and self-government agreements operationalize reconciliation discourse to maintain a permanent hold on Indigenous lands.

Before expanding upon a few key findings, I will first outline the structure of this project. To begin, I carefully and thoroughly situate my topic within the necessary sociohistorical and political contexts. Here, I unpack key concepts that are foundational to my project such as settler colonialism (Wolfe, 2006) and decolonization (Tuck \& Yang, 2012), as well as provide a critical background to the Department of INAC. After this starting section, I outline my methodological framings of this project. I draw on Elizabeth Carlson's insightful work on ethical anti-colonial 
research, as well as the works of Andrea Doucet, Natasha S. Mauthner (2005), and Rita Dhamoon (2009) to complement this rich discussion with feminist and post-structural perspectives that highlight the relationship between discourse and the production and maintenance of hegemonic power structures like capitalism, patriarchy, heteronormativity, ableism, and white supremacy. Maile Arvin, Eve Tuck, and Angie Morrill (2013) further articulate the need to understand settler colonialism as a gendered process (p. 9), and thus I will briefly turn to their work to discuss the crucial links between heteropatriarchy and settler colonialism. With these frameworks in mind, I then draw on Paul Lasarsfeld's (1941) theorization of critical policy research to situate my method for policy review in the context of political communications. Moreover, I look to Frank Fischer (2009) and Norman Fairclough (1995) to further elucidate my approach to CDA. In particular, Fischer's work addresses the function of political discourse while Fairclough's method of CDA understands linguistic analysis as a means of shaping and enacting social structures and practices. These perspectives are key to my method because I am studying INAC news releases simultaneously as political documents broadly, and also as a particular manifestation of settler colonial logics through the use of reconciliation discourse.

In the next section, I delineate my four main theoretical underpinnings. In particular, I turn to Yellowknives Dene scholar Glen Coulthard's (2014) recognition paradigm and Tsalgi scholar Jeff Corntassel and Kahnawake Mohawk scholar Taiaiake Alfred's (2005) discussion on the politics of distraction. Because the concept of reconciliation is not inherently tied to the repatriation of occupied Indigenous land, these scholars have criticized the neoliberal use of discourses of reconciliation as a means of distracting Indigenous communities from movements of decolonization and resurgence. Further, I highlight Michel Foucault's work on 
governmentality as an underlying framework to help elucidate the federal government's problematic dealings with Indigenous peoples as operating within entrenched and intertwined systems of colonialism and capitalism, for example. In contrast to these theories, moreover, I draw on the insights of Anishinaabe kwe Leanne Betasamosake Simpson (2011) to reflect on the importance of community-centred, Indigenous resurgence. Simpson's theorizing is influential and speaks to the critical need for community-based, not state-based, methods for decolonization.

In a penultimate section, I review current critical analyses of reconciliation politics in Settler Colonial Studies and Canadian Studies in light of my discourse analysis; I identify an important neglect, if not omission, of meaningful interrogations of the Canadian federal department responsible for its fiduciary duties to Indigenous peoples, formerly known as INAC. As a crucial and integral node of the all-encompassing assemblage of institutionalized settler colonial machinery in Canada, critical research of INAC is relatively sparse, an important aspect of context at a crucial moment when reconciliation discourse continues to pervade the Canadian public sphere. My research addresses this omission and adds an original, thoughtful contribution as it critically engages with discourses of reconciliation in INAC public news releases and argues that reconciliation functions rhetorically as an allusive, shape-shifting concept to serve an inherently assimilationist state agenda. These insights will pave the way for a thorough and engaging discussion in a concluding section that showcases the findings of my empirical research. My discursive analysis will serve to delineate how "the overriding objective in all of the government's dealing with Indigenous peoples is to have continued unfettered access and control over Indigenous lands” (Manuel, 2017, p. 204). Through my analysis, I argue that reconciliation is no exception to this rule. 
My analysis consequently begins with a brief review of the federal policies at the centre of my project: the two separate land claims processes (Comprehensive and Specific), and selfgovernment agreements. With this sociohistorical context in mind, I then organize my findings into three thematic sections: I examine the role of certainty in extinguishing Indigenous peoples' inherent rights; the fundamentally asymmetrical power dynamic at the negotiating table; and the frameworks' role in historicizing colonialism by situating injustices in the past. Emerging primarily from critical scholarship in the field, these organizing themes clearly delineate the intersection between policy and practice; my analysis weaves critical scholarship of land claims and self-government processes with illustrations of these critiques in practice through INAC news releases. In conversation with Coulthard's politics of recognition, I work to show the limitations of "a recognition-based approach to reconciling Indigenous peoples' assertion of nationhood with settler state sovereignty via the accommodation of Indigenous identity-related claims" (p. 151). Broadly, my findings show that the concept of reconciliation is used in a plethora of different rhetorical and discursive ways in the corpus, and thus serves just as many different political functions in the interests of upholding settler colonialism in Canada.

After a careful review of the federal policies and a critical analysis of 39 INAC news releases related to land claims settlements and self-government agreements ${ }^{4}$, I argue that the government uses ambiguity (Fischer, 2009) as a deliberate rhetorical manoeuvre to create a conceptual void wherein reconciliation holds so many meanings that it is rendered effectively meaningless. Overall, I argue that reconciliation discourse has a unique, shape-shifting quality in political communications and functions in these documents to reproduce settler colonialism at

\footnotetext{
${ }^{4}$ Items 1 to 39 in Appendix II, listed reverse-chronologically in two groups, Land Claims Settlements and Self-Government Agreements.
} 
distinct and copresent levels of discourse (Fairclough, 1995). For example, one instance delineates that "this settlement brings closure to these longstanding claims once and for all. Claim settlements right past wrongs and honour legal obligations owed to First Nations" (Item 20). Situated within discourse inspired by the Truth and Reconciliation Commission of Canada $(\mathrm{TRC})^{5}$, this excerpt explicitly draws on the aforementioned themes of certainty and history to construct a false distinction between Canada's colonial past and an oft-taken-for-granted postcolonial, reconciled present. Item 20 shows how, as a process of power, the theme of finality in the context of reconciliation discourse effectively conceals the federal land claims frameworks' duplicitous agenda; the positive framing of resolving these claims 'once and for all' does indeed transparently highlight the problematic termination of Aboriginal rights and title ${ }^{6}$. By extinguishing Aboriginal title with finality, land claims settlements essentially grant federal jurisdiction over the past, the unknown, and the future (Samson, 2016, p. 93). Yet, this is effectively obscured by the reconciliatory rhetoric of 'righting past wrongs.' It may seem counterintuitive, but because the government is able to construct this definitive end-point to Indigenous nations' claims to land, the future of the settler state is in fact solidified. Canada has constructed its relationship with colonization as a uniquely historical one; while there is no specific event or moment marking colonization's end, its finality is widely assumed and accepted as fact. Australian scholars Elizabeth Strakosch and Alissa Macoun (2012) call this the vanishing end-point of settler colonialism, which explains the moment of colonial completion as "when the

\footnotetext{
${ }^{5}$ Mandated in 2008 by the Indian Residential Schools Settlement Agreement, the Truth and Reconciliation Commission of Canada worked to document the history and impacts of the Indian Residential School System. Its widely-cited 94 Calls to Action and its lengthy Final Report were both published in 2015. I discuss the TRC at length in my Literature Review (pp. 51-57; 60-62). ${ }^{6}$ This is a central criticism of both land claims and self-government processes, and will be discussed at length in Theme 1 of my Analysis chapter (pp. 75-80).
} 
settler society will have fully replaced Indigenous societies on their land, and naturalized this replacement" (p. 42). I argue that these overtly assimilatory objectives are effectively hidden behind the discursive ambiguity that INAC news releases construct through reconciliation.

In contrast, Dhillon (2017) importantly points out, "decolonization, as both a discursive and practical undertaking, exists entirely outside the purview of a colonial social order" (p. 17). Many other prominent scholars like Simpson (2011; 2017), Coulthard (2014), and Unangax feminist Eve Tuck and scholar K. Wayne Yang (2012), echo this notion; thus, the limitations of state-led projects like reconciliation are important and must not be overlooked. As such, my findings highlight that because the narrative of land claims settlements and self-government agreements are contained within the Canadian colonial purview and often operationalize reconciliation discourse, they categorically cannot function as tools for decolonization. This project is thus a critical inquiry into how these themes operate simultaneously in INAC policy and news releases related to land claims settlements and self-government agreements to a larger pattern of discourse and political strategy surrounding the state-crafted vision for reconciliation. My findings work to show how the concept of reconciliation, while operating largely at a latent, discursive level, works in political communication to effectively undermine Indigenous efforts towards resurgence and decolonization in order to maintain settler colonial hegemony in Canada. 


\section{Statement of Positionality}

Before continuing, I would like to briefly situate myself in this work. Originally from Winnipeg, Manitoba, I am a fourth-generation Canadian whose family originates from Western Europe. My family has thus benefitted from the ongoing dispossession and displacement of the Cree, Anishinaabe, Dene, Dakota, Oji-Cree, and Métis peoples as we continue to call their traditional territory in Treaty 1 land, our home. My experience comes from a context of considerable privilege as a white/cis/hetero woman. As I live and study in the heart of the Dish with One Spoon territory, a treaty land historically shared by the Anishinaabe, Mississaugas, and Haudenosaunee peoples, I acknowledge my complicity in the ongoing occupation of these lands. I approach this research as an outsider and as someone working towards allyship. As a settler, I am interested in interrogating the inner workings of INAC as a crucial and integral node of the otherwise all-encompassing assemblage of institutionalized settler colonial machinery in Canada. To this end, I problematize reconciliation as a key facet of colonial governmentality as I hope to conceptually disrupt the otherwise accepted Canadian sovereignty that continues to violently displace and dispossess Indigenous peoples from their homelands. I recognize the limitations of my work, and understand my solidarity as "an uneasy, reserved, and unsettled matter that neither reconciles present grievances nor forecloses future conflict" (Tuck \& Yang, 2012, p. 3). I do this research because I want to live-- or learn how to live-- on these lands in a good way. For me, this looks like not only challenging taken for granted terms like reconciliation and exposing ways that this discourse is duplicitous, but also interrogating the institutions of settler colonialism that allow occupation to continue largely unchallenged by mainstream Canada in order to create a fuller picture of what it means to be Canadian. 


\section{Chapter 1: Contextualizing This Project}

Before diving into the main methodological and theoretical aspects that guide my research project, I will first unpack a number of terms that are fundamental to my approach. Whereas my next section provides the methodological foundation upon which I build the necessary structure to answer my research question, this first chapter serves to situate reconciliation discourse more generally within the socio-cultural and political context of Canada as a settler nation. First, I work to outline the particular context of settler colonialism in Canada; the concept of settler colonialism warrants a dedicated discussion as it is an essential term to this project. Second, I explore the notion of decolonization as a guiding imperative that underpins the broader implications of my research. This is a crucial discussion because decolonization is the overarching framework that guides my entire project; as will be expanded upon in this current section, the repatriation of stolen Indigenous land is unequivocally and incommensurably central to this project. I also expand on the particulars of the Federal department charged with fulfilling the Crown's fiduciary responsibility to Indigenous peoples, formerly known as INAC. My project centres INAC as a specific instantiation of settler colonial logic in Canada and thus, a brief discussion of the department's history is necessary. In addition to discussing INAC as a federal entity, I will unpack the fraught and often misunderstood fiduciary relationship between the Crown and Indigenous peoples that was legally established in Guerin v. The Queen (1984). As a first chapter, this section plays an important role in setting the stage for my both my policy review and CDA. This context is needed first in order to then meaningfully interrogate how, as tools of assimilation, land claims and self-government processes function within reconciliation politics to uphold the unquestioned colonial occupation of Indigenous lands.

\section{Settler Colonialism as a Central and Pervasive Logic in Canada}


As an underlying framework that permeates every aspect of life in the nation of Canada, settler colonialism's logics are centred on land theft, genocide, and assimilation. Here, I contextualize settler colonialism in three critical ways: its relationship with upholding structural land dispossession, logics of elimination, and hegemony, more broadly. To start, in his oftquoted work, "Settler Colonialism and the Elimination of the Native," Patrick Wolfe (2006) importantly understands settler colonialism as a process, not an event (p. 388). Differing from extractive colonialism, settler colonialism depends not only on the dispossession and displacement of Indigenous peoples from their lands, but also consequently on eradicating Indigenous ways of life in order to absorb Indigenous peoples into the colonial society. This is not to say that settler colonialism is not fundamentally entangled within capitalist resource extraction, which of course it is, but rather that settler colonialism does not simply involve extraction, but as Wolfe (2006) aptly theorizes, "settler colonialism destroys to replace" (p. 388). To this end, when colonizers arrived on Turtle Island ${ }^{7}$, they brought with them their hierarchical value systems of social organization, political governance, and economic structure; settler colonialism intersects with violent and pervasive systems of power such as-- but not limited to-capitalism, white supremacy, heteropatriarchy, classism, and ableism. Simpson (2017) further articulates that she experiences settler colonialism "as a gendered structure and a series of complex and overlapping processes that work together as a cohort to maintain the structure" (p. 45). Central to this logic, moreover, is the theft and subsequent commodification of land. As such, Wolfe (2006) maintains that “territoriality is settler colonialism's specific, irreducible element” (p. 388). I would add, moreover, that territoriality is central to settler colonialism

\footnotetext{
${ }^{7}$ For some Indigenous communities, Turtle Island refers to the land that we now know as North America, inclusive of Canada, The United States of America, and Mexico.
} 
because it is fundamentally tied to the capitalist economic structure, which depends on extractivism, an ethos privileging resource extraction, thus rendering access to land absolutely essential to the colonial state.

Like other Commonwealth settler colonies like Australia and the South Island of Aotearoa/New Zealand, at its core, the Canadian state was founded on the international legal principle terra nullius, or "nobody's land." More commonly known as the problematic and white supremacist Doctrine of Discovery, this principle legitimized the Europeans' "[claim] rights of sovereignty and ownership of regions they claimed to discover" (Mahoney, 2017), justifying the unilateral and sovereign claim to dispossess Indigenous peoples from their lands. As I alluded to earlier, the land was not vacant and the legality of the Canadian State should thus be called into question. And while the Royal Proclamation of 1763 did indeed recognize Indigenous peoples' inherent and pre-existing right and title to land, by the time the Constitution Act was passed in 1867, the Crown no longer saw value in its strategic alliance with Indigenous nations and moved to "assert unilateral sovereignty over the people and lands" (Dhillon, 2017, p. 54-55). The 1867 Constitution Act institutionalized the wardship of Indigenous peoples to the Canadian state, further solidified by the introduction of the Indian Act ${ }^{8}$ in 1876, which paved the way for the creation of the Department of Indian Affairs in 1880. This discussion will be picked up later in the current chapter. For now, borrowing from Dhillon (2017), "one thing is indisputably clear: the intergenerational and multifaceted impact of the colonial 'founding' of Canada is ever

\footnotetext{
${ }^{8}$ The Indian Act is the primary document through which the federal government controls and regulates Indian status, governments, reserve land management. Many thorough and thoughtful critiques of this paternalistic statute exist. See, for example, Lawrence, B. (2004). "Real" Indians and Others: Mixed-blood Urban Native Peoples and Indigenous Nationhood. Vancouver: UBC Press and Kelm, M-E., \& Smith, K. D. (2018). Talking back to the Indian Act. Toronto: University of Toronto Press.
} 
present. The effects are material and discursive. They are social and political” (p. 8). Moreover, colonial violence is not temporally contained in the arrival of settlers, but rather, "is reasserted each day of occupation" (Tuck \& Yang, 2012, p. 5) and indeed unequivocally continues today.

While terra nullius is the underlying principle to settler colonialism, logics of elimination engage with this principle to uphold, legitimize, and naturalize structural dispossession ${ }^{9}$ and violence against Indigenous peoples and their lands. As Wolfe (2006) explains, the logic of elimination not only encompasses the deliberate and systematic genocide of Indigenous peoples, but is also an organizing principle, which works to found a new, colonial society on stolen land (p. 388). Strakosch and Macoun (2012) further expand on Wolfe's logic of elimination, articulating that it also includes assimilative projects that aim to sever Indigenous connections to their land and communities (p. 44). The continued existence of Indigenous peoples, then, poses a direct threat to settler governance because "in Western polities, land is simultaneously a physical commercial resource and a marker of the boundaries of sovereign authority" (Strakosch \& Macoun, 2012, p. 45). This process works to not only consolidate power and strictly police access to land, but it also works to reorganize communities, identities, and ultimately, political subjectivity (Dhillon, 2017, p. 17). Land claims settlements and self-government agreements are examples of tools of assimilation and control in this way. Further to this end, Strakosch (2016) exposes the fragility of settler colonial states, as she argues that "the flip side of colonization being a structure rather than an event is that settler sovereignty is a performance claiming to be an essence" (p. 20). As a structure, then, settler colonialism simultaneously privileges the essence of settler sovereignty and targets Indigenous self-determining political authority in its

\footnotetext{
${ }^{9}$ Structural dispossession refers to the many different systems and processes in place that work to maintain settler occupation. As we will see, land claims settlements and self-government agreements are very much a part of this complex structure.
} 
logic of elimination to maintain its unquestioned claim to Indigenous land. My critical discussion of land claims settlements and self-government agreements (pp. 68-75; 80-86) later makes these links very clear and highlight these logics in a practical way.

Furthermore, the Canadian state and its actors work tirelessly, both consciously and subconsciously, to normalize settler colonial logics through what Mark Rifkin (2013) calls settler common sense. Antonio Gramsci explains that hegemonic social orders are maintained and reproduced as some institutions violently uphold social boundaries and rules, like the military or police, while other institutions, like education and the media, passively induce consent to this order through establishing hegemony (Durham \& Kellner, 2006, p. XV). Thus, hegemony is established primarily through state domination while the institutions of civil society play the important role of actually upholding these norms. Settler common sense thus exists within in this context of hegemony; to this end, Coulthard (2014) argues that "settler colonialism should not be seen as deriving its reproduction solely from its strictly repressive or violent features, but rather from its ability to produce forms of life that makes settler colonialism's constitutive hierarchies seem natural" (p. 152). For Rifkin (2013), the affective experience of settler colonialism as a system of coercive incorporation and expropriation is understood as settler common sense: "the legal and political structures that enable [settlers] access to Indigenous territories come to be lived as given, as simply the unmarked, generic conditions of possibility for occupancy, association, history, and personhood" (p. 322-23). Settler common sense is exactly that: a set of self-evident, status quo, and invisible attitudes and behaviours that shape everyday life in settler states like Canada. Accordingly, these hegemonic structures of land/property ownership and democratic governance, in concert with historical and ongoing dispossession and displacement of Indigenous bodies from the land are, Raymond Williams' terms, "renewed, recreated, defended, 
and modified" in a multitude of mundane ways (as cited in Rifkin, 2013, p. 327). This highlights the shifting form of settler colonial governmentality, a concept which I will discuss at length on pages 45-47. As Goenpul scholar Aileen Moreton-Robinson (2009) articulates, "colonization has not ceased to exist; it has only changed in form from that which our ancestors encountered" (p. 11); and so, while the form of colonization changes over time, the logics remain the same in the project of structural dispossession. To this end, I argue that, facilitated by reconciliation discourse in political communications, land claims settlements and self-government agreements are indeed examples of how the Canadian state has been able to change the form of the settlement process in Canada into a less overtly assimilatory project while maintaining the overall function that validates both the federal government's claim to sovereignty, and its exclusive control over land.

\section{Decolonization as Imperative to This Work}

The above socio-cultural and political discussion of settler colonialism serves to highlight that the ultimate aim of the settler state is to secure "a permanent hold on specific, conquered locales [and therefore] structural decolonization, as both a discursive and practical undertaking, exists entirely outside the purview of a colonial social order" (Dhillon, 2017, p. 17). This imperative is widely echoed by many Indigenous scholars (Simpson, 2017; Coulthard, 2014; Manuel, 2017). Coulthard (2014), for one, articulates that authentic decolonization must directly account for "the multifarious ways in which capitalism, patriarchy, white supremacy, and the totalizing character of state power interact with one another" (p. 14). Moreover, Tuck and Yang (2012) importantly emphasize that decolonization must unequivocally work towards not only the repatriation of Indigenous lands (p. 7), but also involve a complete change in the order of the world (Fanon, 1963, as cited in Tuck \& Yang, 2012, p. 31). As a truly unsettling concept, they 
articulate that critical consciousness is not adequate in confronting settler colonialism: as a project that "is accountable to Indigenous sovereignty and futurity" (Tuck \& Yang, 2012, p. 35), decolonization can and will only occur when stolen lands are rightfully returned (Tuck \& Yang, 2012, p. 19). Situated within this decolonial paradigm, my research project explicitly centres the repatriation of Indigenous land as an overarching and guiding principle that informs how this work is carried out ${ }^{10}$. For this reason, I focus on land claims settlements and self-government agreements as particular frameworks of settler governmentality that perpetuate the Canadian state's unilateral control over the ways in which Indigenous peoples interact with land and community.

To this end, Tuck and Yang (2012) argue that in contrast to decolonization, the concept of reconciliation seeks to rescue settler normalcy and settler futurity (p. 35). My research project seeks to confront these logics. Considering settler colonialism as a violent structure and the Department of INAC as a particular instantiation of this colonial violence, Manuel (2017) succinctly articulates that "you cannot simply reform your racist state by enacting a few more programs and delivering a few more services. It is imbedded in the very nature of Canada and requires a completely new deal" (p. 66). Although the structure of INAC has changed significantly since its inception in 1756 , the fundamental settler colonial logics of white supremacy, heteropatriarchy, classism, and capitalism continue to work intrinsically to maintain the status quo, naturalized violence of Canadian colonial hegemony. Moreover, Simpson (2017) echoes this, and illustrates that in the specific context of reconciliation politics, "neoliberal states manipulate the processes that maintain settler colonialism to give the appearance that the structure is changing" (p. 46). Important to my empirical research, Coulthard (2014) also

${ }^{10}$ This will be picked up in Chapter 2 (pp. 22-28). 
emphasizes that these processes of reconciliation remain "structurally committed to maintaining -- through force, fraud, and more recently, so-called negotiations-- ongoing state access to the land and resources" (p. 7). These 'so-called negotiations' are at the centre of my empirical research as I critically engage with both the land claims and self-government processes themselves and discourses of reconciliation present in INAC public news releases related to these frameworks. 


\section{INAC as an Instantiation of Settler Colonial Governmentality in Canada}

The institutionalized wardship of Indigenous peoples to the colonial state began in the early days of colonization and has mutated many times since then. Established during the Seven Years War (1756-63), the British government created the first Indian Department (Derworiz, 2018) primarily as a means of preventing French-Indigenous alliances. This department remained under British control until confederation in 1867, when the responsibility of "Indians and lands reserved for Indians" were transferred to the newly-formed Canadian government via Section 91(24) of the British North America Act (Derworiz, 2018). The Department of Indian Affairs was then established in 1880. This "miniature government" entrenched the administrative and bureaucratic relationship between the state and Indigenous peoples; it consisted of an inside service, which consisted of the bureaucrats at the headquarters in Ottawa, and an outside service, which comprised Indian agents (Derworiz, 2018). Notably, Indian Affairs was transferred to the Department of Mines and Resources in 1936 (Derworiz, 2018), which represented a clear shift toward intense land and resource exploitation (Pasternak, 2017, p. xiii). The department remained there until 1950, when it was made a branch of the Department of Citizenship and Immigration until 1965 (Derworiz, 2018). This can also be read as a move to create a clear and deliberate distinction between Indian status and land rights. Since 1966, the department has been renamed to reflect the vernacular of the day; most recently, it was known as Aboriginal Affairs and Northern Development Canada from 2011-2015, and Indigenous and Northern Affairs Canada from 2015-2017.

Positioned in the spirit of 'reconciliation,' however, INAC dissolved into two new departments in late 2017. Dividing up responsibilities, Crown-Indigenous Relations and Northern Affairs Canada (CIRNAC) and Indigenous Services Canada (ISC) were restructured 
according to recommendations made 20 years prior in the 1996 Royal Commission on Aboriginal People (RCAP) final report. Anishinaabe scholar Veldon Coburn (2017) critically interrogates the motivations behind this seemingly positive shift in government organization, and argues that the RCAP recommendation to split INAC is no longer relevant in today's political landscape ${ }^{11}$. Echoing the discussion above, as a key facet of settler colonial governmentality, it is clear that while INAC's structure has changed significantly, the logics of theft, dispossession, displacement, and elimination upon which it is predicated have not. The key policy areas for CIRNAC and ISC still promote assimilationist agendas through, among many other tools, land claims settlements and self-government agreements, for example. To this end, Simpson (2017) contends that if settler colonialism is a structure made up of processes, the structure is still able to shift and adapt. I argue that INAC's organizational shifts represent an example of how re this adaptation produces policies that are not only predicated on ensuring ongoing federal access to and control of land, but importantly also situated in reconciliation politics.

It is also important to briefly discuss the effects of the department's different acronymic iterations. Unlike the early Department of Indian Affairs or the more recent Aboriginal Affairs and Northern Development Canada, which referenced the Crown's legally-binding fiduciary obligation, the current nomenclature (CIRNAC and ISC) as well as the previous (INAC) do not. For one, established in Guerin v. The Queen (1984), the fiduciary relationship between the Crown and status Indians ${ }^{12}$ means that the Crown is legally required exercise its power with 'loyalty,' in effect regulating "the manner in which the Crown exercises its discretion in dealing with the land on the Indians' behalf" (p. 385). The duty arises because "the Indian interest in the

\footnotetext{
${ }^{11}$ See Coburn, V. (2017) for further explanation.

${ }^{12}$ A status Indian is a person who is registered under the Indian Act.
} 
land is inalienable except upon surrender to the Crown" (Guerin v. The Queen, 1984, p. 376). This decision made clear that the government has a set of legal obligations to status Indians. Moreover, the inclusion of Section 35 of the Constitution in 1982 formalized the rights of 'Aboriginal people,' which includes status Indians, Inuit, and Metis peoples. Thus, when the federal department reflected the terms 'Indian' and 'Aboriginal,' this referenced legal categories that, for the Crown, contain a set of responsibilities and obligations. Changing the name to 'Indigenous' is thus problematic because 'Indigenous' is not a group that the Crown has legal control over and fiduciary obligations toward, and this change obscures the fact that these fiduciary obligations are only owed to status Indians, and not 'Indigenous peoples.' As the 1939 SCC Reference Re Eskimos and the 2016 Daniels v. Canada decisions affirmed that respectively, the Inuit and Metis should be considered Indians under the Indian Act, the Crown thus does indeed have a constitutional responsibility to status Indians, as well as Inuit and Metis peoples. Notably, however, the term 'Indigenous' is not legally enshrined. INAC, which indeed sounds much like Indian Affairs, implicates a blanket fiduciary relationship for all Indigenous peoples despite the fact that the relationships between the Crown and status Indians/Inuit/Metis are still very different. To contextualize the federal department, I simply intended to make the distinction here between the legal relationships established by Guerin, and subsequently implicated by Reference Re Eskimos and Daniels, in order to draw attention to the way that, through the years, renaming INAC has resulted in the co-optation of the term 'fiduciary' into a more passive 'responsibility' to Indigenous peoples broadly rather than a legally-binding obligation owed only to status Indians. 


\section{Chapter 2: Methodology and Methods}

At its core, this project is a multi-method endeavour that examines the ways in which reconciliation discourse functions discursively in federal political communications to uphold the unquestioned settler colonial occupation of the lands now known as Canada. To accomplish this, I first conduct a policy review of federal land claims and self-government frameworks. This review consists primarily of a historical and contextual overview of the respective INAC policies. This policy review takes place within the broad framework of political communication, which is typically defined in terms of political campaigns rather than governmental communication (Stuckey, 2018). Political communication is generally studied through organizational norms and intra-office communication rather than public communications, which is instead generally studied in terms of propaganda and spin. In this context, INAC news releases are, by definition, more characteristic of formal governmental communication than strategic political communication. Yet, they are public-facing documents meant for the consumption of news media and the wider Canadian public. I challenge the taken-for-granted, informational nature of these documents and argue that they too serve a political purpose in furthering the government's political strategy. In particular, I argue this is done by using reconciliation discourse ambiguously in communications. Distinct from the alternatives above, my study instead seeks to make connections between policy and practice and discuss the ways that hegemonic ideologies are translated from state-led processes into public discourse through the particular political communication venue of news releases.

With this in mind, I engage with critical scholarship on the respective land claims and self-government policies to discuss the limitations of these state-led processes of reconciliation. I 
operationalize a CDA of public news releases issued by INAC from $2008-2017^{13}$ to illustrate the application of these critiques in practice. As I will discuss, this project is situated well within sociologist Paul Lazarsfeld's theorization of critical communications research. For my main empirical work, I look to Carol Grbich (2013), who succinctly describes discourse analysis as a means of exploring "how a discourse developed (historical formation [...]); how it works (ordering and exclusion); and what the outcomes have been" (p. 246). To this end, my project works within a critical theoretical research paradigm; anti-colonial and feminist epistemologies largely inform my methodological choices and guide my method. Sandra Harding makes the important distinction, noting that while methodology guides how the research does or should proceed, the method is the technique for gathering the empirical data (as cited in Doucet \& Mauthner, 2005, p. 38). As such, critical and poststructural positions are fundamental to both my methodology and method as I aim to challenge dominant narratives in INAC documents and unpack how these narratives serve to further entrench settler colonial governmentality. The following section will thus delineate my main methodological choices and expand on my method. First, I will discuss how anti-colonial and feminist epistemologies have informed my project. I will then unpack my particular approach to policy review before outlining my method for CDA.

\section{Anti-Colonial Methodologies}

I turn primarily to Carlson's powerful piece, “Anti-Colonial Methodologies and Practices for Settler Colonial Studies" (2017) to outline "methodological options for conducting appropriate and decolonizing research that do not rely on attempting to implement Indigenous

\footnotetext{
${ }^{13}$ An expanded discussion on the significance of these particular documents and the chosen date range can be found in Appendix I on pages 101-105.
} 
research methodologies" (p. 498). An invaluable framework for my own project, her work clearly delineates the ethical issues related to implementing Indigenous methodologies as a settler: because as a settler I do not possess Indigenous understandings of worldview or experience, I should not attempt to conduct research with Indigenous methodologies, but rather with anti-colonial frameworks. This is an extremely influential insight because the distinction between Indigenous and anti-colonial methodologies is critical and is indeed reflected in my project. Importantly, she maintains that "with their focus on power dynamics, hegemony and hierarchies, and their emphasis on relationships between the personal and political" (Carlson, 2017, p. 499) critical race and feminist lenses, for example, are useful in articulating an anticolonial research methodology. It would be inappropriate for me to employ Indigenous methodologies in my empirical work not only because I am a settler and am not meaningfully engaged in Indigenous epistemologies, but also because my project focuses on the heart of settler colonial institutional violence that is, the Canadian government itself, and more specifically, INAC. I have thus appropriately situated my project within critical, feminist, anti-colonial paradigms.

Employing anti-colonial methodologies, moreover, requires centring Indigenous resurgence and necessarily the repatriation of Indigenous land; crucially, Carlson (2017) continues, "anti-colonialism involves the recovery of traditional knowledge as a strategy that resists the replacement of Indigenous ways and knowledges with Western ways and knowledges, processes endemic in colonialism" (p. 500). While I am not operationalizing Indigenous methodologies, my project is still premised on the notion of decolonization as unequivocally and necessarily the recovery of space that is currently occupied by settler colonialism. In questioning whether it is ever appropriate, or even possible, for white settler scholars to "interpret colonized 
peoples' experiences on their own terms, and to develop understandings not explicitly or implicitly distorted by settler colonial privilege, Eurocentrism, or white supremacy" (p. 500), Carlson (2017) proposes these challenges should engender humility rather than paralysis. She continues, "with Indigenous resurgence at the centre of anti-colonialism, the roles of white settler academics are at the periphery, making space, and pushing back against colonial institutions, structures, practices, mentalities, and land theft" (Carlson, 2017, p. 500).

Moreover, Carlson proposes eight principles to guide anti-colonial methodology; three of these principles directly relate to my project as I am an outsider to the community. First, 'resistance to and subversion of settler colonialism' is a fundamental purpose of my work as I look at one specific colonizing practice and seek to disrupt this by employing anti-colonial practices to ultimately "push back against colonial institutions to make space for Indigenous resurgence" (Carlson, 2017, p. 503). Second, Carlson (2017) advises settler scholars to honour 'relational and epistemic accountability to Indigenous peoples,' which I plan to do by centring Indigenous scholarship and literatures in my theoretical perspectives and literature review. Third, picking up on the work done by Anishinaabe kwe Kathy Absolon and Cree scholar Cam Willett in their chapter "Putting Ourselves Forward: Location in Aboriginal Research" (2005), Carlson (2017) emphasizes the need for anti-colonial settler scholars to explicitly state and interrogate "their own social location with regards to the research and with regards to settler colonialism" through a critical reflexivity of how we contribute to perpetuating colonialism (p. 502). This reflexivity can be seen in my statement of positionality, for example, and is an imperative I stick to throughout my project. Linked to locating oneself in their research is "resisting neutrality, objectivity, and invisibility" (Carlson, 2017, p. 510). To this end, I have made the conscious 
choice to employ first-person pronouns. In keeping with anti-colonial principles, my project rejects an impersonal, objective-seeming, and authoritative voice.

Expanding further on this concept of reflexivity, I will briefly draw from Absolon and Willett's aforementioned chapter directly. As they remind readers, locating oneself in their work is not only critical in addressing the power structures that the researcher themself participates in and benefits from, but this reflexivity also introduces a dynamic of accountability whereby the researcher ensures they are connected with and accountable to the community for the knowledge their work creates (Absolon \& Willett, 2005, p. 97). To this end, Absolon and Willett (2005) articulate how "location exposes the researchers' current context as details about [...] where they are from, their race and gender, who they are connected to, and what their research intentions are become revealed" (p. 118). Furthermore, the scholars maintain that any work that centres Indigenous peoples requires "a complete deconstruction of the history and application of colonial and racist ideology and, most importantly, of the impact (personal and political) of racism (Absolon \& Willett, 2005, p. 111). I attempt to address this notion by thoroughly contextualizing my project within the history of settler colonialism as I seek to expose the ways in which it continues to operate today. I took care to leave ample room to make sure the proper contextualization was able to take place, so that the reader could have the fullest possible picture of what settler colonialism looks like in Canada, both past and present.

I would be remiss if I did not unpack the ways in which Maori scholar Linda Tuhiwai Smith's seminal collection, Decolonizing Methodologies: Research and Indigenous peoples (2012), has also informed my project. In keeping with Carlson's (2017) advice, I do not seek to appropriate Smith's methodologies in research per se, but rather use her insights to further contextualize my work. For instance, Smith (2012) outlines twenty-five of what she calls 
'Indigenous projects.' Briefly, the project of reframing works to take "much greater control over the ways in which issues affecting Indigenous peoples and social problems are discussed and handled" (Smith, 2012, p. 255). In my work, reframing works to not only expose problematic historical narratives that are often taken for granted, but also confront these narratives with extensive contextualization. Speaking to one last point, moreover, Smith (2012) importantly reminds readers that "taking apart the story, revealing underlying texts, and giving voice to things that are often known intuitively does not help people improve their current conditions. It provides words, perhaps, an insight that explains certain experiences-- but it does not prevent someone from dying" (p. 36). This assertion is a powerful and necessary reminder of the limits of my work in as a critical policy researcher.

\section{Feminist Methodologies}

Building on the above anti-colonial insights, I turn to Doucet and Mauthner who review key academic contributions and trends in feminist methodologies and epistemologies in their chapter in Clifton D. Bryant and Dennis L. Peck's anthology, 21 st Century Sociology: A Reference Handbook (2005). Picking up again on Sandra Harding's work, Doucet and Mauthner (2005) delineate a number of key elements of feminist empiricism, including problematizing issues of "power, knowing, representation, reflexivity, and legitimation" (p. 42). Complementary to the above discussion of anti-colonial methodologies is the understanding that researchers, or 'knowers,' are not simply individuals but belong to epistemological communities; a certain reflexivity of these values can critically problematize the researcher's own subjectivities and motivations. This is especially important in critical, poststructural, and anti-colonial inquiry because "the strong claim for socially situated knowledges translates into a greater attention to the concept of reflexivity and to the role of the researcher in constructing knowledge" (Doucet \& 
Mauthner, 2005, p. 38). Specifically relevant to my project is the awareness that "all observation, facts, and findings are value-tinged and that value judgments play a critical role in rigorous empirical inquiry" (Doucet \& Mauthner, 2005, p. 37). Importantly, as Beverly Skeggs notes, feminist research "begins from the premise that the nature of reality in western society is unequal and hierarchical" (as cited in Doucet \& Mauthner, 2005, p. 40). Arvin, Tuck, and Morrill (2013) add further nuance to this articulation; particularly significant to my project, they theorize that because settler colonialism is a gendered process, it is imperative that scholars "[attend] to the links between heteropatriarchy and settler colonialism” (p. 9). While my project does not explicitly confront the links between heteropatriarchy and settler colonialism, I have articulated elsewhere (page 11) that that I understand settler colonialism as a structure that interacts with, depends upon, and upholds hegemonic social structures like heteropatriarchy, capitalism, white supremacy, and ableism, for example.

In another methodological vein, Dhamoon (2009) presents another key feminist contribution to my methodology in her work, Identity/difference politics: How difference is produced and why it matters. Here, she delineates a method of analysis that focuses on contextualizing "how difference is produced, organized, and regulated, and what effect these meanings of difference have on social hierarchies" (p. 11). To accomplish this, Dhamoon initially offers an overarching critique of liberal multiculturalism by asserting that this lens does not properly address identity/difference politics. In particular, Dhamoon argues that liberal multicultural theory obscures issues of power in three ways: it evades analyses of white supremacy, colonialism, and racism through discourses of diversity (p. 6); it also adopts an assimilationist agenda that requires 'different' cultural groups adopt the values of the dominant culture while "downplaying its historical relationship to imperial and colonial ideas" (p. 7); and 
third, liberal multiculturalism assumes the legitimacy of the state, its practices of governance, and its ability to manage culturally different individuals (p. 7). Dhamoon's work is significant to my project because it critiques the neoliberal multicultural context from which my corpus has emerged from. Dhamoon's analytic framework explicitly links the role of discourse in perpetuating hegemonic power structures like capitalism, patriarchy, heteronormativity, ableism, and white supremacy. Specifically, an awareness of identity/difference politics sheds light on the ways in which the government is able to sharply distinguish itself from Indigenous communities, how this difference inherently validates the government's ability to not only dictate Indigenous identities and occupy their land, but also definitively contain the recognition of these entitlements within its own violent institutional framework.

In addition, Dhamoon notably asserts that "discourse [...] shapes the actual lived experiences of people, and social structures shape discourse. Given this, radical social change on the level of discourse effects social change on the material level, and vice versa" (p. 13). Informing my research, her analytic framework critically examines "how meanings of difference are produced, organized, and regulated through power, and the effects of these meanings on socio-political arrangements" (p. 2). Importantly for me, Dhamoon's framework thus draws an explicit linkage between the use of rhetoric and the perpetuation of the entrenched power systems that are intricately tied to maintaining settler colonialism in Canada. Specifically, by addressing how power is indeed bound to discourse in this way, her work helps uncover how a seemingly progressive, neoliberal concept like reconciliation is indeed very active and complicit in maintaining settler colonial hegemony in Canada. 


\section{Critical Communications and Policy Review}

In seeking to apply these epistemologies to guide my methodology, I turn to Lazarsfeld's influential work on distinguishing between administrative and critical communications research. In essence, Lazarsfeld argues that while administrative policy research is "an investigation of a problem delimited by a sponsoring agency, aiming to ameliorate its functioning” (Katz \& Katz, 2016, p. 8), critical research seeks to uncover larger systemic issues often related to power dynamics and competing interests, for example. Administrative research is often commissioned by a sponsoring agency, like the Department of INAC or the federal government in the context of my project, and takes policies and decisions "at face value" (Katz \& Katz, 2016, p. 9). Very much a critical communications project, my project explores the intersection between political communication and public discourse by examining both governmental communications in policy and public-facing news releases.

In order to accomplish this objective, my policy review, informed by feminist and anticolonial methodologies, consists of situating the processes within relevant sociohistorical context and drawing on critical scholarship to articulate the limitations of the respective frameworks. In the context of government communication, Maria Jose Canel and Karen Sanders (2012) articulate that "governing necessarily involves constant exchanges of information and communication about policies, ideas and decision between governors and the governed" (p. 86). As a particular site for political communication, I understand INAC news releases to be publicfacing articulations of both policy decisions/governmental decision-making and political strategy. Access to government communications is crucial in order to explicitly link the federal government's intentions (political strategy) with its actions (policy outcomes). Here, government communications refers to top-level executive communications and is "contrasted with the 
deliberative communication [that] legislatures use to decide public policy through determining the law" (Canel \& Sanders, 2012, p. 86). In practical terms for my project, internal ministerial briefings are the form of government communication that would most clearly link policy with political strategy. Unfortunately, these documents are confidential.

In considering other appropriate communication forms for my analysis, I had originally intended to analyze ministerial mandate letters to trace discursive trends and unearth the emergence of reconciliation discourse in the Canadian political landscape. This idea was inspired by Prime Minister Justin Trudeau's public relations move to transparently publish these documents online since taking office in 2015. Yet, through a fruitless Access to Information and Privacy Request, I learned that all previous mandate letters are cabinet confidences and therefore remain confidential for a century. As an accessible alternative to analyzing INAC mandate letters, I decided to conduct a critical policy review alongside a CDA of public news releases as a way of connecting discourses in political strategy with public communications. I find this particular site of analysis interesting because, different from overt political advertising and marketing, INAC public news releases are widely understood to be communicating policy decisions or settlements, for example, that are based on court rulings and laws. Yet, as my analysis articulates, political strategy is indeed woven into these news releases and reflect the same hegemonic ideologies upon which the Canadian state is built and upheld. I could have gone further to analyze press coverage of these policies, but these documents would no longer directly reflect the government's vision for reconciliation and would deal too explicitly with public opinion.

Situated within the broader framework of political communication, this project is concerned with "the communicative aspect of power and how it may influence communal 
relations" (Stuckey, 2018, p. 1268). Picking up on this notion, I turn to Democracy and Expertise: Reorienting Policy Inquiry by Frank Fischer (2009), which explores the function of narratives and storylines within policy discourse. Operating as a conceptual approach to my analysis, Fischer (2009) explains that narrative storytelling occurs in policy discourse just as it occurs in many other aspects of daily life and "is designed not just to persuade people intellectually but emotionally as well" (p. 191). Importantly for Fischer (2009), narratives allow "people [to] access social positions in their communities, understand the goals and values of different social groups, and internalized social conventions" (p. 197). This perspective is useful for my own research, because as Fischer (2009) continues, policies are not "simply storylines; they are presented more formally as rules and regulations. But the rules and regulations rest on narrative explanations. They reflect particular narrative stories about how the society works, how it should work, and what sorts of measures are needed to make it work that way" (p. 192). This is interesting for my project as it is not strictly an analysis of policy documents, but rather could be a particularly germane site for identifying and critically analysing the form and function of different narratives that the government wishes to circulate through public news releases related to reconciliation.

To this end, sensitivity to narrative storytelling in INAC news releases could help question the function or goal of these documents as political communication; as Fischer (2009) highlights, "at the cultural level, this work [focuses] on the ways narratives serve to give cohesion to shared beliefs and the transmission of basic values" (p. 194-95). This awareness thus raises many critical questions in my work such as: what are the dominant narratives present in individual documents? How to these specific narratives fit within a larger neoliberal and multicultural discussion of values and Canadian identity? Which voices are privileged in these 
narratives? How do these narratives in turn contribute to the ongoing theft of Indigenous land?

By questioning the manner in which these "sequential components [are threaded] together through storylines, narratives place social phenomena [like reconciliation, for example] in the larger patterns that attribute social and political meaning to them" (Fischer, 2009, p. 197).

Furthermore, building specifically on Dhamoon's aforementioned framework, Fischer considers the implications of adopting a cultural politics lens to critical policy analysis. Notably, he emphasizes:

Through an analysis of discursive practices, it focuses, for example, on how particular discourses and narratives make some things important and others insignificant, how they include some participants and exclude or marginalize others. Moreover, where traditional political analysis separates politics and culture, cultural politics denies the separation. (Fischer, 2009, p. 249)

These considerations work hand-in-hand with the conceptual understanding of policy discourse as socially constructed and operationalized through narrative storylines. The cultural politics lens is thus crucial to include in my work because I am seeking to explore the "signifying practices through which identities, social relations, and rules are contested, subverted, and possibly transformed" (Fischer, 2009, p. 249) in policy and practice through reconciliation discourse in INAC news releases. My work seeks to elucidate how these signifying practices, "although less visible and often latent, [are of primary concern] underlying and shaping the other more visible and manifest topics and issues under discussion" (Fischer, 2009, p. 249)-- topics like reconciliation, for example.

Moreover, Fischer ties together this critical discussion of power with the understanding that public policy is socially constructed by problematizing it as value-laden and inherently politically-motivated discourse. Importantly for my project, his work seeks to "make explicit the less visible discursive power configurations that permeate and produce [social spaces]" (Fischer, 
2009, p. 250). As such, in a broad sense, it is indeed necessary to understand my research as operating within a socially constructed understanding of Canada as a nation. Because my site of research is the federal Department of INAC, its policies, and the public news releases that it publishes, there is a certain reality that is being produced and taken for granted here: the common sense settler colonial occupation of the lands now known as Canada. And as Fischer (2009) states, "policy processes are entirely interwoven with dominant and competing systems of social meaning" (p. 170). To this end, neoliberal discourses of multiculturalism and reconciliation are now prominent characteristics of Canada's national identity and contribute to the construction of colonialism as historical and well-rooted in the past rather than as an ongoing project $^{14}$. Consequently, Fischer (2009) articulates that "many of the ideas and social understandings upon which [our] world [is] constructed are so deeply embedded in the societal institutions and practices that they are difficult to recognize or identify." (p. 169).

To address these issues, Fischer delineates the form and function of a number of problematic discursive maneuvers in the policymaking process that facilitate the perpetuation of hegemonic norms and assumptions. Notably, Fischer (2009) points out the importance of recognizing that "ambiguous meanings often have important political functions" (p. 175). This is key to my findings as I argue the concept of reconciliation is deliberately left ambiguous in government-issued public news releases in order to serve different purposes depending on the context. Ambiguous meaning is thus one significant rhetorical move to address in my coding process, for example. Fischer (2009) continues, "by helping to bring together citizens with varying policy preferences, ambiguous meanings often facilitates cooperation and compromise. Enabling politicians to blur or hide problematic implications of controversial decisions,

${ }^{14}$ I expand upon this critique on pages $86-92$. 
ambiguity can assist in sidestepping barriers that otherwise block consensus-building” (p. 175). As such, I pay particular attention to the function of the ambiguous meanings of reconciliation, for example, in both my policy review and coding process in order to perhaps identify how, why, in what context, and to whose benefit the concept of reconciliation is able to shape-shift rhetorically, and in turn practically through policy outcomes like land claims settlements and self-government agreements.

\section{Methods for Critical Discourse Analysis}

Applying these methodological insights to my own method of empirical research, I turn to Grbich (2013), who distinguishes between two schools of thought for discourse analysis: the Foucauldian approach and CDA. While Foucault was concerned with the production of culture, knowledge, and power through discourse, he was careful not to be to prescriptive in how an analyst would accomplish this. Norman Fairclough, however, expanded on Foucault's approach and developed it to specifically include linguistic analysis as a means of shaping and enacting social structures and practices (Grbich, 2013, p. 251). At its core, Fairclough's approach to CDA operates at three levels: textual analysis of syntax and lexical choices (micro); identifying processes of power relations through discourse production (meso); and understanding specific events as "instances of sociocultural practice" (macro) (Grbich, 2013, p. 252). Therefore, this is a fitting method for my empirical research as my textual analysis seeks to expose the systems of power that are reproduced through discourses of reconciliation as a particular instantiation of a 'sociocultural practice,' which, in this instance, I understand to be settler colonialism.

Building on Fairclough's principles, Thomas Huckin divides CDA guidelines into two main steps and produces a practical outline for carrying out this method: identifying framing and interpretation. As a first step, Huckin suggests reading the text in a general manner before 
reading it more critically and identifying structural particularities in the text and identifying whose voices are included (and whose are excluded) (Grbich, 2013, p. 252). Next, Huckin offers a number of prompts for coding and interpretation, including: paying attention to not only how sentences are structured, but also specifically the use and function of passive verbs and direct/indirect quotes; noting which actors are portrayed as powerful, which are passive, and why; challenging statements that the author takes for granted; identifying moves of connotation, insinuation, and hedging; determining what is the general register of the piece (optimism, scepticism) (Grbich, 2013, p. 252). As such, Huckin's outline is indeed very useful in framing my initial coding process ${ }^{15}$ as it will allow me to identify important rhetorical moves at the micro and meso level of the INAC texts in order to provide a well-informed, macro-level commentary on the reproduction of settler colonial governance in Canada.

An important resource for my method is Canadian social work scholar and settler Robert Harding, who has been examining representations of Indigenous peoples in Canadian news media for almost fifteen years. In his 2005 article, "The Media, Aboriginal People and Common Sense," Harding explores the use of stereotyping by the media to manage their readers' interpretation of news items related to Indigenous peoples in Canada by using techniques of content analysis. His most recent article, "Controlling Land: Historical Representations of News Discourse in B.C.," Harding (2017) operationalizes a CDA of news coverage of the Nisga'a 1998 referendum and the 2002 BC Treaty Referendum to delineate how the media frames Indigenous peoples as "a threat to settler interests and values" (p. 65). Although Harding focuses on a different site of analysis than my own work-- that is, news media rather than publicly-issued government policy statements-- the narratives operationalized in these discourses are not

\footnotetext{
15 See Appendix I.
} 
necessarily unrelated; as Harding (2005) argues, "in framing Aboriginal issues in ways that effectively deny or denigrate the inherent rights of Aboriginal people, the media exert a powerful and direct influence on public policy towards them and indirectly on their lives" (p. 314).

In addition to being within the same general research area as my work, Harding clearly delineates his process for carrying out the content analysis in "The Media, Aboriginal People and Common Sense." This outline is thus a particularly germane foundation upon which I can build my own coding process. For example, he lists twelve overarching questions that function to help identify the "major patterns, themes and trends" that emerge in his corpus through the course of his research (Harding, 2005, p. 317). While questions like "What Aboriginal topics are covered most frequently? Least frequently?" and "What is the identity of Aboriginal primary actors (e.g. First Nations, Metis or Inuit)?” (Harding, 2005, p. 317) raise more surface-level details about the text itself, this information may be useful, as Harding mentioned, in identifying more macrolevel themes and patterns. Moreover, he also outlines the coding sheet he used for examining each article. Divided into five sections (publication details, Aboriginal topics present, actors and roles, Aboriginal identity of Aboriginal actors, and other attributes), Harding's coding sheet (2005, p. 319) is adaptable and useful to my project. Though not inherently critical or related specifically to themes of reconciliation, these coding prompts, much like the research questions listed above, can potentially provide useful contextual information by "[recording] and [counting] basic manifest features of the content under study [and] [incorporating] interpretive analysis of latent content" (Harding, 2005, p. 320). To this end, while Harding does indeed articulate that power relations operate in news discourse, he does so almost in passing in this article. As such, the scope of his content analysis is limited in its ability to critically assess the effect of 'common sense' stereotyping on managing and containing Indigenous identities in the 
media. To this end, Harding's methodological framework is a rich starting point for outlining my own method; I focus less on the quantitative-type data that an analysis of manifest content produces and focus more so on critically engaging with how power is wrapped up within rhetorical, latent content.

In another article, however, Harding (2017) explicitly operationalizes techniques of CDA to "expose the racist logics and rhetorical strategies mobilized in support of dominant colonizing discourses" (p. 68). By focusing on lexical structures and use of rhetorical devices like metaphors and hyperboles, Harding (2017) identifies four main rhetorical arguments used by news media to frame "Indigenous peoples as a threat to Euro-Canadian interests and values" ( $p$. 69): appropriation, classification, debasement, and affirmation. These rhetorical strategies offer important insight for my work and help to identify more power-related, qualitative criteria for my latent coding framework like moves based on moral imperatives and "apparent praise," which serve to reproduce paternalistic attitudes of Western superiority. In particular, Harding (2017) speaks about how the media essentializes the position of Indigenous peoples unanimously supporting treaty negotiations, while excluding the voices of the many Indigenous scholars and leaders who "believe that such treaties [...] simply perpetuate the current postcolonial relationship between Indigenous peoples and settler governments" (p. 70). Most notably, however, Harding discusses discursive strategies that serve to decontextualize the treaty process and perpetuate ahistorical conceptualizations of land claims. Harding (2017) delineates how paying attention to lexical choices like verb use can even expose these attitudes:

'Give', a lexical choice used to describe Nisga'a compensation [...] suggests that this was a one-way process in which one side received expensive 'gifts' and nothing in return. Yet 'give' more accurately describes the actions of the Nisga'a, since the treaty resulted in the Nisga'a giving settlers 90 percent of their territory and receiving nothing they didn't already possess in the first place. (p. 77) 
These lexical choices are also related to the colonial trope of appropriation, which assumes that settlers have a right to this land. Important to my work, moveover, Harding (2017) even discusses how "even those journalists who positioned themselves as 'sympathetic' to Indigenous peoples accepted basic colonial premises-- namely, that Indigenous peoples are entitled to a mere fraction of their traditional territories and that they be afforded only a limited form of selfgovernment" (p. 85). An awareness of these rhetorical moves is indeed crucial to my empirical research as it is able to identify the underlying attitude present in all land claims settlements and self-government agreements between the Federal government and Indigenous communities: these frameworks are unequivocally contained within settler laws. Thus, while the work comes from a different site of analysis (news media vs. government-issued public news releases), it is apparent that Harding's CDA in "Common Sense" provides me with another important reference for developing my coding framework and method, which can be found in Appendix 1 (pp.100). 


\section{Chapter 3: Theoretical Perspectives}

In order to interrogate how reconciliation discourse is operationalised to uphold settler colonial occupation in political communications, my project refers to four main strands of theoretical perspectives, which mostly emanate from prominent, contemporary Indigenous thought. As outlined at length below, these theories and perspectives work together in the background of my project to elucidate how settler colonialism is reproduced and validated at the discursive level through reconciliation discourse in both land claims and self-government policies and INAC public-facing news releases. Firstly, I draw on Coulthard's work in Red Skin, White Masks (2014) to delineate the politics of rights recognition in the context of the historical and ongoing dispossession and displacement of Indigenous bodies from their lands. In the context of Coulthard's recognition paradigm, I then turn to Alfred and Corntassel's (2005) discussion on the politics of distraction. The theories that are reviewed in these first two sections speak more to the ways that these policies are understood to impact Indigenous peoples, and are less concerned with both the function of public discourse and its impact on public opinion. While Coulthard, Alfred, and Corntassel theorize about the ways Indigenous groups engage with colonial policies and the effect of this recognition on communities, my policy review and discourse analysis focus on the ways colonial processes uphold hegemony through political strategy.

With this in mind, moreover, I then draw on Foucault's work on governmentality to help elucidate how reconciliation, like recognition and distraction, is in fact the product of a larger 'governing mentality' that seek to "recuperate and not interrupt settler colonialism" (Tuck \& Gaztambide-Fernandez, 2013, p. 80) to ensure settler futurity. This logic works in contrast with my last theoretical contribution, Simpson's (2011) influential work on Indigenous resurgence, 
because it further highlights the necessity of working outside of colonial frameworks. This is an important strand of thought to my project because it not only fundamentally challenges and rejects settler hegemony, but it also calls attention to the importance of centring land and community in decolonizing efforts. My project seeks to problematize the underlying logic of settler governmentality in the context of Indigenous resurgence for the purpose of understanding how reconciliation, as a colonial tool of assimilation, operates within Coulthard's recognition paradigm. Overall, I argue this logic serves to further substantiate settler colonial governance by enticing Indigenous communities to 'buy-in' to State recognition, attempting to effectively neutralize efforts of resurgence and decolonization. 


\section{Recognition Paradigm}

Coulthard's work in Red Skin, White Masks (2014) is a foundational theorization to my analysis overall. Truly a seminal work in Indigenous political thought, Coulthard conducts a close reading of Franz Fanon's Black Skin, White Masks (1952) to effectively delineate the recognition paradigm in Canada: the notion that "the Canadian state depends on the ability to entice Indigenous peoples to identify, either implicitly or explicitly, with the profoundly asymmetrical and nonreciprocal forms of recognition either imposed on or granted to them by the settler state" (p. 25, emphasis in original). At its core, Coulthard (2014) theorizes that the politics of recognition encompasses "the now expansive range of recognition-based models of liberal pluralism that seek to 'reconcile' Indigenous assertions of nationhood with settler-state sovereignty through accommodation of Indigenous identity claims in some form of renewed legal and political relationship with the Canadian state" (p. 3). This assertion is crucial to my project because, as I first set out to focus the site of my analysis, the contents of my data set (INAC public news releases that engage with reconciliation discourse) were invariably entangled within this politics of recognition; the identity claims Coulthard actually examines in his analysis-- those are: land claim settlements, economic development initiatives, and selfgovernment agreements-- effectively encompass the main organizing themes I originally pulled from my corpus. Specifically, my analysis focuses on land claims settlements and selfgovernment agreements and I argue that strong relation between the contexts of his analysis and my project is not coincidental, but rather speaks to and buttresses the idea that identity claims made through state-sanctioned rights recognition occur in the name of reconciliation and function as a colonial tool of assimilation. He challenges "the increasingly commonplace idea that the colonial relationship between Indigenous peoples and the Canadian state can be 
adequately transformed via such a politics of recognition" (Coulthard, 2014, p. 3). Simply put, reconciliation discourse works through recognition politics in federal policy to maintain and further entrench the inherently asymmetrical relationship between Indigenous peoples and the Canadian state because it does not fundamentally address the historical and ongoing theft of Indigenous land on Turtle Island ${ }^{16}$.

Furthermore, by engaging with Fanon's work, Coulthard (2014) elucidates how these policies have "made the transition from a-more-or-less unconcealed structure of domination to a mode of colonial governmentality that works through the limited freedoms afforded by state recognition and accommodation" (p. 15-16). To this end, Fanon's analysis aptly articulates that "in contexts where colonial rule is not reproduced through force alone, the maintenance of settler-state hegemony requires the production of [...] 'colonized subjects"' (Coulthard, 2014, p. 16), who essentially uphold the colonizer-colonized power dynamic by engaging in colonial practices and subject positions that require their continued domination. This speaks to the important idea that colonialism operates on two levels of recognition: both structurally and psychologically. Essentially, the desire and consequent action to seek institutional rights recognition within Canadian legal frameworks inherently maintains the subordination of Indigenous peoples vis-a-vis the Canadian state because these desires and actions are premised

\footnotetext{
${ }^{16} \mathrm{NB}$ : as Mi'kmaw scholar Bonita Lawrence discusses, federal rights recognition in the land claims process not only ideologically disrupts Indigenous nations' identity claims by situating these claims firmly within the colonial purview, but also fails to consider the ongoing effects of colonial powers forcefully dividing Indigenous communities through both treaty boundaries and political and provincial lines, for example. What is more, she articulates that the land claims process functions to further fracture some already-splintered communities. For example, in the context of the Algonquins of Ontario, Lawrence (2012) delineates how "some of the divisions that currently plague some of the federally unrecognized Algonquin communities originated when the land claim negotiators from Pikwakanagan disregarded the organizations that pre-dated the land claim" (p. 6). For a more nuanced discussion, read Lawrence, B. (2012). Fractured homeland: Federal recognition and Algonquin identity in Ontario. Vancouver: UBC Press.
} 
on the underlying notion that the State is indeed the sole source for valid rights recognition. And, as Coulthard (2014) continues, "the terms of accommodation usually end up being determined by and in the interests of the hegemonic partner in the relationship" (p. 17). Thus, settler colonialism has been crafted in Canada to appear natural and common sensical through structures and institutions, which in turn work to perpetuate Indigenous peoples' internalized subordination. Furthermore, case law in Canada indeed proves that "colonial powers will only recognize the collective rights and identities of Indigenous peoples insofar as this recognition does not throw into question the background legal, political, and economic framework of the colonial relationship itself" (Coulthard, 2014, p. 61). Recognition, then, fundamentally limits the possibility of freedom for Indigenous peoples, as this freedom is necessarily contained within settler colonial governmentality and is "grounded in the assumption that Indigenous rights are subordinately positioned within the ultimate sovereign authority of the Crown" (Coulthard, 2014, p. 123). These concepts are crucial in my discussion of reconciliation discourse, like recognition, reconciliation remains "committed to the dispossession of Indigenous peoples of [their] lands and self-determining authority" (Coulthard, 2014, p. 151). As the above discussion highlights, and much of the discussion below will expand upon, these concepts are indeed intertwined with colonial tools of assimilation like land claims and self-government processes.

\section{Politics of Distraction}

Building on Coulthard's insights, I refer to Alfred and Corntassel to further highlight the problematic nature of Indigenous folks turning to the state for rights recognition in their piece "Being Indigenous: Resurgences Against Contemporary Colonialism" (2005). Alfred and Corntassel (2005) problematize the underlying issues of Indigenous peoples seeking political and legal recognition through state-sanctioned, colonial identity constructions in their discussion of a 
politics of distraction, whereby they maintain that this is an effective way for the state to divert "energies away from decolonizing and regenerating communities and [frame] community relationships in state-centric terms" (Alfred \& Corntassel, 2005, p. 600). Essentially, Alfred and Corntassel (2005) argue that the state's primary motivation in expanding Indigenous peoples' political/legal rights in Canadian law are to "gradually subsume Indigenous existence into its own constitutional system and body politic" (p. 598), which further solidifies its unfettered access to Indigenous land. This speaks to Coulthard's assertion that recognition fundamentally limits Indigenous peoples' freedom. What is more, Alfred and Corntassel (2005) go on to name these colonial narratives of recognition as 'shape-shifting colonial powers,' which are crucial "instruments of domination [that] are evolving and inventing new methods to erase Indigenous histories and senses of place" (p. 601). These insights are helpful in the context of my project because it is important to not only delineate how recognition and reconciliation work together, as I've done with Coulthard's work, but also understand how this recognition impacts Indigenous communities through the politics of distraction. In seeking recognition from the government, "this continuing colonial process pulls Indigenous peoples away from cultural practices and community aspects of "being Indigenous"” (Alfred \& Corntassel, 2005, p. 599). To this end, reconciliation discourse functions within discussions of land claims and self-government processes, for example, to "sap the crucial energy and solidarity that are essential to effective confrontation of imperial power in whatever form it presents itself' (Alfred \& Corntassel, 2005, p. 603). It is through this understanding that we can appreciate why a community- and landcentred alternative to state-sanctioned rights recognition is necessary for Indigenous resurgence: state recognition not only severs "Indigenous links to their ancestral homelands" and creates 
divisions in the community, but it also fundamentally distracts decolonial efforts for selfdetermination by framing the conversation around rights, rather than responsibilities.

Furthermore, this distinction between rights/responsibilities is picked up by Corntassel in his piece "Towards Sustainable Self-Determination: Rethinking the Contemporary IndigenousRights Discourse" (2008), where he further demonstrates the limits of existing rights discourse for Indigenous peoples in the context of recognition and reconciliation. With Coulthard's critiques of recognition still in mind, Corntassel (2008) agrees that states deliberately frame selfdetermination narrowly by containing the narrative within state political/legal recognition, and goes on to argue that seeking this recognition is also detrimental because it effectively diverts "energies away from more substantive discussions regarding the reclamation of Indigenous territories, livelihoods, natural resources, and the regeneration of community languages and culturally-based practices" (p. 107). By creating a distinction between land rights and political rights, discussions about self-determination are effectively divorced from "cultural responsibilities and relationships that Indigenous peoples have with their families and the natural world" (Corntassel, 2008, p. 107). To this end, recognizing the imperative to move past seeking rights-based recognition from the settler colonial state to a responsibility-based relationship to community is crucial in addressing the politics of distraction; Corntassel (2008) importantly articulates that "in order to reposition Indigenous peoples philosophically and politically in a movement for community, family, and individual regeneration, it is critical to begin with Indigenous community-based responsibilities in order to open new pathways for sustainable selfdetermination" (p. 121). This community-based framework decentres the "narrowly constructed, state-driven discourse toward a responsibility-based movement centered on a sustainable selfdetermination process" (Corntassel, 2008, p. 124). 
Essentially, while my multi-method analysis speaks to the limitations of state-led land claims and self-government processes in the context of reconciliation discourse, these theoretical foundations supports these limitations but from the context of Indigenous scholars' critiques of state-led recognition. These two pieces work in conversation with Coulthard's recognition paradigm and are thus important theoretical contributions for my project; the politics of distraction is a useful contribution for expanding on Coulthard because it frames the conversation in land- and community-centred terms. Moreover, this theory can be effectively applied to discourses of reconciliation because as I've outlined above, reconciliation politics indeed converges with the politics of recognition: "the institutional recognition and accommodation of Indigenous cultural difference as an important means of reconciling the colonial relationship between Indigenous peoples and the state" (Coulthard, 2014, p. 106). Therefore, the discussion of distraction complements that of recognition by not only delineating how and why reconciliation discourse is so problematic in the context of true self-determination and decolonization, but also by paving the way for the next theoretical contribution: settler governmentality.

\section{Settler Governmentality}

Speaking briefly to the concept of governmentality, I turn to Foucault's 1978-1979 lecture series where he initially semantically links "governing (gouverner) and modes of thought (mentalité)" (Lemke, 2002, p. 50) in order to study the technologies of political power. In this context, he differentiates between power, government, and domination; whereas domination "refers to those asymmetrical relationships of power in which the subordinated persons have little room for manoeuvre" (Lemke, 2002, p. 53) and is considered a technology of government, this technology is responsible for the "systematization, stabilization, and regulation of power 
relationships" (Lemke, 2002, p. 53). In this line of inquiry, he problematizes governmentality as encompassing both "microphysics of power with the macropolitical question of the state" (Lemke, 2002, p. 58). To this end, and importantly for my project, Foucault's discussion of neoliberal governmentality "shows that the so-called retreat of the state is in fact a prolongation of government: neoliberalism is not the end but a transformation of politics that restructures the power relations in society" (Lemke, 2002, p. 58). This is crucial to my discussion of reconciliation discourse because, especially in the context of land claims settlements and selfgovernment agreements because while on the surface level, these processes appear to be enshrining more rights and more freedoms for First Nations, Métis, and Inuit communities, they are truly neoliberal tools of governmentality that fundamentally maintain federal domination over these communities. These tools of governmentality work through recognition and distraction to promote the idea that decision-making power is devolved from the government and being returned to Indigenous communities, when in reality these tools are extensions of state control. While this recognition is tightly contained within neoliberal, colonial governmentality, it is nonetheless a limited form of state-sanctioned self-determination and is narrowly depicted in my corpus as a mutually-beneficial project for both Indigenous communities and the Canadian state. Accordingly, following Foucault, this is not a "diminishment or reduction of state sovereignty and planning capabilities but a displacement from formal to informal techniques of government" (Lemke, 2002, p. 58). The result, much as we see is the case in Canada with the federal downloading of responsibilities onto communities through these various agreements, is that Indigenous individuals and communities are rendered responsible for "social risks such as illness, unemployment, poverty, and so forth, and for life in society" (Lemke, 2002, p. 59). 
Andrew Crosby and Jeffrey Monaghan speak specifically to colonial governmentality in Canada in their article, "Settler Governmentality in Canada and the Algonquins of Barriere Lake" (2012). Here, they argue that the term settler colonial governmentality aptly reflects "the particular rationalities of governance that animate Canada's relationship with, and governance of, Indigenous peoples" (Crosby \& Monaghan, 2012, p. 422). Speaking to Patrick Wolfe's aforementioned logic of colonial elimination, this article serves to "illustrate [the] eliminatory rationality of settler governmentality" (Crosby \& Monaghan, 2012, p. 423) that aims towards negating colonial status through various governmental interventions. This is useful in my project's discussion of reconciliation discourse because this elimination logic is woefully apparent in the government's recognition of Indigenous rights through land claims and selfgovernment agreements, for example. In further recognizing Indigenous rights in Canadian constitutionality, these agreements serve to reduce the overtly colonial and asymmetrical relationship between Indigenous peoples and the federal government on the surface, while in fact leaving the structures of colonial domination-- and thus the logics of hegemonic governmentality-- in tact. Notably, this logic also contributes to "a governing rationality that aims to eliminate competing sovereignties under its exclusive jurisdiction" (Crosby \& Monaghan, 2012, p .425). Consequently, Crosby and Monaghan (2012) importantly assert that "settler governmentality is the underlying framework for governing Indigenous peoples" in Canada (p. 425). My project aims to reveal how discourses of reconciliation are indeed very much a part of colonial governmentality that is ultimately "used to assist an overriding objective aiming to dispossess and repossess Indigenous lands" (Crosby \& Monaghan, 2012, p. 425). Moreover, speaking directly to the logic outlined above by Coulthard's (2014) recognition paradigm in land claims agreements, for example, "while removing Indigenous barriers to 
accessing land, settler governmentality in Canada relies upon colonial tools of dispossession while simultaneously constructing its own post-colonial narrative to celebrate itself as a new nation that is free from the colonial past" (p. 425). These 'post-colonial narratives' are indeed prevalent in my corpus of INAC news release materials, discussed fully in Theme 3 of my analysis (pp. 87-92).

\section{Indigenous Resurgence}

A final, crucial layer to my project's theoretical foundation comes from Simpson in her influential work Dancing on Our Turtle's Back (2011) where she encourages Indigenous communities to reject the colonial politics of recognition, and the politics of distraction, and refocus toward community-centred resurgence. Notably, Simpson (2011) emphasizes that transformative change will occur when communities return to Indigenous contexts of knowledge, interpretations, values, ethics and processes (p. 17). She maintains that this imperative must occur in the communities' own terms, "without the sanction, permission or engagement of the state, western theory or the opinions of Canadians" (Simpson, 2011, p. 17). Moreover, Simpson (2011) characterizes her understanding of Indigenous resurgence as the rebuilding and regenerating of political and legal traditions, language learning, ceremony and spiritual pursuits, and nurturing artistic and performance-based traditions (p. 17). For Simpson, "the land, reflected in Nishnaabeg thought and philosophy, compels [Indigenous peoples] towards resurgence in virtually every aspect" (p. 18). Importantly, she contends: "we do not need funding to do this. We do not need a friendly colonial political climate to do this. We do not need opportunity to do this. We need our Elders, our languages, and our lands, along with vision, intent, commitment, community and ultimately, action” (Simpson, 2011, p. 17). For Kanaka ‘Ōiwi Hawai'i scholar Hōkūani K. Aikau (2015), Indigenous resurgence works to strengthen and protect these 
connections "while [restoring] Indigenous responsibilities and respect for one another, land, and culture" (p. 656).

This is indeed in stark contrast to the federal government's priorities of Indigenous rights recognition and state-led reconciliation efforts; as Aikau (2015) continues, whereas these rightsbased discussions focus on Indigenous-state relations "through policy, programs, and interventions intended to increase capacity and build resilience" (p. 656), Indigenous resurgence focuses on responsibilities for community. This is a critical insight for my project as, in my corpus, reconciliation is predominantly framed in precisely these terms-- funding, political recognition, and opportunity that aims to 'improve.' Centring resurgence is therefore important to my project as I seek to fundamentally challenge the government's motivations in promoting the concept of reconciliation in mainstream Canadian discourses. Simpson makes it clear that reconciliation is not relevant to Indigenous resurgence; the state, and the state alone stands to benefit from these politics of recognition and institutionalized reconciliation. To this end, she challenges "if reconciliation is focused only on residential schools rather than the broader set of relationships that generated policies, legislation and practices aimed at assimilation and political genocide, then there is a risk that reconciliation will 'level the playing field' in the eyes of Canadians" (Simpson, 2011, p. 22). This is another crucial assertion, as my corpus also highlights the predominance of reconciliation discourse in the context of Indian Residential Schools and the Truth and Reconciliation Commission of Canada (TRC). She makes a compelling argument, that for her, reconciliation must be

Grounded in cultural generation and political resurgence [and] must support Indigenous nations in regenerating $[\ldots]$ languages, $[\ldots]$ oral cultures, [...] traditions of governance and everything else residential schools attacked and attempted to obliterate. Reconciliation must move beyond individual abuse to come to mean a collective rebalancing of the playing field. (Simpson, 2011, p. 22) 
Simpson's (2011) vision is in contrast to seeking recognition within settler colonial institutions, and emphasizes a transformative and revolutionary Indigenous resurgence that recreates "the cultural and political flourishment of the past to support [contemporary] well-being” (p. 51). As this flourishment, or resurgence, is intricately tied to land, it is crucial that my project comes back to the question of land: for Indigenous resurgence to flourish, the continued theft of Indigenous land must necessarily be problematized for the reconnection with their lands.

Because these community-based imperatives work entirely outside of the settler colonial machine, it is also important to name this machine as it is: settler governmentality. To this end, Coulthard (2014) succinctly ties together the recognition paradigm and reconciliation discourse by summarizing Simpson, who asserts that settler colonial rule is indeed a form of governmentality. This governmentality encompasses "a relatively diffuse set of governing relations that operate through a circumscribed mode of recognition that structurally ensures continued access to Indigenous peoples lands and resources by producing colonial subjectivities that coopt Indigenous peoples into becoming instruments of their own dispossession" (Coulthard, 2014, p. 156). Recalling how governmentality works to make the state appear to be devolving power when it is actually further entrenching state power, Coulthard (2014) goes on to thus importantly argue that "according to this view, contemporary colonialism works through rather than entirely against freedom" (p. 156).

In enshrining more rights within the Canadian constitutional order, Indigenous peoples are further implicated in the continued supremacy of settler sovereignty. Conversely, by focusing on Indigenous resurgence and building community, Aikau (2013) maintains that it is then possible to "begin to imagine alternative forms of governmentality that are not predicated on statist models" (p. 657). Resurgence is important to my project, then, as it decentres the 
Canadian state as a source for Indigenous self-determination and fundamentally challenges settler governmentality. 


\section{Chapter 4: Reconciliation as a Shape-Shifting Concept of Colonialism}

In Canada and across the globe, Indigenous and settler thinkers alike have grappled with defining, theorizing, and critiquing the concept of reconciliation for more than a decade. There thus already exists an important scholarly foundation upon which to build my critical analysis. The aim of this section is twofold: first, I will provide an overview of how scholars in the field have been working to define the concept of reconciliation. This first section is not meant to serve as an exhaustive definition, but rather a means of providing contextualization to my project and initiating a critical conversation about its underlying logics. The second half of this section will serve as a review of critical literatures in reconciliation discourses. Here, I will outline the ways in which scholars in the field have already critically approached this topic. Accordingly, I contend that while other scholars have already interrogated many different facets of settler colonial governance in Canada, there nonetheless remains a significant gap in knowledge in the field specifically pertaining to the Canadian federal department most fundamentally tied to Canada's fiduciary responsibility to Indigenous peoples: INAC. To this end, I maintain that not only is this particular research project timely, but it also builds on a rich and well-researched body of literature and makes an important and original contribution to the Settler Colonial Studies and Canadian Studies. 


\section{A Brief Overview of the Concept of Reconciliation in Canada}

In Canada over the last decade or so, the concept of reconciliation has emerged from relative obscurity to become not only a central component of the liberal and progressive mainstream lexicon, but also arguably a centrepiece to Canada's national image on the international stage. However, many Indigenous activists and scholars have been vocal in opposition to reconciliation politics (Coulthard, 2014; Manuel, 2017; Simpson, 2011, 2017; Alfred \& Corntassel, 2005; Corntassel, 2008); as the late Secwepemc leader and scholar Arthur Manuel (2017) articulates, embracing state-sanctioned reconciliatory objectives "gives the world the image that [Indigenous peoples] do not, after all, need self-determination because the colonial system where all [...] land remains under federal and provincial control is working" (p. 202). For most Canadians, however, the increasingly commonplace discussions about reconciliation in the public sphere in Canada is likely a result of the TRC, which operated from 2008 until the Final Report was released in 2015. This claim is supported when comparing results from Environics surveys conducted in 2008 as the TRC was being established and in 2016 after the Final Report was released. Accordingly, the 2008 Environics Benchmark Survey prepared for the TRC highlighted that approximately $67 \%$ of Canadians believed that "individual Canadians have a role to play in efforts to bring about reconciliation in response to the legacy of the Indian residential schools system, even if they had no experience with Indian residential schools" (Environics, 2008, p. 16). By 2016, this number had increased to 84\% (Environics, 2016, p. 35).

But while both settler Canadians and Indigenous peoples are increasingly talking about reconciliation, it still remains a slippery term that is not only difficult to define, but I argue is also left intentionally ambiguous by the government so it may be used in many different contexts 
for many different reasons. This argument will be expanded upon in my Analysis (p. 64-93) and Conclusion (pp. 93-100). For now, however, it is worth noting that there is a vast range in what 'reconciliation' means to scholars, the federal government, INAC and its actors, and most broadly, Canadians. Many scholars agree, on one hand, that the concept of reconciliation is increasingly used as an all-encompassing stand-in for describing Indigenous-settler relations (Clark, de Costa, \& Maddison, 2016; Wylie, 2017; Maddison, 2016; Blackburn, 2007; Henderson, 2010; Davis, Hiller, James, Lloyd, Nasca, \& Taylor, 2017). On the other hand, for example, $20 \%$ of Canadians polled in the 2016 Environics survey understand reconciliation as working toward equality and mutual respect; $18 \%$ see it as making amends through public apology; and 15\% believe it primarily involves forgiveness, closure, and moving forward (Environics, 2016, p. 33). However, Canadian scholar Paulette Regan (2010) argues that overwhelmingly, "when non-[Indigenous] Canadians talk about reconciliation in other than a strictly legal sense, the tendency is to speak solely of the need for [Indigenous] peoples to heal themselves and reconcile with us, so that the country can put this history behind it and move forward" (p. 60). Moreover, while the Government of Canada has an entire area of its website dedicated to reconciliation ${ }^{17}$, this comprehensive corner of the newly-minted CIRNAC website simply lacks any attempt of defining or describing what considers reconciliation means to the Minister, the department, or most broadly, the federal government. This definitional evasion is problematic and, as Manuel (2017) articulates, serves the government's interests by spreading confusion to the public (p. 201). This critique, as well as a number of others, will be picked up in the second part of this section. For now, as a first step towards contextualizing the meaning of reconciliation in Canada, I will organize these literatures into two distinct baskets: political

${ }^{17}$ See https://www.rcaanc-cirnac.gc.ca/eng/1400782178444/1529183710887. 
reconciliation in the context of Section 35 constitutional and legal rights, and cultural reconciliation in the context of the TRC as a consequence of the Indian Residential School Settlement Agreement (IRSSA).

While it is clear that as a result of the TRC and its 94 Calls to Action, the vast majority of Canadians feel increasingly implicated in the reconciliation process (whatever that might be), reconciliation emerged discursively and politically in Canada well over 30 years ago. Tom Clark, Ravi de Costa, and Sarah Maddison (2016) theorize that while reconciliation first appeared in "societies transitioning from periods of authoritarian rule or civil war," the concept has since been operationalized in settler colonial states such as Australia and Canada (p. 2). In the Canadian context, reconciliation appeared as a consequence of the inclusion of 'Aboriginal and treaty rights' within Section 35 of the repatriated Canadian Constitution in 1982. In this instance, the term is used in a legal sense that seeks to reconcile Indigenous customs and laws with "the unilateral assertion of Crown sovereignty" (Turner, 2013, p. 111). This essentially recognizes that Indigenous peoples lived on these lands in distinctive societies with cultures, traditions, and customs prior to European contact and thus the Aboriginal rights recognized and affirmed in Section 35 seek to reconcile "the pre-existence of Aboriginal societies with the sovereignty of the Crown" (Wylie, 2017, p. 618). To this end, echoing the work of Coulthard (2014, p. 107), Australian scholar Sarah Maddison (2016) contends that because the constitution is an expression of a state's sovereignty, constitutional reform that recognizes Indigenous rights results in not only further legitimizing the settler state's sovereignty, but also does so through a nation-building narrative of reconciliation, which aims to "direct attention toward processes intended to overcome past divisions and replace them with a sense of shared nationhood" (p. 5). This critique is particularly salient in the context of my project because it not only problematizes 
reconciliation within Coulthard's recognition paradigm, but it also alludes to the politics of distraction. In the specific context of Section 35, reconciliation is problematic both because it is premised on constitutional recognition of Indigenous rights, which validates colonial sovereignty, but also because it perpetuates the illusion that colonial violence is simultaneously firmly located in the past and forgiven in the name of 'renewed relationships,' for example.

This interpretation of reconciliation as a political and legal concept was further developed through significant case law in the late 1990s with $R v$. Gladstone (1996), $R v$. Van der Peet (1996), and Delgamuukw v. British Columbia (1997), which accepted Indigenous oral histories as evidence, but ultimately maintained the unequivocal authority of the Canadian state (Turner, 2013, p. 108). These court decisions occurred following the release of the RCAP final report in 1996, which offered an insightful vision of reconciliation between Indigenous peoples and settlers "based on the core principles of mutual recognition, mutual respect, sharing and mutual responsibility" (Coulthard, 2014, p. 119). To this end, it is now understood that the concept of reconciliation outlined in RCAP more closely aligns with Indigenous visions of transitional justice and serves to bridge historical and ongoing violences rather than to decisively construct them as historical events (Wylie, 2017, p. 620). However, in the wake of RCAP, the Canadian government began promoting primarily affective conceptions of reconciliation (James, 2017, p. 379) in tandem with the political understanding outlined in Section 35. These understandings, however, not only received more attention than RCAP's substantive vision, but also essentially “severed the concept from RCAP's emphasis on land, powers, and governance, and tethered it to residential school apologetics instead" (James, 2017, p. 369). Canadian scholar Michael McCrossan (2013) works to explain this deliberate, discursive shift from substantive to affective reconciliation as it "occurs at the precise moment that [Indigenous] peoples link their rights to 
alternate legal orders" (p. 167) and can be understood as a mechanism to protect Canada from this perceived threat to its integrity as a sovereign nation. Looking back to my discussion about the emergence of the land claims process following the Calder decision in 1973, the logics are the same: threatened by Indigenous groups asserting their inherent rights as sovereign nations, the settler state then reacts and pivots to inclusionary politics that effectively undermine Indigenous nations' claim to sovereignty by containing the discourse within the purview of the Canadian state, and ultimately, within colonial governmentality.

The TRC emerged shortly after this discursive shift, following the 2008 IRSSA. This largely aspirational conceptualization of reconciliation works to restore "estranged or damaged social and political relationships" (Coulthard, 2014, p. 107). Looking directly to the TRC, its mandate outlines a vision of reconciliation that is able to "put the events of the past behind us so that we can work towards a stronger and healthier future" ("Schedule N," 2008, p. 1). This strictly forward-looking vision operationalizes narratives of truth-telling, renewed relationships, mutual respect, and respect. These ideals are echoed in Volume 6 of the Final Report, which is entitled 'Reconciliation.' Here, the TRC explicitly outlines that reconciliation is not only about "establishing and maintaining a mutually respectful relationship between Aboriginal and nonAboriginal peoples in this country" ("Volume 6," 2015, p. 3), but also requires reconciliation with the natural world: as the report maintains, "reconciliation will never occur unless we are also reconciled with the earth" ("Volume 6," 2015, p. 13). A sharp contrast to the kind of reconciliation that RCAP envisioned, the TRC effectively mainstreamed conversations about Indigenous-settler relations during its 8-year mandate. As a result of its increased prominence in public discourse, the scholarly critiques of reconciliation are broad, diverse, and well-researched across the globe; I outline these in my next section. 
In sum, the term reconciliation is now understood in a plethora of different contexts in Canada for many different actors. These meanings range from healing and relationship-building, court cases and Indigenous rights recognition, to resource development and sovereignty as well as expanding to include policing, incarceration, child welfare, and missing and murdered Indigenous women, girls, and two-spirit folks (Wylie, 2017, p. 602). I organize these conceptualizations into two broad categories: political reconciliation, which was born from constitutional recognition in Section 35, and the more mainstream cultural reconciliation, which emerged largely as a consequence of the TRC Final Report.

Yet, Indigenous perspectives on the meaning of reconciliation highlight the deeply relational and reciprocal imperatives that must operate within the concept. To this end, as Anishinaabe academic Hayden King and Nehiyaw writer Erica Violet Lee (2013) highlight, because Indigenous peoples have diverse political and cultural traditions that vary by nation and region, they also have diverse visions for the future. Just as diverse, therefore, are Indigenous understandings of reconciliation, decolonization, and resurgence (King \& Lee, 2013). Nonetheless, Indigenous academics and activists (Ladner, 2018; Coulthard, 2014; Simpson, 2011; Manuel, 2017; Harp, 2016; George, 2017) see a common thread within these understandings, which inherently ties reconciliation to land. While most of the critical commentary of reconciliation politics definitively rejects the concept, Kiera Ladner (2018) suggests that when the term is operationalized within Indigenous practices, theories, or ethics, "reconciliation, much like governance, is about living the good life [...] or living collectively in accordance within an ecological contextuality, or an ethical relationality" and is thus a process, action, and something "that must be continuously created and maintained" (p. 245). Echoing this, at a talk at Ryerson University in April 2019, Anishinaabe comedian Ryan McMahon suggested 
reconciliation should be conceptualized in accordance with biskaabiyiing, which is Anishinaabemowin for "understanding the past in order to move forward in a good way." This is not to suggest that reconciliation allows the past to be forgotten, but actually promotes the contrary: a profound acknowledgement of first, a shared history that is unequivocally based on white supremacist and heteropatriarchal conquest and genocide, which stems from the violent and illegal theft, occupation, and destruction of Indigenous lands, and second, the ways in which this history is manifested, normalised, and perpetuated today. And as I make clear in my next section, the repatriation of Indigenous land must be at the centre of discussions about reconciliation.

\section{A Review of Critical Literatures in Reconciliation Discourse}

Research on reconciliation can be cast into two broadly-defined understandings, following the same two categories sketched above: legalistic, constitutional approaches, and aspirational conceptualizations. This distinction is consistent with the manner in which I organized my empirical corpus; while news releases related to treaty, land claims settlements, and self-government agreements generally invoke the former conceptualizations of the term (Manuel, 2017; Coulthard, 2014; Ladner, 2017; Wylie, 2017; Turner, 2013; Short, 2008; Clark et al., 2016; Newman 2008), and the latter are mostly tied to IRS and the TRC (Coulthard, 2014; Davis et al., 2017; James, 2017; Turner, 2013; George, 2017; Regan, 2018; Henderson \& Wakeham, 2013; Mackey, 2013). Consequently, as Coulthard (2014) argues, the federal government, and in particular the Department of INAC (as can be seen on its website and in news releases, for example), uses the term in both instances to ideologically frame the violences of settler colonialism firmly in the past in order to leave "the present structure of colonial rule largely unscathed" (p. 22). I argue that while the Department of INAC and its Minister employ 
the concept of reconciliation inconsistently and in a number of different rhetorical ways, Trudeau and his government more broadly have nonetheless been steady in framing reconciliation as a “coherent project $[\ldots]$ to shore up national mythologies of Canada's dedication to pluralism and to reinforce Canada's international reputation as a peacekeeping, peace-making nation" (Henderson \& Wakeham, 2013, p. 7). To this end, the strongest criticisms of reconciliation politics are twofold: without using the language of colonialism, it functions first to historicize ongoing colonial violence in Canada and second, it does not "adequately transform the structure of dispossession that continues to frame Indigenous peoples' relationship with the state" (Coulthard, 2014, p. 120). In response to these critiques, this section will then close with a more general discussion of reconciliation politics and open up the dialogue to explore land-centred possibilities that focus on decolonization through land restitution and Indigenous resurgence (Simpson, 2011, 2017; Coulthard, 2014; Lee, 2016; Tully, 2018; Denis \& Bailey, 2016; Ladner, 2017; McCrossan, 2013, 2015; Dhillon, 2017; George, 2017; Henderson \& Wakeham, 2013).

The critiques of the legalistic interpretation of reconciliation are overwhelmingly centred on the premise that recognition within Section 35 of the Constitution is essentially an extinguishment of Aboriginal title and rights, much like White Paper-era assimilationist policies ${ }^{18}$ aimed at subsuming Indigenous identity into the broader Canadian body politic (Manuel, 2017, p. 202). Note that this critique is familiar within the context of the extinguishment clause in the respective state-led land claims and self-government processes. In a seamless extension of his discussion on the recognition paradigm, moreover, Coulthard (2014)

${ }^{18}$ P.E. Trudeau's 1969 White Paper sought to dismantle the Indian Act and thus extinguish the fiduciary relationship between the Canadian Federal government and Indigenous peoples. Interestingly, Dhillon (2017) also argues that "as a consequence of this paper, the first seeds of multiculturalism were planted in the social imaginary of Canada" (p. 60). 
speaks specifically to this idea and articulates that the goal of reconciling Indigenous nationhood with state sovereignty through constitutional recognition is still fundamentally colonial "as it remains structurally committed to the dispossession of Indigenous peoples of their land and selfdetermining authority" (p. 151). To this end, the concept of reconciliation in the context of Section 35 is essentially problematic for two, interrelated reasons: it is not fundamentally centred on the repatriation of stolen Indigenous land, while being inherently based on the legitimacy of the Canadian Constitution. Legally, Section 35 serves to rigorously outline, interpret-- and reinterpret via court decisions-- Indigenous peoples' inherent rights while maintaining status quo Canadian sovereignty (Henderson \& Wakeham, 2013, p. 111). There is, as Damien Short (2008) argues, a 'colonial ceiling' on Indigenous self-determination that is tightly controlled and managed through political boundaries of acceptability (p. 162). This form of reconciliation discourse is found typically in land claims and self-government contexts, thus, does not at all shift the asymmetrical power imbalance between the Canadian state and Indigenous nations. This will also be expanded upon at length in Theme 2 of my analysis that follows (pp. 80-86). As such, while the politics in this context give the appearance of change and progress, constitutional recognition and reconciliation actually secure, perpetuate, and further legitimize the settler colonial status quo "while simultaneously heading off alternatives geared toward a more fundamental transformation of constitutional relationships" (Wylie, 2017, p. 625). What is more, Ladner (2017) argues that the state's vision, as articulated through court rulings and policy decisions for example, negates any type of meaningful reconciliation because it is neither mutually agreeable, nor mutually beneficial for Indigenous nations (p. 247). Unlike resurgence, which centres the reconnection of Indigenous peoples with land and community, reconciliation focuses on state-led processes of governmentality that are based on continued theft of land, white 
supremacy, capitalism, extractivism, heteropatriarchy, and ableism.

Much like the way that reconciliation discourse is operationalized in the context of land claims settlements and self-government agreements, it works to maintain the settler colonial status quo in the context of IRS and the TRC, albeit through different means. For example, reconciliation in these particular instances discursively situates conversations of colonialism firmly and definitively in the past. This fabricates a distinct schism between Canada's colonial past and our assumed-postcolonial present (Blackburn, 2007), which not only validates the ongoing dispossession and displacement of Indigenous peoples from their lands, but also obscures the fundamentally violent colonial relationship between the state and Indigenous peoples that continues today. To this end, this temporal containment of colonialism in Canada allows the state to compartmentalize its violence against Indigenous peoples to one particular set of genocidal policies-- the state-sanctioned IRS system-- rather than addressing how these policies permeate the entire constitutionality of Canada and thus are very much ongoing projects (Coulthard, 2014); as Nuu-chah-nulth scholar Rachel George (2017) articulates, "struggles for stolen land are ongoing, Indigenous children continue to be found in state care at disproportionate rates, colonial violence continues and can be seen at high numbers of missing and murdered Indigenous women and girls" (p. 55), to name only a few manifestations of contemporary colonial violence in Canada.

Furthermore, the tendency for the federal government, and Canadian society more broadly, to equate reconciliation with forgiveness and healing becomes problematic as it places the onus on "Indigenous subjects [as] the primary object of repair, not the colonial relationship" (Coulthard, 2014, p. 127). Consequently, the goal of reconciliation here focuses on fixing those harmed by IRS (Million, 2013) rather than addressing "the continued Canadian sources of that 
harm, such as land dispossession, structural poverty, and overincarceration" (James, 2017, p. 379). Furthermore, many scholars echo this critique (Coulthard, 2014; Davis et al., 2017; Mackey, 2013; George, 2017; Simpson, 2011); without critically ‘learning and unlearning’ settler colonial hegemonic norms (Davis et al., 2017), reconciliation efforts like those promoted via the TRC to not only assuage any settler state responsibility (George, 2017) by failing to implicate settlers as beneficiaries of violent colonial policies (Mackey, 2013, p. 54), but also effectively subdue substantive change in decolonial or resurgent contexts by "delinking [colonialism] from material processes and placing it in the past" (Mackey, 2013, p. 54). In an apt summary, Coulthard (2014) theorizes that the state deliberately constructs the concept of reconciliation in order to attribute "the abuses of settler colonization to the dustbin of history, and/or to purposely disentangle processes of reconciliation from questions of settler coloniality" (p. 108).

It follows, then, that meaningful reconciliation must work to address historical and ongoing manifestations of settler colonial violence by recognizing Indigenous nations' inherent right to self-determination, returning substantial swathes of stolen land, and honouring treaty relationships (Coulthard, 2014, p. 127); as Manuel (2017) maintains, without these overarching objectives, reconciliation is effectively "meaningless and allows settlers to "have the cake and eat it too': not only do settlers "get to keep the stolen land, [they] are forgiven for the theft" (p. 201). As outlined extensively above, land restitution is fundamentally missing from government discussions of reconciliation. James Tully (2018) picks up on this imperative and argues "as long as our unsustainable relationship to the living earth is not challenged, it will constantly undermine and subvert even the most well-meaning [...] efforts to reconcile the unsustainable relationship between Indigenous peoples and settlers through modern treaties and consultations" 
(p. 84). Accordingly, then, at the most basic level, whether its related to constitutional recognition or the TRC, reconciliation politics must account for and speak to not only historical and ongoing state violences against Indigenous peoples, but also the ways in which the continued occupation of the settler state on stolen Indigenous lands is intricately tied to white supremacy, capitalism, and extractivism.

With the above review of literature in mind, it is clear that reconciliation politics has been widely researched and extensively discussed. The idea that reconciliation fails to subvert the ever-shifting logics of colonial hierarchy is well-documented in many different contexts across the globe. However, there still remains an important gap in knowledge as it relates to INAC, the Canadian federal department charged fulfilling the Crown's fiduciary responsibility to Indigenous peoples. As this careful review of literature highlights, while many scholars have critiqued reconciliation politics in the context of constitutional recognition and the TRC, for example, I have not encountered any studies specifically dedicated to INAC that pick up on this discussion. With a goal of further understanding and contextualizing the political legitimation of settler colonial governmentality in Canada, my research project seeks to bridge this aforementioned gap in knowledge by critically interrogating how the government operationalizes reconciliation discourse in public news releases issued by INAC. As we will see, INAC uses the concept of reconciliation in the context of news releases that focus on land claims settlements and self-government agreements as a deliberately ambiguous discursive tool of quiet, polite, and characteristically Canadian assimilation. My project works to extend the above discussions of reconciliation discourse in the context of the federal land claims settlements frameworks and the state-led self-government process. These insights then support my findings: although the logics of the Canadian government's approach to Indigenous-settler relations appear to be shifting, 
reconciliation nonetheless fundamentally serves to simultaneously erase any Indigenous claim to land (as inherent) that exists outside of the colonial purview; to facilitate assimilation via the absorption of Indigenous identity into Canadian body politic; to validate colonial supremacy; and to ensure settler futurity in Canada. 


\section{Chapter 5: Land Claims Settlements and Self-government Agreements as Frameworks of Occupation}

To translate this critique of policy into a methodical analysis, I adopted a multi-method critical review of reconciliation discourse in federal government policy. My approach includes both a review of federal policy and a discourse analysis of public-facing INAC news releases. In particular, I focus on the sociohistorical context of both the federal land claims and selfgovernment policy frameworks to frame my policy review, and conducted a critical discourse analysis of 39 INAC news releases that specifically discuss these frameworks (Fairclough, 1995). Rather than list them in my bibliography, my sample of 39 news releases are listed in Appendix II thematically in reverse-chronological order, each referred to as Items 1 to 39 when quoted for analysis. As documents of political communications speaking to three distinct policy frameworks (those are: the Comprehensive Land Claims Process, Specific Claims Process, and self-government), these INAC news releases play a unique and central role in public knowledge about government's continued control and regulation of Indigenous access to land and community. Moreover, these policies referenced and reflected in the news releases represent the federal government's vision for reconciliation in a real and tangible way. Like the concept of reconciliation, federal land claims policy and self-government agreement frameworks have been criticized as being duplicitous (Samson, 2016). While the rhetoric surrounding the policies may seem beneficial to Indigenous communities, the limitations and stipulations (discussed directly below) embedded in these policies reveal the federal government's true motivations: a concerted effort to maintain control and regulation of all lands within the borders of the Canadian state.

At a basic level, the settlement of land claims is broken up into two processes led by the

federal government. While the Specific Claims Process (SCP) is the federal government's way of resolving issues related to land claims within the boundaries of the historic and Numbered 
Treaties, the purpose of the Comprehensive Land Claims Process (CLCP) is to settle lands that were not included in the historical treaty process. It is also worth mentioning the Additions to Reserve Policy ${ }^{19}$ and the First Nations Land Management Act (FNLMA) ${ }^{20}$ as other, related policy frameworks that reside outside of the scope of my project. In a different, yet related set of federal policies, moreover, self-government agreements are the second major framework that my analysis interrogates in the context of reconciliation discourse. Although this process works entirely outside of land claims settlements, the two frameworks often work in tandem, and land claims agreements often include a self-government chapter (Alcantara \& Davidson, 2015, p. $554)$.

As frameworks of occupation, land claims settlements and self-government agreements work to establish jurisdiction, which "has been enacted by the state as a form of power to usurp the inherent laws of Indigenous peoples and replace their authority with the delegated authority of federal and provincial governments" (Pasternak, 2017, p. 22). Since the creation of the Canadian state did not eliminate Indigenous governance structures, Indigenous claims to political authority "reveal the unfinished project of perfecting settler sovereignty claims" (Pasternak, 2017, p. 147); and as Torres Strait Islander scholar Sana Nakata articulates, "Indigenous sovereignty exists whether or not land claims settlements and self-government agreements exist"

${ }^{19}$ The Additions to Reserve process is the framework that leads to the creation of new reserves and the increase of land base for First Nations. For a brief summary of this policy, Iwama, D. (2018, August 14). On the road to the new reserve: Considering Canada's preferred path to land restitution. Yellowhead Institute, 9, retrieved from https://yellowheadinstitute.org/wpcontent/uploads/2018/08/additions-to-reserve-brief-1.pdf.

${ }^{20}$ FNLMA agreements that flow from this process give First Nations the opportunity to opt out of land and resource provisions in the Indian Act. Functioning essentially as land codes to assume self-government over land, the FNLMA is another significant aspect of federal policy that regulates the way Indigenous peoples access and interact with their lands. For an informed critique of the FNLMA, please refer to Jung, C. (2019). The First Nations Land Management Act: Twenty years of reconciliation, American Review of Canadian Studies, 49(2), p. 247-61. 
(personal communication, September 11, 2019). This highlights how important it is for the government to enter into these processes with Indigenous groups because it formalizes the subordination of Indigenous governance structures (sovereignty) and finalizes the Crown's ownership (sovereign claim) of otherwise unceded territories.

With this in mind, the following sections delineate the sociohistorical context of the two federal land claims processes and self-government agreement frameworks, respectively. This policy review will set the foundation for the next section, where I take a closer look at some of the more nuanced issues associated with the federal frameworks. Critical scholarship is woven into the discussion to elucidate the limitations of these state-led processes in enshrining sovereignty and decolonization. My discussion is informed by a number of influential scholars in the field (Pasternak, 2017; Diabo \& Pasternak, 2014; Diabo, 2013; Alcantara, 2008, 2013, 2017; Samson, 2016; Dickson, 2015; Lawrence, 2012), who have written important and thoughtful critiques of federal land claims policies. To complement this work, I look to different insights in the field that relate specifically to self-government agreements (Irlbacher-Fox, 2009; Alcantara \& Davidson, 2015; Alcantara, 2013; Slowey, 2001; Salee \& Levesque, 201). Broadly, these critiques inform the organization of my three analytical themes, which thus problematize the concepts of certainty, absolute Crown authority, and history in the context of reconciliation discourse in political communications. Specifically, I examine the role of certainty in extinguishing Indigenous peoples' inherent rights; the fundamentally asymmetrical power dynamic at the negotiating table; and the frameworks' role in historicizing colonialism by situating injustices in the past.

I then draw on my CDA to illustrate these critiques in practice; I use these three critiques to frame a discussion of micro-, meso-, and macro-levels of discourse (Fairclough, 1995) in my 
corpus as I seek to draw connections between the respective policies and the positive portrayal of the settlement process through the discursive ambiguity associated with reconciliation. My analysis tangibly demonstrates the subtle ways that the logics of settler colonialism are upheld as common sense through both policy and practice. Broadly, this critical analysis works to meaningfully interrogate how, as tools of assimilation, these federal processes function within reconciliation discourse to reproduce modes of colonial governance and uphold settler occupation. To this end, Dhillon (2017) articulates, "participation is a form of colonial statecraft camouflaged by a discursive landscape of recognition and reconciliation" (p. 22). For the purposes of my analysis, I work to draw strong connections between these respective policy frameworks, the settler colonial logics that underpin the Department of INAC, and reconciliation discourse. My analysis also considers a broader discussion of settler governmentality by highlighting on the intimate connection between reconciliation discourse and capitalism in perpetuating modes of colonial governance. Functioning as a review of these policies, the expanded critiques will draw on illustrations from INAC news releases as a means of elucidating the intertextual nature of ambiguity in the context of reconciliation discourse.

My analysis showcases how reconciliation is used in many different contexts to signify different ideas. I argue that this discursive ambiguity is a deliberate move by INAC, and the federal government more broadly, to manipulate the way that Indigenous peoples interact with the land and their communities. Reconciliation, as an ambiguous political term, works through tools of assimilation like land claims settlements and self-government agreements to erase any Indigenous claim to land (as inherent) that exists outside of the colonial purview, to facilitate assimilation via the absorption of Indigenous identity into Canadian body politic, to validate colonial supremacy, and ultimately to ensure settler futurity in Canada. This is consistent with 
Mohawk anthropologist Audra Simpson's (2016) crucial assertion that Canada is a settler society "whose multicultural, liberal, and democratic structure and performance of governance seeks an ongoing 'settling' of this land" (p. 1). Reconciliation, I argue, is central to the ongoing project of settler colonialism. Ambiguity, moreover, is central to the continued, widespread, and uncritical acceptance of aspirational reconciliation discourse in the Canadian public sphere.

\section{A Brief Policy Review}

Looking at the first of two federal land claims frameworks in my analysis, the Comprehensive Land Claims Process (CLCP) emerged initially in 1973 after the Supreme Court of Canada (SCC) split decision ${ }^{21}$ in Calder et al. v. Attorney-General of British Columbia. This ruling recognized the existence of Aboriginal title to land, which is essentially understood as "a bundle of common law rights of use and enjoyment of ancestral land that stemmed not from any positive legal enactment but from Aboriginal 'possession from time immemorial"' (Macklem, 2001, 268-69). In other words, the decision sought to resolve whether or not the Nisga'a Nation "held underlying title to the land or whether the province was right in claiming that their title was extinguished with the creation of British Columbia in 1871" (Pasternak, 2017, p. 29). In naming this underlying title to land as 'Aboriginal title,' the Calder decision stipulated that "unceded lands and rights required specific legislation or agreements to extinguish them" (Samson, 2016, p. 88). The SCC decision was the culmination of decades of effort by the Nisga'a Nation and had far-reaching implications, opening up the possibility for other Indigenous groups to claim underlying Aboriginal title to their land in unceded territories (Pasternak, 2017, p. 141). This profoundly juxtaposed settler and Indigenous legal orders and had the possibility to

${ }^{21}$ Three in favor of the plaintiffs, three against, one dismissal based on a technicality. 
fundamentally unsettle colonial jurisdiction (Pasternak, 2017, p. 246). The CLCP was consequently created in order to mitigate the potentially far-reaching effects of the undefined rights encompassed within Aboriginal title; as Coulthard (2014) highlights, the state responded to the uncertainty of these undefined Aboriginal rights following Calder by "structurally circumscribing the terms and content of the recognition it was willing to make available $[\ldots]$ through the negotiation of a land settlement" (p. 66). The new federal land claims policy essentially exchanged "claims to undefined Aboriginal [and treaty] rights for a clearly defined package of rights and benefits set out in a settlement agreement" (DIAND, 2000, p. 1). In practical terms, since the Calder decision created legal uncertainty in unceded areas of the country, the CLCP sought to resolve this ambiguity through the inclusion of an extinguishment clause in all settlements in order to maintain control over how Indigenous peoples exercise jurisdiction over their lands, particularly in unceded territories ${ }^{22}$. Accordingly, the notion of certainty and the extinguishment clause is the first of the three expanded critiques below.

Since 1973, the CLCP has been revised only a number of times. While the 1997 SCC decision Delgamuukw v. British Columbia affirmed that Aboriginal title could not be extinguished without consultation, Tsilhqot'in v. British Columbia in 2014 went even further by stating that "extinguishment actually required consent" (Samson, 2016, p. 88). The ruling was

\footnotetext{
${ }^{22} \mathrm{NB}$ : Whereas the first iteration of the CLCP bluntly demanded the actual extinguishment of rights and title, subsequent revisions to the policy move away from referencing actual 'extinguishment' and instead use the language of 'exchanging' Aboriginal title for treaty rights as defined in the agreements. Essentially, this exchange of rights was once accomplished through the language of 'extinguishment' which, in light of Delgamuukw, gradually changed into the 'modified rights' approach. Yet, many critics agree that the 'modified rights,' which still extinguishes title in exchange for fee simple property, is a "key step in the termination of collective Indigenous lands as well as in perfecting settler sovereignty [because] fee simple subordinates Indigenous land under provincial jurisdiction, terminating its distinct legal order" (Pasternak, 2017, p. 247-8).
} 
careful to make the distinction that Aboriginal title consisted of the right to use (and sometimes govern) the land, without actually owning it (Samson, 2016, p. 88). This stipulation further underlines the lengths that the government will go in order to maintain ultimate control over land, which is especially important in the particular context of British Columbia, where the lands are often unceded and extremely lucrative for extractive industries. To this end, the government has not hidden the ways in which its capitalist agenda is intertwined with the CLCP. Accordingly, after the 2014 SCC decision, the federal government released an interim paper on the CLCP, which "repeatedly attributes a strong connection between land claims and economic growth" (Samson, 2016, p. 88). Importantly for my project, moreover, this 2014 paper marked a significant shift by the government to include land claims within "the wider project of 'recognition' or 'reconciliation,' evolving from the liberal democratic framework of rights" (Samson, 2016, p. 88). This shift is consistent with Section 35(1) Aboriginal and treaty rights that are enshrined in the Constitution Act, 1982, which are purposively aimed at promoting reconciliation; as scholar Shiri Pasternak (2017) articulates, reconciliation is indeed best expressed "through the land claims and other non-treaty agreements that manage conflict over land by replacing Indigenous jurisdiction with the 'certainty' of Crown ownership" (p. 146). The connection between the capitalist motivations behind the land claims process and the inclusion of this process within reconciliation discourse is a reflection of the logics of settler governmentality at the core of the land claims process more broadly. As one Harper-era news release outlines:

Land claims settlements create investment and business opportunities that can bring economic benefits and build new partnerships for First Nations and neighbouring communities. Settling land claims is key to achieving reconciliation and rebuilding relationships with First Nation Communities in Canada. (Item 16)

The connections between land claims processes, reconciliation, and capitalist development continued into Trudeau's Liberal Party narrative strategy, moreover, as can be seen in two news 
releases which describe "the settlement of land claims [as] key to advancing reconciliation with Indigenous communities in Canada and creates the foundation for social development and economic growth that can generate benefits for Indigenous peoples and all Canadians" (Items 1, 2). The problematization of the political messaging in INAC news releases allows for a more nuanced look into the inner workings of capitalist logics in land claims policy. The ambiguous nature of reconciliation in the above examples, for instance, highlights how the positive spin of the 'benefits' of settling claims works within hegemonic capitalist ideology to obscure the negative consequences to settlement, such as extinguishment of Aboriginal title, for example.

I will now turn to the second major federal land claims framework, the Specific Claims Process (SCP). In the post-Calder era, specific claims were settled at an ad hoc basis until the federal government released its first formal federal policy on specific claims in 1982, entitled Outstanding Business (Dickson, 2018, p. 36). As Jane Dickson (2018) articulates, "claims exist because promises were not kept" (p. 13) and accordingly, the SCP seeks to remedy the "nonfulfillment of a treaty or agreement between the Crown and Indigenous people; breaches of obligations under the Indian Act, treaties, and surrenders; and breaches arising from government administration of Indigenous monies and assets or from the illegal dispossession of Indian land" (p. 37). Moreover, the SCP not only deals with land grievances on historic treaty lands, but can involve other kinds of 'specific' claims as well. In the context of the historic treaties, for example, a specific claim "could involve the failure to provide enough reserve land as promised in a treaty or the improper handling of First Nation money by the federal government in the past" (Crown-Indigenous Relations and Northern Affairs Canada, 2015). Notably, extinguishment of Aboriginal rights and title is also a linchpin to the SCP (Dickson, 2018, p. 43). This policy was so riddled with problems in its initial implementation that it is even considered a direct instigator 
for the standoff at Oka in $1990^{23}$. In response to the violence at Oka, the federal government consequently established the Indian Specific Claims Commission (ICC) in 1991 as an independent review body to oversee the claims process at an arm's length from government (Dickson, 2018, p. 5-6). In 2007, the Harper government introduced the Justice at Last policy, which aimed at addressing the backlog of claims, but has been criticized for justifying "either hasty rejection of claims or acceptance with an offer of resolution that is [unfair to claimants]" (Dickson, 2018, p. 7). It is also important to note that the Harper government decommissioned the ICC in 2009 despite its widespread success in conducting inquiries into ninety-six claims, producing sixteen annual reports, and publishing twenty-six studies in its 18-year lifespan (Dickson, 2018, p. 6). Perhaps as a consequence of shutting down the ICC, Dickson (2018) maintains that while "expert opinion suggests that roughly 70 percent of submitted claims are valid, the actual rate of validation under Justice at Last, after an initial flurry of offers, is 20 percent or less" (p. 7). Interestingly, a news release from 2012 frames settlement negotiations with the Harper government as being "committed to resolving this claim fairly, expeditiously and in the context of respect and good will that characterizes their mutual dealings" (Item 13). Evidently, the reconciliatory discourse of 'respect' in this news release sharply contrasts the critical literature and highlights a much larger issue associated with the land claims process, which is the inherently asymmetrical balance of power at the negotiating table, which is a critique I return to in the second subsection below (pp. 80-86).

${ }^{23}$ The Oka Crisis was a 78-day standoff in Oka, Quebec between Mohawk land defenders, police, and the army. The conflict arose due to a proposed expansion of a golf course and development of condominiums on disputed land that included a Mohawk burial ground" (Marshall, 2019). This proposed development came after the Mohawks of Kahnesatake's specific claim to their sacred lands had been denied by the Department of Indian Affairs, opening up the possibility for development (Dickson, 2018, p. 5). Thus, the conflict can be tied directly to the failed of a specific claim. 
Like the CLCP, the push for self-government agreements also emerged in the 1970s as a result of the Calder decision, which compelled the federal government to establish the first formal self-government negotiation frameworks (Slowey, 2000, p. 8). While the Calder ruling rejected the Nisga'a's claim that their Aboriginal title was unextinguished, Justice Judson, who wrote for three of the seven justices, notably recognized that "Indians were there, organized in societies, occupying the land as their forefathers had for centuries" (Calder et al. v. AttorneyGeneral of British Columbia, 1973, p. 328). This articulation not only made the Nisga'a Nation's claim to land legible in common law by recognizing the claim as based on a proprietary right, but also affirmed the notion that the Nisga'a were self-governing prior to settler occupation (Belanger, 2008, p. 43). But the discussion around the right to self-government was not picked up again until the Parliamentary Task Force on Indian Self-Government was established in late 1982 to define the parameters of Aboriginal self-government. It concluded, among other things, that self-government represented a "distinct order of government" that would be responsible for a particular set of negotiated jurisdictions like child welfare, health care, and education for example (Belanger, 2008, p. 9). As such, the Cree-Naskapi Act was implemented in 1984 and is considered the first self-government model; in exchange for "ceding vast tracts of territory and voluntarily extinguishing their Aboriginal title" (Belanger, 2008, p. 11), the Cree and Naskapi were formally recognized as having title to and control over negotiated aspects of selfgovernment. Then, in 1986, the federal government changed its policy on negotiating selfgovernment by introducing the Federal Policy on Community-Based Self-Government Negotiations (Alcantara \& Davidson, 2015, p. 562), which sought to open up the possibility of negotiations for "new Crown-Aboriginal relationships outside of the Indian Act" (INAC, 2011). 
Moreover, the $1990 R v$. Sparrow decision pushed the boundaries for self-government further by prioritizing Indigenous rights over "restrictive federal legislation" (Slowey, 2000, p. 8). Seeking to remedy the failings of the previous policies, the federal government introduced the 1995 Inherent Right Policy, which clearly affirmed that Indigenous peoples not only have an inherent right to self-government, but this right is also protected under Section 35(1) of the Constitution (Alcantara \& Davidson, 2015, p. 569). A year later, while RCAP called for Aboriginal governments to be recognized as a "third order of government" (Alcantara \& Davidson, 2015, p. 554), the $R v$. Van der Preet decision "reversed the progress that had been made in recognizing Aboriginal title" by tightly containing Aboriginal rights within the purview of the Canadian Constitution (Slowey, 2000, p. 9). Basically, this decision concluded that Aboriginal rights are not derived from Indigenous peoples' occupation of the land since time immemorial, thus undermining the concept of underlying title (Slowey, 2000, p. 9). The current federal self-government process is firmly situated within the existing constitutional and legal orders of Canada and functions to outline the range and scope of certain areas of jurisdiction (Alcantara \& Davidson, 2015, p. 554).

Yet, what exactly do these settlement agreements amount to? Practically, final agreements are constitutionally-protected by Section 35 of the Constitution Act, 1982 and tripartite between an Indigenous community (or Indigenous communities), the federal government, and the relevant provincial/territorial government. The CLCP begins when an Indigenous group submits a statement of intent that proves the following three claims: that their right to the claimed lands has not been previously extinguished; that they historically occupied and used the claimed lands to the exclusion of other groups; and finally that they are an 
identifiable and recognizable Indigenous group ${ }^{24}$ (RCAP, 536-537). The SCP is similar to this and involves three steps. First, the Crown reviews the First Nation's claim to confirm it meets the 'minimum standard for claims submissions,' which is essentially a historical record of the claim that must be agreed to by the federal government before continuing (Dickson, 2018, p. 84). Once accepted, the Department of Justice conducts a legal review of the claim, which is then submitted to the Specific Claims Tribunal to inform either the acceptance or rejection of the specific claim (Dickson, 2018, p. 84). A settlement under both of these processes could include both the transfer of land and compensation via cash, and CLCP could also include the potential transfer of jurisdiction over natural resources, fish and wildlife, migratory birds, taxation, economic development, water management, among other jurisdictional areas (Alcantara, 2013, p. 3).

Similar to the land claims process, self-government negotiations begin when Indigenous groups submit a proposal that is then either accepted or rejected by the Crown. The consequent negotiations consist of developing a detailed, tripartite framework agreement with the federal government and provincial/territorial government that outlines "the structure and accountability of Aboriginal governments, their law-making powers, financial arrangements and their responsibilities for providing programs and services to their members" (AANDC, 2012). These responsibilities generally include some form of limited jurisdiction, which David Bedford (2010) refers to a 'piecemeal' transference of power "from the Crown represented by the Minister of

\footnotetext{
${ }^{24}$ These provisions are problematic for a number of reasons. For one, based in colonial conceptions of space and territory, this rigid claims process cannot account for the ways that land was shared by Indigenous nations prior to occupation. Overlapping claims to territory proves to be a major hindrance in the British Columbia Treaty process, for example, as these singular claims to land cannot encompass a relationship with land that is not centred upon neoliberal and individual capital accumulation. Second, the claims processes is only available to groups that, for the most part, are federally-recognized, thus validating the federal government's ability to effectively regulate Indigenous identity.
} 
Indian Affairs, to the chief and council, the governing entity established by the Indian Act" (p. 207). Some of the policy areas included in these agreements are: "membership rules for the community; marriage, adoption and child services; language and culture; health and social services; the administration and enforcement of justice; property rights and land management; taxation, housing, hunting and agriculture, natural resource management, public works" (Alcantara, 2013, p. 15).

\section{Theme 1: Certainty and Extinguishment as Central Tenets of Agreements}

As can be seen, the Calder decision is crucial in understanding the inception of both land claims and self-government policies at the federal level. To recall, while Calder did indeed recognize the existence of Aboriginal rights and title to land, the government's response to this legal uncertainty was to craft policies that sought to settle land claims and define Aboriginal rights once and for all. In practical terms, this means that all settlements emanating from the both the CLCP and the SCP include an extinguishment clause, which terminates this recognized Aboriginal title in exchange for a level of 'certainty' of jurisdiction that is ultimately regulated and controlled by the federal government. Importantly, self-government frameworks also require that Indigenous groups waive their inherent right to self-government as protected by Section 35 of the Constitution through the mandatory inclusion of an extinguishment clause (Irlbacher-Fox, 2009, p. 7). Dara Culhane (1998) aptly theorizes that "at precisely the same moment that the Crown recognizes title, Aboriginal peoples must surrender it" (p. 347). This problematic and highly criticized exchange of rights can thus be understood as a centerpiece for federal land and governance policy (Dickson, 2018). The extinguishment provision has been widely criticized, perhaps most vocally by Kahnawake policy analyst Russel Diabo (2013) in the context of land claims, who describes the CLCP specifically as a 'termination plan.' 
For Indigenous groups that are engaged in this process, moreover, this notion of certainty is also promoted as a means of ensuring that the specific rights outlined in the settlement are recognized. Yet, as Corntassel (2008) maintains, the existing rights discourse can take Indigenous peoples only so far (p. 105) as it is still contained within colonial institutions. In particular, by centring 'certainty' as its overarching objective, Alcantara (2013) maintains that the land claims process serves to validate the Crown's assumed authority "by insisting on the cession of Aboriginal title and rights that may have previously made the state's assertion ambiguous" (p. 103). In this way, understanding land claims settlements and self-government agreements as tools of assimilation highlights the profoundly asymmetrical balance of power perpetuated in these respective negotiations; the Crown has the power to 'give' rights and jurisdiction to Indigenous groups, thus further normalizing the "dominant-subordinate relationship [as] the natural order of things" (Irlbacher-Fox, 2009, p. 160). This observation is crucial, especially when considering the government's consistent framing of the negotiations as 'nation-to-nation' and in the spirit of reconciliation. The reality is, the government not only writes the negotiation process, but also chooses when and when not to engage with Indigenous nations at all. I will discuss this issue further in the next subsection.

As non-negotiable provisions in land claims settlements, the extinguishment clause forces Indigenous groups to cede inherent and "pre-existing sovereign status" in exchange for a certain and definable set of rights that are legible ${ }^{25}$ in the colonial legal system (Diabo, 2013); for example, as Paul Nadasdy (2002) points out, Indigenous groups must "translate their complex reciprocal relationship with the land into the equally complex but very different language of

\footnotetext{
${ }^{25}$ For a discussion on claimant legibility, see Scholtz, C. (2010). Land claim negotiations and Indigenous claimant legibility in Canada and New Zealand, Political Science, 62(1), 37-61.
} 
'property"' (p. 248). One news release in particular highlights this micro-level lexical focus on certainty. In the context of the SCP, this example outlines, "negotiated settlements help rebuild relationships and generate benefits for all Canadians. These benefits include economic benefits, new opportunities for business partnerships and certainty for First Nations, industry and area communities" (Item 9). At first glance, this news release connects the settlement process with reconciliation through the notion of 'rebuilding relationships.' This is akin to the cultural public discourse that largely emanated from the TRC. Framing the legal reconciliation of Aboriginal title with Canadian sovereignty through the notion of 'certainty' in the settlement of land claims is highly problematic as it obscures the very real ways that this reconciliation extinguishes Aboriginal rights and title as protected by Section 35 of the Constitution. What is more, the tangible application of 'reconciliation' in the legal sense is muddled with aspirational, relationship-building rhetoric. I argue that this is a deliberate move to create ambiguity surrounding the meaning of reconciliation.

To the majority of the Canadian public, reconciliation does not relate to the legal implications of Section 35, but instead TRC-inspired themes of equality and forgiveness (Environics, 2016, p. 33). The ambiguity thus benefits INAC, and the government more broadly, because it allows reconciliation in this news release to function rhetorically as a substantive solution or 'benefit,' while it actually practically facilitates the extinguishment of Aboriginal title. This reality, though, is hidden behind reconciliatory discourses of relationship-building. As Dhillon (2017) articulates, "the unfinished business of settler societies involves a perpetual negotiation of settler jurisdiction over Indigenous peoples in terms of territory, law, culture, and identity. Moreover, these negotiations and their outcomes continue, as they always have, to produce material realities-- this is not a rhetorical exercise" (p. 9). I argue that the material reality 
is indeed the continued common-sense settler occupation of Indigenous territories because it undermines Indigenous nations' sovereign claim to land.

This is the case, moreover, due to the intricate connection between land, capitalism, and reconciliation. Pasternak (2017), for one, discusses the connection between certainty and economic development. As she articulates, "from a business perspective, [land claims settlements] are favored because they remove undefined rights of Aboriginal title and replace them with a stable and transparent property registry system" (Pasternak, 2017, p. 247). Ultimately, this facilitates "the legal conditions necessary for the 'development' of [Indigenous] lands" (Samson, 2016, p. 99). Framed as a key benefit of both land claims settlements and selfgovernment agreements, certainty effectively obscures the overtly assimilatory objectives of extinguishing Aboriginal rights and title through the notion of development and thus implicitly, progress. In a particularly apt example, one news release articulates:

The settlement of land claims and the conclusion of self-government agreements is key to advancing reconciliation with Indigenous communities in Canada. Agreements like this one help create the foundation for social development and economic growth that can generate benefits for Indigenous people an all Canadians. (Item 25)

In this instance, logics of hegemonic settler governmentality are plainly asserted through reconciliation discourse. Notably, Crosby and Monaghan (2012) theorize that settler governmentality reflects "the particular rationalities of governance that animate Canada's relationship with, and governance of, Indigenous peoples" (p. 422). By explicitly linking the settlement of land claims settlements and the conclusion of self-government agreements to social development and economic growth, this example is an articulation of settler common sense and an instantiation of how the colonial politics of recognition works within these policies through reconciliation discourse to obscure the multifarious ways that capitalism/extractivism or 'economic growth' destroys land and consequently, life. What is more, the connection between 
the conclusion of land claims settlements and self-government agreements and reconciliation is particularly interesting in this example because it operationalizes reconciliation simultaneously in both the legal and cultural senses. Writ large, the conclusion of land claims settlements and of self-government agreements $i s$ the reconciliation of Aboriginal rights and title with Canadian sovereignty. Yet, as I have discussed, this is not what the majority of Canadians would notice in this news release. Rather, it is the relationship-mending discourse of 'advancing reconciliation with Indigenous communities' that most Canadians are interested in promoting. Many scholars in my Literature Review argue that reconciliation is problematic because it does not address the theft of land. I extend this line of thinking and argue that the uniquely ambiguous nature of reconciliation is particularly dangerous to decolonizing projects because it effectively legitimizes destructive extractivism under the guise of economic development, which indeed relies on continued settler occupation.

It is important to note, moreover, that despite the mandatory inclusion of the extinguishment clause in all settlement agreements, the exchange of Aboriginal rights and title for a certain set of determined rights in federal land claims and self-government processes is contrary to both Section 35(1) of the Constitution and to a number of SCC decisions that define these rights (Pasternak, 2017). For one, extinguishment is contrary to the outcome of $R v$. Sparrow, which I outlined above it the context of self-government agreements. This decision assessed the scope of these Section 35 rights, requiring that Canada exercise "as little infringement as possible" to these rights in its fiduciary duties to Indigenous peoples (Pasternak, 2017, p. 144). Yet in contrast, Pasternak (2017) describes the CLCP process in practice as "the ultimate and most extreme abrogation of Indigenous jurisdiction" in the state's attempt to perfect its unilateral claim to sovereign rule over unceded and 'uncertain' Indigenous territories (p. 269). 
What does it say about the federal government's intentions when its major policies related to reconciliation actually go against significant case law precedent and the Constitution itself? This is an important note to make, especially considering how INAC news releases consistently portray negotiations in terms of the government's good will and benevolence while fundamentally upholding colonial dominant/subordinate power dynamics.

\section{Theme 2: Agreements as Manifestations of Absolute Crown Authority}

Building on the above discussion, the micro-level discursive notions of certainty and the extinguishment clause are indicative of a larger, meso-level procedural issue in the respective frameworks more broadly. As Dickson (2018) articulates, "vague terminology, narrow conceptions of rights and obligations, [and] delay and disingenuous government practices" (p. 43) are other fundamental issues to the specific claims process, for example. These particular issues highlight not only the theme of agency within the meso-level negotiations process, but also a larger issue, in that the entire process relies on the legitimacy of the Canadian state's claim to sovereignty. As described in the Policy Review above, the first step of the CLCP, for example, is for Indigenous groups to file a statement of intent with the federal and relevant provincial/territorial government, which will either be accepted or refused by those governments. Broadly, the Crown's ability to assume this rights-granting authority is legitimized by the Canadian Constitution. This claim to power is both persuasive and problematic; the country's founding document is widely understood as the Crown's common sense claim to power, yet these truth claims are problematic because they are based on the legal fiction that the lands now known as Canada were vacant when the settlers arrived.

Hardly a reconciled, 'nation-to-nation' negotiation, it is therefore entirely up to federal/provincial governments whether or not to even engage in negotiations, highlighting the 
absolute and overarching power of the settler state in these processes. Both the land claims and self-government processes require that Indigenous groups successfully convince federal and provincial/territorial governments that completing the settlements is in their best interests because completing a settlement is ultimately up to the benevolence of the government, and not the efforts of the Indigenous groups. At a meso/process level, while self-government agreements essentially exemplify the extent to which the federal government is willing to recognize Indigenous peoples' authority and autonomy (Irlbacher-Fox, 2009; Alcantara \& Davidson, 2015), it is clear that this is not an all-encompassing, absolute type of sovereign authority but rather a deliberate and calculated concession of certain aspects of jurisdictional control. And while both the land claims and self-government processes are framed as a positive exchange of rights, critics of the CLCP (for example) understand the policy as simply "forcing Indigenous peoples to surrender jurisdiction of their lands" (Pasternak, 2017, p. 263). This is consistent with Coulthard's (2014) eloquent assertion that "contemporary colonialism works through rather than entirely against freedom" (p. 156, emphasis in original).

Furthermore, recalling the two broad veins of criticism of reconciliation discourse, legalistic and aspirational, this exchange of rights is indeed what the state understands as 'reconciling' inherent and pre-existing Indigenous nationhood with unilaterally-imposed settler sovereignty (Coulthard, 2014; Henderson \& Wakeham, 2013). For example, Van der Peet (1996) recognized that Indigenous peoples lived in distinctive societies prior to colonization and articulated the need to "reconcile [this] with the assertion of Crown sovereignty over Canadian territory" (para. 43). This is important in the context of land claims settlements and selfgovernment agreements because the concept of reconciliation then functions to effectively validate the extinguishment of Aboriginal title with the stated goal of "[reconciling] aboriginal 
societies with the broader political community of which they are part" $(R v$. Gladstone, 1996, $\mathrm{p}$. 731). Consequently, under the CLCP, Alcantara (2013) maintains that "the federal, provincial and territorial governments have become rights-granting entities while [Indigenous] groups have become petitioners, forced to prove the validity of their claims to the government before they can ask the governments to cede to them land, rights, self-government, and jurisdiction” (p. 27). This process thus requires that Indigenous groups adopt "Western standards of knowledge, proof, discourse, and negotiation processes" for negotiations to be successful (Alcantara, 2013, p. 26). Recognition is therefore dependent on the ability of the First Nations groups to "engage in dialogue with wildlife biologists, lawyers, and other government officials [in order to] conform to the very particular forms and formalities of the official linguistic fields of wildlife management, Canadian property law, and so forth" (Alcantara, 2013, p. 7). David Newhouse and Yale Belanger (2001) go further and argue that because the self-government process is controlled by the federal government's policies, which are enacted via the Department of INAC, this process serves to not only limit the inclusion of "culturally-specific ideas of governance into the creation of Aboriginal self-government" (p. 39), but also to ensure that these consequent selfgoverning communities "fit neatly into [colonial institutions], all without allowing the significant transfer of decision making to the First Nations" (p. 41).

Considering the above discussion, the recognition of certain state-controlled rights in land claims settlements and self-government agreements concretely exemplifies the courts' interpretation of reconciliation, which is problematic because it is simultaneously born from and is contrary to Section 35. I argue this contradiction is consistent with how INAC employs reconciliation discourse ambiguously in news releases. These piece-meal jurisdictional concessions, I argue, are a clear assertion of the Crown's power over the entire process. This is 
particularly problematic when the respective processes are framed in terms of reconciliation because the discursive ambiguity obscures the fundamentally asymmetrical power imbalance that remains at the negotiating table between the Crown and Indigenous groups. For example, one news release related to the self-government process articulates that "[the agreement] will foster an autonomous and accountable First Nation government and also include arrangements to ensure harmonious relationships with other governments" (Item 27). Claiming that the First Nation government will be autonomous while simultaneously being held accountable to the federal government is contradictory; meso-level asymmetrical power relations are reproduced in this news release through the explicit mention of accountability measures. As Salee \& Levesque (2010) succinctly articulate, "the choices First Nations communities have to make about their future and modes of government are therefore severely limited by the hegemonic cultural framework of Canadian society and by the institutional environment in which the Canadian state forces them to operate" (p. 104). Dhillon (2017) aptly refers to this as conditional autonomy (p. 62). Moreover, the notion of 'harmonious relationships' is an aspirational invocation of reconciliation discourse; I argue that this allusion to TRC-era cultural reconciliation juxtaposes the above discussion of profoundly asymmetrical power relations in the process more broadly. Here, the notion of 'working together' works to minimize the reality that Indigenous groups have no choice (other than to leave the negotiating table empty-handed) but to comply with the stipulations or "arrangements [within the self-government agreement] that ensure harmonious relationships with other governments" (Item 27). Remember that all the while, this process extinguishes Aboriginal title as a means of 'reconciling' competing claims to sovereignty. Again, reconciliation becomes ambiguous as it is invoked implicitly in the legalistic sense and explicitly through 'harmonious relationships' in an aspirational manner. Conflating meanings of 
reconciliation in this example thus demonstrates that in practice, self-government policy indeed overtly maintains the subordination of Indigenous groups to the Crown at the negotiating table. This is done by both imposing a prescriptive framework that outlines the limited scope, nature, and extent of self-government (Irlbacher-Fox, 2009, p. 7), and promoting the process as a means of political and economic autonomy (Slowey, 2001, p. 265). Yet, the process itself both reflects and is limited to the hegemonic power relations that continue as common sense between Indigenous groups and the federal government.

This is important at a macro level because on many occasions, self-government agreements are explicitly situated within Canadian constitutionalism. The idea that "the government of Canada prefers arrangements that respect the existing constitutional and legal orders of Canada" (Alcantara \& Davidson, 2015, p. 554) is exemplified in another news article related to self-government, which describes that "the next step is provincial and federal legislation to bring the agreements into effect [and] [...] governance agreements will be harmonized with existing federal and provincial laws within the Canadian constitutional framework" (Item 32). This particular article demonstrates that colonial institutions retain the final decision-making authority to ratify the self-government agreement, despite claiming to be in 'the spirit of partnership and reconciliation.' Despite claiming to be 'nation-to-nation' negotiations, the idea that the agreements must be harmonized or 'reconciled' within existing federal and provincial laws is a clear example of the limitations of state-led rights recognition in these processes. This is important because it calls into question the overall incommensurability of decolonizing objectives within not only colonial frameworks, but also reconciliation discourse more broadly; the self-government process, like reconciliation, cannot contribute to decolonization as it neither disrupts entrenched systems of colonial power, nor does it address 
the theft of land. This logic is present in many Trudeau-era articles; notably, while the government claims to establish an equal partnership at the negotiation table through the establishment of 'government-to-government relationships,' it still explicitly mentions that the agreement nonetheless "operates within the framework of the Constitution of Canada" (Item 35). By placing these two ideas side-by-side, seemingly contradictory statement perpetuates a reconciliatory narrative, which ultimately seeks to rescue settler normalcy and settler futurity (Tuck \& Yang, 2012, p. 35).

Broadly, statements like these legitimize INAC's claim that self-government negotiations, as with negotiations related to land claims settlements, are venues that truly value Indigenous nations as sovereign nations. Yet, as I have shown, this cannot be the case in practice, however, since the framework, process, and outcome are all truly at the discretion of the Crown. In the context of SCP, Dickson (2018) argues that this conflict of interest is the policy's fundamental flaw, maintaining that the specific claims framework is "utterly devoid of the fiduciary [duty] or the honour of the Crown [and] nowhere is the absence of the trust relationship more apparent than in the Crown's deep conflict of interest in specific claims, wherein it is both a party to and arbiter of such claims" (p. 41-42). She continues her critique, articulating that most of the issues associated with the specific claims process stem from this conflict of interest whereby "the Crown, which is the party against whom a First Nation must make its claim, also determines the claim's validity and controls the process through which it is negotiated and resolved" (Dickson, 2018, p. 4). The portrayal of the relationship between the state and Indigenous nations as reconciled and 'government-to-government' is thus disingenuous: at the same time that it claims to help 'advance reconciliation,' it also validates settler futurity by subtly maintaining the subordination of Indigenous nations to colonial sovereign rule via the 
intertextual validation of the Canadian constitutional framework. Framing negotiations as major 'milestones of reconciliation' erases the unequal power dynamics at the negotiating table, and how this conflict of interest is able to allow "disingenuous government practices" (Dickson, 2018 , p. 43$)^{26}$ to continue as status quo.

\section{Theme 3: Historicizing Colonialism in Agreements}

Building on the first two themes, my final point of discussion relates to the role history plays in land claims and self-government frameworks. Specifically, I'm interested in problematizing these federal policies as tools that work to not only situate colonial violences in the past, but also absolve the current government's central role in ongoing injustices. This is similar to the critiques of the TRC-era's vision for aspirational reconciliation, which argue the concept of reconciliation fabricates a false distinction between a colonial past and a supposedly post-colonial present (Blackburn, 2007). At a macro level, historicizing settler colonialism also allows the government to create, as discussed in my Literature Review, a colonial past that starkly contrasts the present context wherein we, as a collective, have surpassed the genocidal ways of our past as the Canadian nation now exists in a supposed post-colonial era. The inaccurate construction of a post-colonial Canadian society is reinforced through reconciliation discourse and repeated in INAC news releases related to land claims settlements and selfgovernment agreements. In particular, I problematize the notion of 'renewed' or 'rebuilt' relationships between Indigenous groups and the federal government in negotiations, which is consistent with the conceptualization of reconciliation that was popularized and legitimized by the TRC. Critical scholars have argued this framing works to distinguish the current government

${ }^{26}$ As I mentioned above, the notion that the extinguishment clause is actually contrary to Section 35(1) and significant SCC decisions, for example. 
from earlier Canadian governments that explicitly sought to assimilate Indigenous identities, and instead reconstruct itself as a government that acts in good faith and in the spirit of reconciliation. While overall, this discussion draws less explicit linkages between land claims and self-government policy and news releases, it nonetheless provides an important analysis of the subtle ways that the discursive ambiguity of reconciliation facilitates the continued settler occupation of land as common sense. My analysis shows the central role that aspirational discourse plays in the otherwise substantive discussion of policy as a means to reconciliation as an end. This, in turn showcases another elucidation of how INAC, and the federal government more broadly, promotes an idea of reconciliation that is deliberately ambiguous in order to reproduce less overtly-assimilatory modes of colonial governance. As such, Dhillon argues that it is important to understand "the changing landscape of Indigenous-state relations [by establishing] a context for the rise of the state's emphasis on restoring damaged social and political relationships with Indigenous peoples through a material and discursive shift to recognition and reconciliation" (2017, p. 53).

Mirroring the critiques of TRC-era vision for aspirational reconciliation, by characterizing the relationship between the Crown and Indigenous groups as 'renewed,' I argue that INAC news releases related to land claims and self-government processes work to position colonialism definitively in the past. This perpetuates the false timeline that erases the reality that the structures of settler colonialism remain unequivocally intact despite this effort towards reconciliation through the ratification of land claims settlements and self-government agreements. As Coulthard (2014) theorizes that "in settler colonial contexts-- where there is no period marking a clear or formal transition from an authoritarian past to a democratic present-state-sanctioned approaches to reconciliation must manufacture such a transition by allocating 
the abuses of settler colonization to the dustbins of history" (p. 108). More to this point, Strakosch and Macoun (2012) maintain, this narrative "locates 'real' colonialism in the past, and assumes that policy must [now] deal with the 'legacies', 'heritage' or 'reverberative aftermath' of colonialism in today's world" (p. 43). In INAC news releases, injustices are often constructed as historical and completely separate from the present, erasing the reality that injustices are ongoing. At a micro level, I argue this is often done when INAC describes the relationship between the Crown and Indigenous groups as 'renewed' as a result of a completed agreement. In particular, three news releases highlight that "renewing the relationship with Indigenous peoples based on recognition of rights, respect, cooperation and partnership is key to achieving reconciliation $[\ldots]$ committing to renew and strengthen the nation-to-nation relationship and advancing lasting reconciliation" (Items 36, 37, and 38). However, the agreements fail to actually shift the relationship in any meaningful way that would indeed 'renew' it; framing the self-government agreements within reconciliation discourse thus contributes to constructing a the false narrative of an equal and reconciled, nation-to-nation, post-colonial relationship between the Crown and Indigenous nations. In considering what this relationship is reconciled or renewed from, one logical place to look would be historical treaties as 'recognition of rights, respect, cooperation and partnership' largely represent the spirit and intent of Numbered Treaties as nation-to-nation documents, for example. Enshrining a self-government agreement based on these original treaty responsibilities would indeed reflect RCAP's vision for substantive reconciliation. Importantly however, these particular news releases come from the West Coast, where historical treaties were not signed. The idea of renewing the relationship and achieving reconciliation in a substantive sense thus becomes unclear as these territories remain unceded 
while settlers' occupation continues largely as common sense ${ }^{27}$. What can be 'reconciled' in a territory that was simply claimed by the settler state?

In these instances, rather than addressing its role in ongoing colonial violence, by constructing the relationship between the state and Indigenous communities as 'rebuilt,' INAC news releases effectively "embeds and normalizes" these injustices deeper into federal policy (Irlbacher-Fox, 2009, p. 5) because it implies there was once a just relationship that, for unspecified reasons, now requires rebuilding. The reality is, however, reconciliation (as characterized by the TRC) continues the assimilative agenda of past governments through recognition in frameworks like self-government agreements and land claims settlements. This works to uphold colonial hegemony by simultaneously containing colonialism in the past and self-government agreements firmly within the colonial purview. Coulthard (2014) echoes these ideas, articulating:

There have been two broad criticisms of the federal government's approach to reconciling its relationship with indigenous peoples: the first involves the state's rigid historical temporal isolation of the problem in need of reconciling (colonial injustice), which in turn leads to, second, the current politics of reconciliation's inability to adequately transform the structure of dispossession that continues to frame Indigenous people's relationship with the state. (p. 120)

The notion of renewed relationships, much like nation-to-nation negotiations, is situated in reconciliation discourse and contributes to both its ambiguity and to the ways in which it erases the Crown's continued problematic relationship with Indigenous peoples as subordinate. This reconciliatory narrative conceals from the very real ways that the relationships remain fundamentally asymmetrical and based on white supremacist logics that form the foundation of both the Indian Act and the Canadian Constitution. Like reconciliation, these federal frameworks

${ }^{27}$ Could reference Wetsu'wet'en here as a current problematization of unceded territories as unreconciled with Canadian sovereignty writ large. 
focus on symptoms of injustice, like particularly destructive policies such as those that enacted the IRSS or the Indian Act, and distract from the ways that dispossession is the source of injustice, which, as a structure, continues untouched (Irlbacher-Fox, 2009). Self-government agreements, like land claims settlements, do not subvert these coercive and violent power dynamics, but rather serve to reinforce them by subsuming and assimilating Indigenous identity deeper into the folds of the Canadian constitutional order.

Another example of this narrative of renewal describes "successful completion of treaty and self-government agreement negotiations [as] key to advancing reconciliation with Indigenous communities in Canada and are an important path to improving the quality of life and self-sufficiency" (Item 26). This news release centres reconciliation as improvement via selfgovernment agreements, which ignores the fact that "struggles for stolen land are ongoing, Indigenous children continue to be found in state care at disproportionate rates, colonial violence continues and can be seen at high numbers of missing and murdered Indigenous women and girls" (George, 2017, p. 55). In essence, the government's role in self-government negotiations, as portrayed in this news release in typical White Saviourism ${ }^{28}$, is to undo "an encountered dysfunction that is unmodern and not of the government's making" (Irlbacher-Fox, 2009, p. 34); this convenient amnesia masks the historical and ongoing genocidal violence that is coordinated through federal policies and instead pushes the notion that "governmental help will result in modernity of happiness, wellness, and assimilated "normalcy"' (Irlbacher-Fox, 2009, p. 34). Consequently, this allows the state-led self-government process to become "a source of social,

${ }^{28}$ In brief, white saviourism refers to the idea that a white person (or Western culture, broadly) can and will rescue people of colour from oppression. For more, refer to Cole, T. (2012, March 21). The White-Saviour industrial complex. The Atlantic. Retrieved from https://www.theatlantic.com/international/archive/2012/03/the-white-savior-industrialcomplex/254843/. 
political, and material redemption [and] the state manages to legitimize both injustice and its ongoing colonial-based interventions into the lives of Indigenous peoples" (Irlbacher-Fox, 2009, p. 2). The state-led self-government process is portrayed as a pragmatic remedy to these 'historical' injustices, but in no way actually addresses not only the fact that these injustices persist, but more importantly, that the source of these injustices is structural land dispossession. Consequently, INAC news releases focus on the lack of self-government as the source of injustice, completely erasing the ways in which access to land and self-government are interrelated. This is important to note because, as Pasternak (2017) underlines, land restitution and Indigenous jurisdiction work together because "without land, there is no meaningful governance to speak of"' (p. 52).

These examples elucidate how the land claims and self-government processes are able to account for one particular injustice rather than address the larger, unjust system of ongoing structural dispossession. As part of a larger reconciliation discourse, the notion of renewed relationships exemplifies the federal government's ability to take responsibility for a small instantiation of settler colonial violence, rather than addressing "the continued Canadian sources of $[\ldots]$ harm such as land dispossession, structural poverty, and overincarceration" (James, 2017, p. 379) that persist. What is more, Stephanie Irlbacher-Fox (2009) theorizes that "by conflating specific unjust events, policies, and laws with 'history,' what is unjust becomes temporally separate from the present, unchangable. This narrows the options for restitution: we cannot change the past, shifting pursuits of substantive restitution to symbolic" (p. 33). This is the logic behind historicizing colonialism: I argue that this symbolic restitution takes the form of reconciliation, much like the aspirational goals of the TRC's vision for reconciliation that encourage mending relationships and "moving forward together in a spirit of reconciliation and 
renewal" (Item 4), for example, which fail to make the crucial connection between the policy and the larger issue of structural dispossession in Canada as an all-encompassing, nation-founding project that continues today. Practically, however, described again as "a key step on a path to reconciliation" (Item 8), the goal of reconciliation in federal land claims process is to resolve all outstanding Indigenous claims to land. As I have already discussed, this is problematic because the logic of recognition in the claims process aims to distract from the reality that settlements serve the assimilatory purpose of extinguishing all Indigenous claims to land that exist outside of Canadian constitutionalism. Reconciliation contributes to validating these logics because, as an ambiguous political concept, it is not at all involved in repatriating in land or meaningfully addressing how colonial violence continues today. 


\section{Conclusion: Reconciliation is Not a Metaphor}

As can be seen, reconciliation discourse is both deeply complicated and highly contested. The problematic logics inherent to the state's vision for reconciliation have been detailed at length by engaging with both Indigenous and settler scholars from Turtle Island and beyond. By focusing on INAC as a particular site for colonial violence, this project sought to critically analyse the ways in which this instantiation of settler governmentality operationalizes reconciliation discourse in news releases to maintain status quo settler colonial occupation of stolen Indigenous land. In narrowing the focus to policies related to land claims settlements and self-government agreements, my critical analysis worked to centre the repatriation of Indigenous land as a fundamental and incommensurable imperative. My discussion centred the insights of Coulthard (2014) and Alfred and Corntassel (2005), and showcased themes of certainty, Crown authority, and history in INAC news releases. In directly addressing my research question, these themes highlight the extent to which logics of dispossession and elimination are indeed ingrained in state-controlled reconciliation discourse and perpetuated both discursively in news releases and practically in policy implementation.

Broadly, though, I found that the concept of reconciliation is used in a multitude of different rhetorical and discursive ways in the corpus and serves just as many different political functions in the interests of upholding settler colonialism in Canada. In half of the sample items, it is described as something to be advanced or achieved, or in almost a quarter of the items, it is described in terms of a journey, path, or step to be worked towards. At times, it is a spirit, it is a process, and it is a tool. Reconciliation is described as a matter of rebuilding or renewing relationships and it can signify respect or healing. My findings show that reconciliation is never 
used in the substantive sense, but rather always is invoked as an aspirational, affective phenomenon. Cree poet and scholar Billy-Ray Belcourt (2016) articulates:

Reconciliation, at once a heuristic and a form of statecraft, fakes a political that doesn't actually exist as such, one that not only presupposes that [Indigenous peoples] are willing to stay attached to it [...] Reconciliation wants so badly to be a keyword of sorts, to contain so much inside its semantic confines, [...] I'm not surprised things have started to leak all over the place.

In INAC news releases, framing the land claims and self-government processes within the context of reconciliation discourse is particularly dangerous for Indigenous resurgence because as Dhillon (2017) articulates, "past configurations of state control over the lives of Indigenous people, with their vestiges of overt domination and civilizing undercurrents, give way to a 'politics of inclusion' imbued with the symbolic language and normative assertions of participation and 'working together'” (p. 11-12). For example, one news release describes the land claims settlement as "a historic milestone in the spirit of reconciliation," and articulates that the process more broadly works to "[advance] reconciliation with First Nations" (Item 3). By characterizing reconciliation as an essence or 'spirit' in the former, and as an agenda to be 'advanced' in the latter, this news release invokes themes of relationship-building between Indigenous peoples and settlers, or as the TRC envisioned, "establishing and maintaining a mutually respectful relationship between Aboriginal and non-Aboriginal peoples" ("Volume 6," 2015, p. 3). As I discussed at length, characterizing reconciliation in an aspirational manner not only erases the ways in which colonial violence continues today, but also because it places the onus on "Indigenous subjects [as] the primary object of repair, not the colonial relationship" (Coulthard, 2014, p. 127) and thus avoiding a significant interrogation of both structural land theft and the ongoing project of settler colonialism. To this end, despite this idea of 'moving forward together in reconciliation' through the settlement of land claims, the power relations 
between the Crown and these First Nations communities is unchanged. Because access to land is conditional to the terms of the agreements, the Crown continues to truly dictate -- and, as a result of the settlements, will forever dictate via legal certainty-- how these First Nations communities access and interact with the land. George (2017) supports this notion and warns that "reconciliation as advanced by the state is nothing but a pretty window dressing for the new and more insidious manifestation of assimilation: social inclusion" (p. 56).

I argue that it is hard for reconciliation to be meaningful when it is at once a journey, a path, a milestone, a framework, a tool of economic development, a spirit, a process, and so on. This deliberate ambiguity renders it utterly meaningless; the state's vision for reconciliation is able to effortlessly shape-shift into whichever interpretation conveniently serves any given political context while effectively skirting any substantive acknowledgment or disruption of settler colonial governmentality. These broad and diverse uses for reconciliation moved me to further refine my research question. I maintain that an allusive, shape-shifting concept like reconciliation facilitates a politically acceptable post-TRC-era expansion of settler colonial governmentality whereby recognition (read: assimilation) is strictly contained within the capitalist, colonial reality. As Belcourt (2016) continues, "reconciliation is stubbornly ambivalent in its potentiality, an object of desire that we're not entirely certain how to acquire or substantiate, but one that the state - reified through the bodies of politicians, Indigenous or otherwise - is telling us we need." A reconciliatory, 'renewed relationship' serves to absolve the government of its central role in historical and ongoing violence and genocide and erases any connection between the pervasive manifestations of settler colonialism such as social inequalities between Indigenous peoples and settlers in Canada and the theft of Indigenous land. As can be seen in the example above, "while removing [...] barriers to accessing land, settler 
governmentality in Canada relies upon colonial tools of dispossession while simultaneously constructing its own post-colonial narrative to celebrate itself as a new nation that is free from the colonial past" (Crosby \& Monaghan, 2012, p. 425). Reconciliation is, in a characteristically Canadian fashion, a colonial tool of dispossession that works through land claims settlements and self-government agreements. I argue that reconciliation is metonymic for polite colonial violence and is used to uphold the many systems of power that work to facilitate continued access to stolen Indigenous lands and ensure settler futurity. This normalized violence continues unchanged and accepted as common sense; this 'renewed relationship' fails to take responsibility for centuries of dishonoured treaties, cultural genocide via violent federal policies like the IRS, the 60s Scoop, current child welfare policies, and the thousands of missing and murdered Indigenous women, girls, and two-spirit folks. This vision for reconciliation does not account for the ways in which normalized settler colonial violence against Indigenous peoples continues as status quo every single day that occupation continues.

With the findings of my critical analysis in mind, however, I wish to elucidate a number of important concluding considerations. Is it possible to amend the state's current vision of reconciliation to contribute to productive movements towards Indigenous resurgence and decolonization? Recalling McMahon's (2019) suggestion sees the reconceptualization of reconciliation in terms of biskaabiyiing, Manuel (2017) articulates that "many Canadians want to see reconciliation between the settlers and Indigenous peoples. But that cannot be forced. Reconciliation has to pass first through truth. And we still have not had enough of that from this government or from Canada as a whole" (p. 56). There thus requires a genuine and profoundly unsettling reckoning of Canada's history-- understanding that at its core, this country exists at the 
expense of Indigenous bodies, cultures, and lands, which has yet to take place. As Leanne

Simpson (2016) importantly maintains,

If reconciliation is to be meaningful, we need to be willing to dismantle settler colonialism as a system. Our current government needs to move beyond window dressing and begin to tackle the root causes of Indigenous oppression in Canada. This means respecting when Indigenous peoples say no to development on our lands. It means dismantling land claims and self government processes that require us to terminate our Aboriginal and treaty rights to sit at the table. It means repealing the most damaging aspects of the Indian Act and respecting First Nations political systems, governance, and ability to determine who belongs in our communities. It means being accountable about the collective damage that has been done and is being done, and supporting the regeneration of languages, cultures, and political systems. It means stop fighting us in court. It means giving back land, so we can rebuild and recover from the losses of the last four centuries and truly enter into a new relationship with Canada and Canadians.

My findings show that reconciliation is problematic because it is simply aspirational. This is echoed throughout my Literature Review by countless critical scholars. What is substantive reconciliation, then? The 1996 Gathering Strength report published by the Royal Commission on Aboriginal Peoples suggests reconciliation should encompass a return to treaty responsibilities and a become bridge between historical and ongoing violences through principles of transitional justice. More than twenty years later, what does it mean that advancing land claims settlements and self-government agreements is the federal government's main way of quantifying its commitment to reconciliation? The government's vision for reconciliation largely has to do with extinguishing Aboriginal rights and title and conveniently forgiving and forgetting.

Reconciliation has to stop being a spirit or a path or a milestone and start being a disruption to colonial structures. And this is the crux of the issue with ambiguity.

As a communications scholar, I understand that language as ambiguous and I am not necessarily arguing for a normative understanding of reconciliation. However, as I mentioned much earlier, the federal government is not understood (in mainstream thinking, at least) to be in the business of public relations or marketing in these news releases, but instead to be 
communicating policy decisions or settlements, for example, that are based on court rulings and laws. This is where I see the problem: the conveniently allusive meaning of the word reconciliation is spun positively, while that ambiguity in political contexts actually "[enables] politicians to blur or hide problematic implications of controversial decisions" (Fischer, 2009, p. 175), such as the ones uncovered in my analysis. My findings show that when INAC operationalizes reconciliation discourse, if often does so in a way that portrays reconciliation as a substantive solution, yet it simultaneously reproduces the problematic, aspirational rhetoric that functions to historicize colonialism, assimilate Indigenous identity, and perpetuate colonial occupation as status quo.

Just as Tuck and Yang (2012) compellingly argue that decolonization should not be used as a metaphor, but instead reflect true movements of repatriation of land and Indigenous resurgence, I argue that the only way reconciliation can truly work towards the restoration of good relations is through action. To this, I challenge: reconciliation should no longer be used as a metaphor. As Lee (2016) stresses:

Reconciliation as the restoration of good relations. Restoring good relations requires fundamentally breaking with a vastly unjust world to a focus on how we relate to each other and the world around us. [...] Reconciliation is no more Indigenous kids dropping out of university because they can't afford it. It is Canadian courts ceasing to prosecute Indigenous land defenders for shutting down pipelines on our own territories. It is all missing Indigenous women and girls returned home. Reconciliation is recognizing that migrant lives are worth more than borders. It is opportunities to learn Indigenous languages. Reconciliation is \#IdleNoMore. Reconciliation is \#BlackLivesMatter. Reconciliation is funding that reflects the amount of reparations owed by governments, and the abolition of colonial systems of policing. It is mining corporations shutting their doors and paying every last cent of their worth into rebuilding devastated habitats. Reconciliation is the end of queer and trans Indigenous youth driven to suicide by a colonial state that cannot contain their multitudes. It is the end of poverty, homelessness and hunger, the end of sexual violence, the end of colonial violence. Reconciliation is the realization of worlds that should have been. 
With this in mind, the flaws in the state's shallow vision for reconciliation become abundantly clear when the same Prime Minister who trumpeted these 'sunny ways' also smugly and sarcastically thanks an Indigenous woman for her donation to the Liberal Party of Canada as he has her forcibly removed from a March 2019 fundraising event after she unfurled a banner that drew attention to the ongoing crisis of mercury contamination at Asubpeeschoseewagong First Nation (also known as Grassy Narrows) in northern Ontario. The outright callousness of the Prime Minister's disregard for acknowledging-- let alone truly addressing-- the colonial systems of violence is indicative of the broader implications of state-led reconciliation politics: after thanking the woman for her donation, Trudeau asserts "that is why we are moving forward on reconciliation in a real and tangible way [...] thank you for highlighting how important reconciliation is" (Maloney, 2019). This vision of reconciliation is not only superficial, but it also truly legitimizes ongoing violences. Reconciliation not only fails to address the very real ways that settler colonial hegemony violates every single aspect of Indigenous life in the land now known as Canada, but it also deliberately obscures and erases this reality in order to maintain unfettered access to stolen lands from coast to coast to coast.

It is clear that the way to move beyond aspirational rhetoric towards substantive reconciliatory action is a return to treaty responsibilities, as RCAP envisioned. The current policy frameworks related to land claims settlements and self-government agreements work towards reconciliation as a determined end-point by "[reaching] a full and final settlement of all the outstanding issues" (Item 21) and "[righting] past wrongs [...] once and for all " (Item 20). In practice, these processes extinguish Aboriginal rights and title and terminate the relationship between the Crown and Indigenous groups. Yet in contrast to the 'final and certain' objectives of these frameworks, treaties are living documents that evolve and grow through time and represent 
an ongoing relationship based on mutual respect and understanding (Lawrence, 2012, p. 73). It is time to rethink the end-point of this supposed 'journey' toward reconciliation and instead move towards the unambiguous notions of reciprocity and relationality that are so indispensable for moving forward together in a good way, on an ongoing basis (McMahon, 2019). 


\section{Appendix I: Expanded Method}

\section{Initial Coding Framework}

II. Identifying framing (see Huckin, as cited in Grbich, 2013, p. 252)

a. Note structural elements of text (manifest content)

b. Identify which general topic is present

c. Identify whose voices are used and whose are missing (latent content)

III. Interpretation (see Harding, 2005, 2017)

a. Who is depicted as powerful and who is passive? Who has agency?

b. Note use of:

- Verb choice

- Connotations

- Hedging

- Pronouns

- Ambiguous meanings (Fischer, 2009)

- Stereotypes and tropes

- Essentialization

- Other literary/rhetorical devices

c. What is the register that is adopted? Optimistic, sceptic?

d. Are there declarative statements/assertions?

- Which statements are taken for granted as fact?

- Which concepts are accepted as truth and/or common sense?

IV. Theoretical memos (see Strauss, as cited in Grbich, 2013, p. 85)

a. What does reconciliation stand in for? Is it substantive or aspirational?

b. Which narrative takes priority in each document? What story is the government trying to tell? How do these individual narratives contribute to a larger pattern of discourse?

c. How does this piece work within larger narratives in Canada and are there shifts taking place?

- Which shared beliefs and values are being transmitted?

- How do these values fit within a shared understanding of Canadian identity?

d. Is there any mention or contextualization of colonial history?

- Assumptions and omissions made 


\section{Creating and First Coding of the Sample}

This section discusses the methods through which I carried out my critical analysis of INAC public news releases. I will first discuss my rationale for selecting this particular research site, my method of data collection, the development of my coding framework, and the coding process for my corpus.

In brief, my initial phase of data collection required I amass my corpus. In brief, an example of search criteria I used on the Government of Canada archives website for 2017 was as follows:

News type: news release Institution: INAC Minister: all Start date: $2017-01-01$

End date: $2017-10-01$

I replicated the criteria for the years of 2016-2009, modifying only the end dates as reflecting December 31, to ensure a full year included in the search. Moreover, the criteria for 2008 was modified to represent an end date of June 30. I will discuss the significance of each of the criteria specifically below.

Firstly, I limited my search query on the Government of Canada online archives to news releases, as these pieces were written for the specific target audience of the wider Canadian public. In brief, these pieces are deliberately public-facing and represent the story that the government wants its citizens to know. News releases are, in essence, management of public opinion on topics that range from policy announcements, government initiatives, and government-sponsored events. While they are not necessarily policy documents, they are indeed political discourse as a reflection of the policy-making process. These statements are meant to be 
the public's window into governmental decision-making, and therefore can be useful for interpreting the government's strategic policy direction relating to Indigenous peoples.

Moreover, born from Section 91(24) of The Constitution Act, 1867, INAC (in its many acronomic iterations) is the primary Federal entity that is responsible for "Indians, and the lands of Indians" (The Constitution Act, 1867). INAC is a logical site for this analysis as it is the primary interlocutor between the Federal government and Indigenous peoples in Canada; interrogating the policy direction of INAC is thus an obvious starting place to understand how the government continues its unquestioned occupation of the lands now known as Canada. I kept the minister criteria open-ended, as I felt a diverse representation of Federal departments interacting with INAC would be interesting, and in the end, did not affect the results very much.

Lastly, limiting my analysis from June 30, 2008 to October 10, 2017 is not an arbitrary decision: under the Harper government, the TRC was established in June 2008 and thus seems like a reasonable place to start my analysis. Since 2008, and especially since Prime Minister Justin Trudeau was elected in 2015, the concept of reconciliation has generally become more and more prominent within the Canadian consciousness. Moreover, in October 2017, Prime Minister Justin Trudeau announced that INAC would dissolve into two newly-created Federal departments (CIRNAC and ISC) with new respective responsibilities. The implications of this structural shift will likely be far-reaching, but formal announcements from the Prime Minister have yet to be made about the changes. Thus, 2008-2017 is a manageable and relevant time frame for my analysis of INAC public news releases.

With these criteria, my preliminary search yielded over 1,200 results. To refine these results to a more manageable number, I worked from year to year. I went through each news release and did a keyword search for reconciliation. I began by flagging items with the word 
'reconciliation' in the main body of the article, and excluded articles that only contained reconciliation in the title, in direct quotes, or in the 'background' part of the news release as I do not feel they contribute to the kind of questions I am asking about this particular instantiation of political discourse. I also excluded articles that referred only to reconciliation as a proper noun, such as the TRC, or within an individual's professional title like the Government of British Columbia's Ministry of Indigenous Relations and Reconciliation, for example. I conducted a total of two full passes through the initial data set and ended up with a total of 98 articles for my CDA. Note that this preliminary survey did not include any analysis of the articles' content, but simply a generic search for the word 'reconciliation' in the main text.

With a manageable amount of data materials for my corpus, my next step was to reconcile the results of the first and second database passes into one chart in reverse chronological order. I then sorted the 98 pieces into three broad themes on the chart: land claims and treaties; Residential Schools and TRC; and other. I felt that those two initial themes were the most prevalent topics associated with reconciliation based on my initial collection and could be an interesting way to refine my topic. Moreover, to easily identify shifts in discourse throughout the years, I colour coded each year on the chart. I then printed my corpus in a binder. I organized each article first by theme, then placed them in reverse chronological order.

Broadly, then, I methodically applied techniques of CDA to these 98 public news releases issued by INAC between the years 2008-2017. Before the first-pass of coding, I developed a detailed coding sheet that I used for analysing each news release. I initially drew on Huckin's framework of first identifying framing then interpretation (as cited in Grbich, 2013, p. 252). I also drew on Harding's (2005) coding prompts for both manifest and latent content (p. 319-324). Then, in keeping with Straussian methods of grounded theory, I wrote brief theoretical memos 
for each article after the first pass of coding (as cited in Grbich, 2013, p. 85). These memos are important to my method in grounded theory as they allow me to generate preliminary questions, hypotheses, and explore important concepts and trends that emanate through the coding process. For my first pass of several iterative steps of coding, I focused especially on the micro-level of the text itself and noted first thoughts about the meso-level of manoeuvres and claims of authority. For reference, my coding method is attached as Appendix I.

Next, as a means of focusing specifically on my defined research question, I limited my second round of coding to articles related to land claims settlements and self-government agreements, which amounted to a total of 39 articles, listed in Appendix II. Eliminating articles related to the IRS and the TRC allowed me to better address how reconciliation discourse works to effectively uphold the dispossession and displacement of Indigenous peoples from their lands. Furthermore, consistent with my theoretical and methodological underpinnings, I understand that settler colonialism is inherently related to the theft of land. Because land claims settlements and self-government agreements engage directly with issues of land, they are thus logical sites for precision. I argue that self-government agreements and land claim settlements are instruments of colonial occupation that operate within the reconciliation paradigm and function to entrench settler colonial hegemony through tools of recognition and distraction. During this second round of coding, I focused on four broad narrative themes: accountability discourse, tools of containment, economic development rhetoric, and discourses of improvement. While they first emerged in my preliminary findings, I used these organizing themes iteratively to then consider how INAC operationalizes reconciliation discourse to maintain unquestioned occupation of Indigenous lands. 
I also incorporated supervisory and other feedback from early analyses, alongside expanded reviews of research, to produce two new contextualizing factors that considered the history of land claims settlements and self-government agreements. Critical research on these policies consequently informed my third round of coding, which allowed me to focus on more nuanced themes of agency and power, in the context of Coulthard's (2014) recognition paradigm and Alfred and Corntassel's (2005) politics of distraction. Ultimately, the aim was to simultaneously balance all three of the micro-, meso-, and macro-levels of discourse, the syntactical usage, claims to power, and socio-cultural context, respectively (Fairclough, 1995, recalling pp. 48-49 above). This is an iterative project that uses a grounded approach; the reorganization of my Analysis section as a result of further reading and coding therefore allowed me to make more explicit connections between my theory and findings and engage in a deeper discussion about the knowledge that INAC news releases produce about these colonial policies when they are framed in reconciliation discourse. 


\section{Appendix II: Sample of News Releases from Indigenous and Northern Affairs Canada}

\section{On Land Claims Settlements}

1. Canada, Ontario and Rainy River First Nations announce new reserve creation. (2017, May 19). Retrieved from https://www.canada.ca/en/indigenous-northern-

affairs/news/2017/05/canada_ontario_andrainyriverfirstnationsannouncenewreservecreati .html.

2. New reports provide paths forward on outstanding land claims in Northwest Territories. (2017, April 6). Retrieved from https:/www.canada.ca/en/indigenous-northernaffairs/news/2017/04/new_reports_providepathsforwardonoutstandinglandclaimsinnorth wes.html.

3. Canada, Ontario and Williams Treaties First Nations take first step towards a negotiated resolution of Alderville litigation. (2017, March 27). Retrieved from https://www.canada.ca/en/indigenous-northernaffairs/news/2017/03/canada_ontario_andwilliamstreatiesfirstnationstakefirststeptowar.ht $\mathrm{ml}$.

4. Canada and the Siksika Nation Advance Reconciliation with Signing of Castle Mountain Settlement. (2017, January 25). Retrieved from https://www.canada.ca/en/indigenousnorthern-affairs/news/2017/01/canada-siksika-nation-advance-reconciliation-signingcastle-mountain-settlement.html.

5. Algonquins of Ontario achieve new milestone toward modern treaty with Ontario and Canada. (2016, October 18). Retrieved from https://www.canada.ca/en/indigenousnorthern-affairs/news/2016/10/algonquins-ontario-achieve-new-milestone-towardmodern-treaty-ontario-canada.html.

6. Canada, Ontario and Chapleau Cree First Nation Celebrate Settlement of Land Claim. (2016, September 17). Retrieved from https://www.canada.ca/en/indigenous-northernaffairs/news/2016/09/canada-ontario-chapleau-cree-first-nation-celebrate-settlementland-claim.html.

7. Canada and Blood Tribe Celebrate Key Milestone on Path of Reconciliation and Renewal. (2016, July 16). Retrieved from https://www.canada.ca/en/indigenous-northernaffairs/news/2016/07/canada-and-blood-tribe-celebrate-key-milestone-on-path-ofreconciliation-and-renewal.html.

8. Canada and Chippewas of Kettle and Stony Point Take Key Step in their Journey Toward Healing and Reconciliation with Historic Camp Ipperwash settlement. (2016, April 14). Retrieved from https://www.canada.ca/en/indigenous-northernaffairs/news/2016/04/canada-and-chippewas-of-kettle-and-stony-point-take-key-step-intheir-journey-toward-healing-and-reconciliation-with-historic-camp-ipperwashsettlement.html.

9. Canada and Metepenagiag Mi'kmaq Nation Sign Settlement Agreement of the 1895 Surrender Specific Claim. (2014, April 22). Retrieved from https://www.canada.ca/en/news/archive/2014/04/canada-metepenagiag-mi-kmaq-nationsign-settlement-agreement-1895-surrender-specific-claim.html.

10. Harper Government and the Chippewas of the Thames First Nation Conclude Historic Specific Claim Settlement. (2013, December 9). Retrieved from 
https://www.canada.ca/en/news/archive/2013/12/harper-government-chippewas-thamesfirst-nation-conclude-historic-specific-claim-settlement.html.

11. Canada and Tsuu T'ina Nation Reach Final Agreement on Historic Claims. (2013, July 6). Retrieved from https://www.canada.ca/en/news/archive/2013/07/canada-tsuu-t-inanation-reach-final-agreement-historic-claims.html.

12. Harper Government Improves First Nation Specific Claims Settlement Process. (2013, March 7). Retrieved from https://www.canada.ca/en/news/archive/2013/03/harpergovernment-improves-first-nation-specific-claims-settlement-process.html.

13. Canada and the Mohawks of Akwesasne Finalize Kawehnoke-Easterbrook Settlement Agreement. (2012, October 17). Retrieved from https://www.canada.ca/en/news/archive/2012/10/canada-mohawks-akwesasne-finalizekawehnoke-easterbrook-settlement-agreement.html.

14. Coldwater-Narrows Specific Land Claim Ratification Vote. (2012, July 16). Retrieved from https://www.canada.ca/en/news/archive/2012/07/coldwater-narrows-specific-landclaim-ratification-vote.html.

15. Canada and Mohawks of Akwesasne Conclude Negotiations on Kawehnoke Claim. (2012, February 21). Retrieved from https://www.canada.ca/en/news/archive/2012/02/canada-mohawks-akwesasne-concludenegotiations-kawehnoke-claim.html.

16. Canada, Ontario and Fort William First Nation Celebrate Historic Land Claim Settlement. (2011, December 16). Retrieved from https://www.canada.ca/en/news/archive/2011/12/canada-ontario-fort-william-first-nationcelebrate-historic-land-claim-settlement.html.

17. Ron Doering appointed as Chief Federal Negotiator on Algonquins of Ontario Land Claim Talks. (2011, June 10). Retrieved from https://www.canada.ca/en/news/archive/2011/06/ron-doering-appointed-chief-federalnegotiator-algonquins-ontario-land-claim-talks.html.

18. Canada and Four Ontario First Nations Take Major Step Toward Claim Settlement. (2011, May 26). Retrieved from https://www.canada.ca/en/news/archive/2011/05/canadafour-ontario-first-nations-take-major-step-toward-claim-settlement.html.

19. Canada and the Caldwell First Nation Achieve Win-Win Solution to Conclude Longstanding Claim. (2011, March 25). Retrieved from https://www.canada.ca/en/news/archive/2011/04/canada-caldwell-first-nation-achievewin-win-solution-conclude-longstanding-claim.html.

20. Canada and the Mississaugas of the New Credit First Nation Celebrate Historic Claim Settlement. (2010, October 29). Retrieved from https://www.canada.ca/en/news/archive/2010/10/canada-mississaugas-new-credit-firstnation-celebrate-historic-claim-settlement.html.

21. Canada Moving Forward on Camp Ipperwash Negotiations. (2008, August 22). Retrieved from https://www.canada.ca/en/news/archive/2008/08/canada-moving-forward-campipperwash-negotiations.html.

22. Canada, Seton Lake Indian Band and Province of British Columbia Reach Final Agreement on Settlement. (2008, March 17). Retrieved from https://www.canada.ca/en/news/archive/2008/03/canada-seton-lake-indian-bandprovince-british-columbia-reach-final-agreement-settlement.html. 


\section{On Self-government Agreements}

23. Canada and Tsleil-Waututh Nation take steps to advance reconciliation with signing of Letter of Understanding. (2017, September 4). Retrieved from https://www.canada.ca/en/indigenous-northern-affairs/news/2017/09/canada_and_tsleilwaututhnationtakestepstoadvancereconciliationw.html.

24. Canada and the Crees of Eeyou Istchee Sign Agreement on Cree Nation Governance. (2017, July 18). Retrieved from https:/www.canada.ca/en/indigenous-northernaffairs/news/2017/07/canada_and_the_creesofeeyouistcheesignagreementoncreenationgo ver.html.

25. Tulita, Canada and GNWT Negotiators initial Self-Government Agreement-in-Principle. (2017, May 17). Retrieved from https://www.canada.ca/en/indigenous-northernaffairs/news/2017/05/tulita_canada_andgnwtnegotiatorsinitialself-governmentagreement.html.

26. Canada and Whitecap Dakota First Nation Sign Agreement-in-Principle on Selfgovernment, a Major Milestone on Path to Reconciliation. (2017, April 27). Retrieved from https://www.canada.ca/en/indigenous-northernaffairs/news/2017/04/canada_and_whitecapdakotafirstnationsignagreement-inprincipleon.html.

27. Reconciliation in Action: Minister Bennett and Chief Slett Sign the Heiltsuk Hai' ¿ci'stut Framework Agreement for Reconciliation. (2017, January 28). Retrieved from https://www.canada.ca/en/indigenous-northern-affairs/news/2017/01/reconciliationaction-minister-bennett-chief-slett-sign-heiltsuk-stut-framework-agreementreconciliation.html.

28. Tsilhqot'in and Canada Take First Steps towards Reconciliation with Signing of Letter of Understanding. (2017, January 27). Retrieved from https://www.canada.ca/en/indigenous-northern-affairs/news/2017/01/tsilhqot-canadatake-first-steps-towards-reconciliation-signing-letter-understanding.html.

29. Government of Canada Supports Advancing Treaty and Self-Government Negotiations in the Northwest Territories through Ministerial Special Representative Appointments. (2016, July 19). Retrieved from https:/www.canada.ca/en/indigenous-northernaffairs/news/2016/07/government-of-canada-supports-advancing-treaty-and-selfgovernment-negotiations-in-the-northwest-territories-through-ministerial-specialrepresentative-appointments.html.

30. Canada and Manitoba Metis Federation Celebrate Key Milestone on Road to Reconciliation (2016, November 15). Retrieved from https://www.canada.ca/en/indigenous-northern-affairs/news/2016/11/canada-manitobametis-federation-celebrate-key-milestone-road-reconciliation.html.

31. Wuikinuxv Nation, Canada and British Columbia Sign Agreement-Principle towards Final Treaty. (2015, July 23). Retrieved from https://www.canada.ca/en/news/archive/2015/07/wuikinuxv-nation-canada-britishcolumbia-sign-agreement-principle-towards-final-treaty.html.

32. Five Te'mexw Member First Nations, Canada and British Columbia Sign an AgreementPrinciple towards Final Treaties on Vancouver Island. (2015, April 9). Retrieved from https://www.canada.ca/en/news/archive/2015/04/five-te-mexw-member-first-nations- 
canada-british-columbia-sign-agreement-principle-towards-final-treaties-vancouverisland.html.

33. Harper Government Introduces Legislation to Ratify the Tla'amin Final Agreement, and it is Passed at all Stages in the House of Commons (2014, April 28). Retrieved from https://www.canada.ca/en/news/archive/2014/04/harper-government-introduceslegislation-ratify-tla-amin-final-agreement-it-is-passed-all-stages-house-commons.html.

34. Nine First Nations Sign Agreement to Assume Greater Control Over their Land. (2013, December 12). Retrieved from https://www.canada.ca/en/news/archive/2013/12/ninefirst-nations-sign-agreement-assume-greater-control-their-land.html.

35. Self-Government Agreement-Principle signed with Miawpukek First Nation: A renewed relationship based on trust and mutual respect. (2013, November 8). Retrieved from https://www.canada.ca/en/news/archive/2013/11/self-government-agreement-principlesigned-miawpukek-first-nation-renewed-relationship-based-trust-mutual-respect.html.

36. Canada, Manitoba and Sioux Valley Dakota Nation Sign First Self-Government Agreements in Prairies. (2013, August 30). Retrieved from https:/www.canada.ca/en/news/archive/2013/08/canada-manitoba-sioux-valley-dakotanation-sign-first-self-government-agreements-prairies.html.

37. Canada, Yale First Nation and the Province of BC Sign the Yale First Nation Final Agreement. (2013, April 13). Retrieved from https://www.canada.ca/en/news/archive/2013/04/canada-yale-first-nation-province-bcsign-yale-first-nation-final-agreement.html.

38. The Harper Government and Whitecap Dakota First Nation Celebrate signing of Framework Agreement on Self-government. (2012, January 25). Retrieved from https://www.canada.ca/en/news/archive/2012/01/harper-government-whitecap-dakotafirst-nation-celebrate-signing-framework-agreement-self-government.html.

39. First Urban Treaty in B.C. History Takes Effect Today. (2009, April 3). Retrieved from https:/www.canada.ca/en/news/archive/2009/04/first-urban-treaty-b-c-history-takeseffect-today.html. 


\section{Bibliography}

Absolon, K., \& Willett, C. (2005). Putting ourselves forward: Location in Aboriginal Research. In Brown, L. A., \& Strega, S. (Eds.), Research as resistance: critical, indigenous and anti-oppressive approaches (chapter 2). Toronto, ON: Canadian Scholars' Press/Women's Press.

Aboriginal Affairs and Northern Development Canada (AANDC). (2012). Self-government. Government of Canada. Retrieved from: www.aadncaandc.gc.ca/eng/1100100032275/1100100032276.

Alcantara, C. (2013). Negotiating the deal: Comprehensive land claims agreements in Canada. Toronto: University of Toronto Press.

Alcantara, C., \& Davidson, A. (2015). Negotiating Aboriginal self-government agreements in Canada: An analysis of the Inuvialuit experience. Canadian Journal of Political Science. 48(3): 553-575.

Alfred, T., \& Corntassel, J. (2005). Being Indigenous: Resurgences against contemporary colonialism. Government and Opposition, 40(4), 597-614.

Baldwin, A. (2012). Whiteness and futurity: Toward a research agenda. Progress in Human Geography, 36(2), 172-187.

Bedford, D. (2010). Emancipation as oppression: The Marshall decision and self-government. Journal of Canadian Studies, 44(1), p. 206-220.

Belanger, Y. (2008). Aboriginal Self-Government in Canada. Saskatoon: Purich Publishing.

Belcourt, B-R. (2016, January 15). Political depression in a time of reconciliation. Active History. Retrieved from http://activehistory.ca/2016/01/political-depression-in-a-time-ofreconciliation/\#_ftn6.

Blackburn, C. (2007). Producing legitimacy: Reconciliation and the negotiation of Aboriginal rights in Canada. Journal of the Royal Anthropological Institute, 13(3), 621-628.

Calder et al. v. Attorney-General of British Columbia. (1973). SCR 313.

Canel, M.J. \& Sanders, K. (2012). Government communication: An emerging field in political communication research. In Semetko, H. A., \& Scammell, M. (Eds.), The sage handbook of political communication. (85-96). London, UK: Sage Publishing.

Carlson, E. (2017). Anti-colonial methodologies and practices for Settler Colonial Studies. Settler Colonial Studies, 7(4), 496-517.

Cecco, L. (2018, September 26). Canadian MP says Trudeau 'doesn't give a fuck' about indigenous rights. The Guardian. Retrieved from https://www.theguardian.com/world/2018/sep/26/trudeau-romeo-saganash-indigenousrights-parliament.

Clark, T., de Costa, R., \& Maddison, S. (2016). Non-Indigenous people and the limits of settler colonial reconciliation. In Maddison, S., Clark T., \& de Costa, R. (Eds.), The limits of settler colonial reconciliation: Non-Indigenous people and the responsibility to engage (introduction). Singapore, Singapore: Springer Nature. 
Coburn, V. (2017, September 6). The Royal Commission on Aboriginal Peoples recommended splitting up the Indigenous Affairs department 20 years ago. The context today is much different. Policy Options. Retrieved from http://policyoptions.irpp.org/magazines/september-2017/the-dismantling-of-indigenousand-northern-affairs-canada/

The Constitution Act. (1867). Government of Canada. Retrieved from https://lawslois.justice.gc.ca/eng/Const/

Corntassel, J. (2008). Towards sustainable self-determination: Rethinking the contemporary Indigenous-rights discourse. Alternatives, 33, 105-132.

Coulthard, G. S. (2014). Red skin, white masks: Rejecting the colonial politics of recognition. Minneapolis, MN: University of Minnesota Press.

Crosby, A. \& Monaghan, J. (2012). Settler governmentality in Canada and the Algonquins of Barriere Lake. Security Dialogue, 43(5), 2012, 421-438.

Crown-Indigenous Relations and Northern Affairs Canada (CIRNAC). (2015, January 12). Specific claims: Ongoing negotiations. Government of Canada. Retrieved from https://www.rcaanc-cirnac.gc.ca/eng/1100100030291/1539617582343.

Culhane, D. (1998). The pleasure of the Crown: Anthropology, law and First Nations. Burnaby: Talonbooks.

Davis, L., Hiller, C., James, C., Lloyd, K., Nasca, T., \& Taylor, S. (2017) Complicated pathways: Settler Canadians learning to re/frame themselves and their relationships with Indigenous peoples. Settler Colonial Studies, 7(4), 398-414.

Denis, J. S. \& Bailey, K. A. (2016). 'You can't have reconciliation without justice': How nonIndigenous participants in Canada's truth and reconciliation process understand their roles and goals. In Maddison, S., Clark T., \& de Costa, R. (Eds.), The limits of settler colonial reconciliation: Non-Indigenous people and the responsibility to engage (chapter 9). Singapore, Singapore: Springer Nature.

Department of Indian Affairs and Northern Development (DIAND). (2000, July 19). Comprehensive claims policy and status of claims. Government of Canada Publications. Retrieved from http://publications.gc.ca/collections/Collection/R32-221-2000E.pdf.

Derworiz, C. E. (2018). Federal departments of Indigenous and Northern Affairs. The Canadian Encyclopedia. Retrieved from https://www.thecanadianencyclopedia.ca/en/article/aboriginal-affairs-and-northerndevelopment-canada

Dhamoon, R. (2009). Identity/Difference politics: How difference is produced, and why it matters. Vancouver, BC: UBC Press.

Dhillon, J. (2017). Prairie rising: Indigenous youth, decolonization, and the politics of intervention. Toronto, ON: University of Toronto Press.

Diabo, R. (2013, January 10). Harper launches major First Nations termination plan. Socialist Project. Retrieved from https://socialistproject.ca/2013/01/b756/. 
Dickson, J. (2018). By law or in justice: The Indian Specific Claims Commission and the struggle for Indigenous justice. Vancouver, BC: UBC Press.

Doucet, A., \& Mauthner, N. (2005). Feminist Methodologies and Epistemology. In Bryant, C. D., \& Peck, D. L. (Eds.), 21st century sociology: A reference handbook. Nontraditional Perspectives (chapter 5). London, UK: Sage Publications.

Environics. (2008). 2008 National benchmark survey. Environics Research Group. Retrieved from http://www.nrsss.ca/IRSRC\%20TRC\%20National\%20Survey\%20Final\%20Report.pdf

Environics. (2016). Canadian public opinion on Aboriginal peoples. Environics Research Group. Retrieved from https://www.environicsinstitute.org/docs/default-source/projectdocuments/public-opinion-about-aboriginal-issues-in-canada-2016/finalreport.pdf?sfvrsn=30587aca_2.

Fischer, F. (2009). Democracy and expertise: Reorienting policy inquiry. New York City, NY: Oxford University Press.

George, R. (2017). Inclusion is just the Canadian word for assimilation: Self-determination and the reconciliation paradigm in Canada. In Ladner, K. L, \& Tait, M. J. (Eds.), Surviving Canada: Indigenous peoples celebrate 150 years of betrayal (chapter 6). Winnipeg, MB: ARP Books.

Grbich, C. (2013). Qualitative data analysis: An introduction (2nd ed.). London, UK: Sage Publications.

Harding, R. (2005). The media, Aboriginal people and common sense. Canadian Journal of Native Studies, 25(1), 311-336.

Harding, R. (2017). Controlling land: Historical representations of news discourse in B.C. American Indian Culture and Research Journal, 41(2), 65-92.

Harp, R. (2016). Foreword. In Perry A. (Ed.), Aqueduct. Winnipeg, MB: ARP Books.

Henderson, J. S. (2010). Constitutional vision and judicial commitment: Aboriginal and treaty rights in Canada. Australian Indigenous Law Review, 14(2), 24-48.

Henderson, J., \& Wakeham, P. (2013). Reconciling Canada: Critical perspectives on the culture of redress. Toronto, ON: University of Toronto Press.

Hiller, C. (2017). Tracing the spirals of unsettlement: Euro-Canadian narratives of coming to grips with Indigenous sovereignty, title, and rights. Settler Colonial Studies, 7(4), 415440.

Indigenous and Northern Affairs Canada (INAC). (2011). Evaluation of the Federal Government's Implementation of Self-Government and Self-Government Agreements. Government of Canada. Retrieved from https://www.aadncaandc.gc.ca/eng/1325102789963/1325102827484.

Irlbacher-Fox, S. (2009). Finding Dahshaa: Self-government, social suffering, and Aboriginal policy in Canada. Vancouver: UBC Press. 
James, M. (2017). Changing the subject: The TRC, its national events, and the displacement of substantive reconciliation in Canadian media representations. Journal of Canadian Studies, 51(2), 362-397.

Jody Wilson-Raybould's opening statement at justice committee: Full transcript. (2019, February 27). Maclean's. Retrieved from https:/www.macleans.ca/

Jung, C. (2019). The First Nations Land Management Act: Twenty years of reconciliation. American Review of Canadian Studies, 49(2), 247 -261.

Katz, E. \& Katz, R. (2016). Revisiting the origin of the administrative versus critical research debate. Journal of Information Policy, 6, 4-12.

King, H. \& Lee, E. V. (2015, December 15). The truth is there. But reconciliation is deeply complicated. The Globe and Mail. Retrieved from https://www.theglobeandmail.com/opinion/the-truth-is-there-but-reconciliation-is-deeplycomplicated/article27759105/

Ladner, K. (2018). Proceed with caution: Reflections on resurgence and reconciliation. In Asch, M., Borrows, J., \& Tully, J. (Eds.), Resurgence and reconciliation: Indigenous-settler relations and Earth teachings (chapter 8). Toronto, ON: University of Toronto Press.

Lawrence, B. (2012). Fractured homeland: Federal recognition and Algonquin identity in Ontario. Vancouver: UBC Press

Lee, E. (2016, March 1). Reconciling in the apocalypse. Canadian Centre for Policy Alternatives. Retrieved from https://www.policyalternatives.ca/publications/monitor/reconciling-apocalypse

Lemke, T. (2002). Foucault, governmentality, and critique. Rethinking Marxism, 14(3) 49-64.

Mackey, E. (2013). The apologizer's apology. In Henderson, J, \& Wakeham, P. (Eds.), Reconciling Canada: Critical perspectives on the culture of redress (chapter 2). Toronto, ON: University of Toronto Press.

Macklem, P. (2001). Indigenous Difference and the Constitution of Canada. Toronto: University of Toronto Press.

Maddison, S. (2016). Recognise what? The limitations of settler colonial constitutional reform. Australian Journal of Political Science, 52(1), 3-18.

Mahoney, K. (2016). The roadblock to reconciliation: Canada's origin story is false. The Globe and Mail. Retrieved from https://www.theglobeandmail.com/opinion/the-roadblock-toreconciliation-canadas-origin-story-is-false/article29951998/.

Maloney, R. (2019, March 28). Trudeau to Grassy Narrows protester: 'Thank you very much for your donation.' Huffington Post Canada. Retrieved from https://www.huffingtonpost.ca/2019/03/28/trudeau-grassy-narrows-protester-thank-youfor-your-donation-liberals_a_23701818/.

Manuel, A., \& Derrickson, R. (2017). The reconciliation manifesto: Recovering the land, rebuilding the economy. Toronto, ON: James Lorimer \& Company Ltd.

Marshall, T. (2019, January 28). Oka crisis. The Canadian Encyclopedia. Retrieved from https://www.thecanadianencyclopedia.ca/en/article/oka-crisis. 
McCrossan, M. (2015). Contaminating and collapsing Indigenous space: Judicial narratives of Canadian territoriality. Settler Colonial Studies, 5(1), 20-39.

McCrossan, M. (2013). Shifting judicial conceptions of 'reconciliation': Geographic commitments underpinning Aboriginal rights decisions. The Windsor Yearbook of Access to Justice, 31(2), 155-179.

McMahon, R. (2019, April 4). We become the stories we tell ourselves: How Indigenous storytelling will transform Canada. [Atkinson Lecture at Ryerson University] Ryerson School of Journalism in the Faculty of Communication And Design.

Million, D. (2013). Therapeutic nations: Healing in an age of Indigenous human rights. Tucson, AZ: University of Arizona Press.

Minister of Crown-Indigenous Relations and Northern Affairs Mandate Letter. (2017). Mandate letters. Prime Minister of Canada. Retrieved from https://pm.gc.ca/en/mandateletters/minister-crown-indigenous-relations-and-northern-affairs-mandate-letter.

Moreton-Robinson, E. (2009). Introduction: Critical Indigenous theory. Cultural Studies Review, 15(2), 11-12.

Nadasdy, P. (2002). 'Property' and Aboriginal land claims in the Canadian sub-arctic: Some theoretical considerations. American Anthropologist, 104(1), 247-61.

Newhouse, D. R., \& Belanger, Y. D. (2001). Aboriginal Self-Government in Canada: A Review of Literature since 1960. Peterborough: Department of Native Studies, Trent University.

Newman, D. G. (2008). Reconciliation: Legal conception(s) and faces of justice. In Whyte, J. D. (Ed.), Moving toward Justice: Legal Traditions and Aboriginal Justice (chapter 4). Saskatoon, SK: Purich Publishing.

Ongoing negotiations. (2018, May 23). Treaties, agreements and negotiations. Crown-Indigenous Relations and Northern Affairs Canada. Retrieved from https:/www.rcaanccirnac.gc.ca/eng/1100100030285/1529354158736.

Pasternak, S. (2017). Grounded authority: The Algonquins of Barriere Lake against the State. Minneapolis, MN: University of Minnesota Press.

Regan, P. (2018). Reconciliation and resurgence: Reflections on the TRC Final Report. In Asch, M., Borrows, J., \& Tully, J. (Eds.), Resurgence and reconciliation: Indigenous-settler relations and Earth teachings (chapter 6). Toronto, ON: University of Toronto Press.

Regan, P. (2010). Unsettling the settler within: Indian Residential Schools, truth telling and reconciliation in Canada. Vancouver, BC: UBC Press.

Rifkin, M. (2013) Settler common sense. Settler Colonial Studies, 3(3-4), 322-340.

Royal Commission on Aboriginal Peoples (RCAP). (1996). Report of the Royal Commission on Aboriginal Peoples. Ottawa: Minister of Supply and Services Canada.

$R$ v. Gladstone. (1996). SCR 723.

$R$ v. Van der Peet. (1996). SCR 507. 
Salee, D., \& Levesque, C. (2010). Representing Aboriginal self-government and First Nations/state relations: Political agency and the management of the boreal forest in Eeyou Istchee. International Journal of Canadian Studies, 41(1), p. 99-135.

Samson, C. (2016). Canada's strategy of dispossession: Aboriginal land and rights cessions in Comprehensive Land Claims. Canadian Journal of Law and Society, 31(1), 87-110.

Schedule N. (2008). Mandate for the Truth and Reconciliation Commission. Indian Residential Schools Settlement Agreement. Retrieved from http://rc.ca/assets/pdf/vSCHEDULE_N_EN.pdf.

Self-government. (2018, July 12). Treaties, agreements and negotiations. Crown-Indigenous Relations and Northern Affairs Canada. Retrieved from https://www.rcaanccirnac.gc.ca/eng/1100100032275/1529354547314.

Short, D. (2008). Reconciliation and colonial power: Indigenous rights in Australia. London, UK: Routledge.

Simpson, A. (2016) The state is a man: Theresa Spence, Loretta Saunders and the gender of settler sovereignty. Theory \& Event, 19(4).

Simpson, L. B. (2011). Dancing on our turtle's back. Winnipeg, MB: ARP Books.

Simpson, L. B. (2017). As we have always done. Minneapolis, MN: University of Minnesota Press.

Simpson, L. B. (2016, March 5). Land and reconciliation: Having the right conversations. Electric City. Retrieved from www.electriccitymagazine.ca/2016/01/land-reconciliation/.

Slowey, G. (2000). Aboriginal self-government, extinguishment of title and the Canadian State: Effectively removing the 'Other'. Native Studies Review, 13(1) 1-17.

Smart, A. (2019, July 19). Canadians need to be patient, present, unconditional with reconciliation: Trudeau. CTV News. Retrieved from https://beta.ctvnews.ca/national/politics/2019/7/19/1_4515227.html.

Smith, L. T. (2012). Decolonizing methodologies: Research and Indigenous peoples. London, UK: Zed Books.

Strakosch, E. (2016). Beyond colonial completion: Arendt, settler colonialism and the end of politics. In Maddison, S., Clark, T., \& de Costa, R. (Eds.), The limits of settler colonial reconciliation (chapter 1). Singapore, Singapore: Springer Nature.

Strakosch, E. \& Macoun, A. (2012). The vanishing endpoint of settler colonialism. Arena Journal, 37/38, 40-62.

Stefanovich, O. (2019, October 4). Trudeau government seeks judicial review of tribunal decision to compensate First Nations kids. $C B C$ News. Retrieved from https://www.cbc.ca/news/politics/human-rights-tribunal-liberal-child-welfare-appeal1.5308897 .

Stuckey, M.E. (2018). Political Communication. In Allen, M. (Ed), The SAGE encyclopedia of communication research methods (1268-1271). London, UK: Sage Publishing.

The Government of Canada's approach to implementation of the inherent right and the negotiation of Aboriginal self-government. (2018, September 15). Self-government. 
Crown-Indigenous Relations and Northern Affairs Canada. Retrieved from https://www.rcaanc-cirnac.gc.ca/eng/1100100031843/1539869205136.

Tla'amin Nation implement treaty with B.C., Canada. (2016, April 5). CBC News. Retrieved from https://www.cbc.ca/news/canada/british-columbia/tlaamin-nation-treaty-finalized1.3521493 .

Toronto Purchase Specific Claim. (n.d.) Mississaugas of the New Credit First Nation. Retrieved from http://mncfn.ca/wp-content/uploads/2017/04/MNCFN-Toronto-Purchase-SpecificClaim-Arriving-at-an-Agreement.pdf.

Tuck, E., \& Yang, K. W. (2012) Decolonization is not a metaphor. Decolonization: Indigeneity, Education \& Society, 1(1), 1-40.

Tully, J. (2018). Reconciliation here on Earth. In Asch, M., Borrows, J., \& Tully, J. (Eds.), Resurgence and reconciliation: Indigenous-settler relations and Earth teachings (chapter 3). Toronto, ON: University of Toronto Press.

Tully, J. (1995). Strange multiplicity: Constitutionalism in the age of diversity. Cambridge: Cambridge University Press.

Turner, D. (2013). On the idea of reconciliation in contemporary Aboriginal politics. In Henderson, J, \& Wakeham, P. (Eds.), Reconciling Canada: Critical perspectives on the culture of redress (chapter 5). Toronto, ON: University of Toronto Press.

Volume 6. (2015). Canada's residential schools: Reconciliation. The final report of the Truth and Reconciliation Commission of Canada. Retrieved from http://www.trc.ca/assets/pdf/Volume_6_Reconciliation_English_Web.pdf.

Wallace, S. I. (2018, April 11). Williams Treaties. The Canadian Encyclopedia. Retrieved from https://www.thecanadianencyclopedia.ca/en/article/williams-treaties.

Wolfe, P. (2006). Settler colonialism and the elimination of the native. Journal of Genocide Research, 8(4), 387-409.

Wylie, H. (2017). Towards a genealogy of reconciliation in Canada. Journal of Canadian Studies, 51(3), 601-635. 